\title{
العامل النحوي \\ دراسة ابستمولوجية
}

$$
\text { د. سعاد كريدي كنداوي }
$$

جامعة القادية - كلية التربية - قسم اللغة العربية 


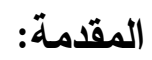

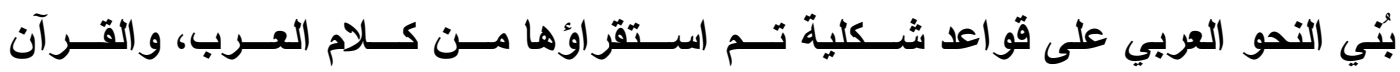

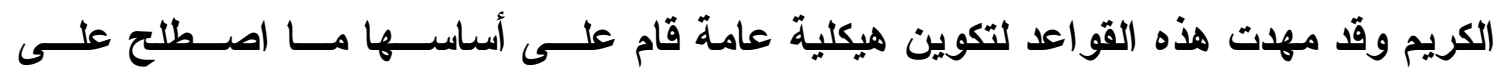

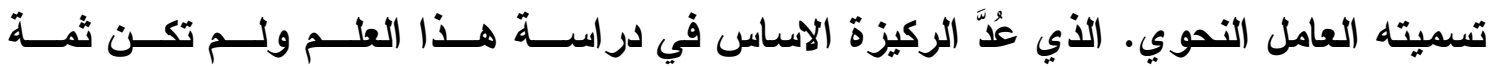

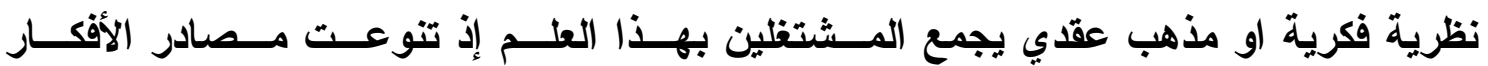

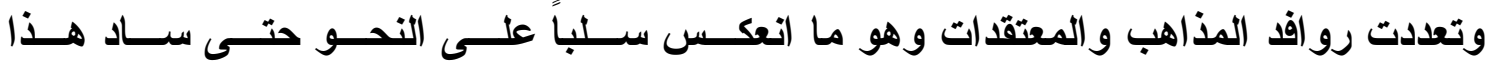

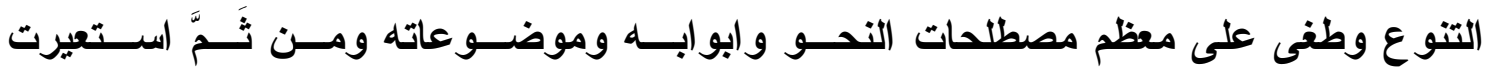

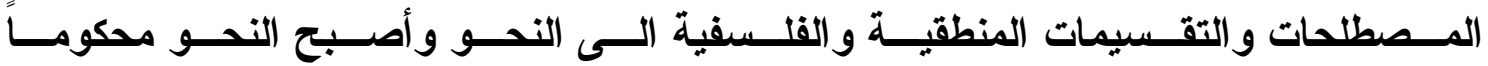
بمسلمات لا علاقة له بها سوى انها انعكاس فكري للمشتفلين به.

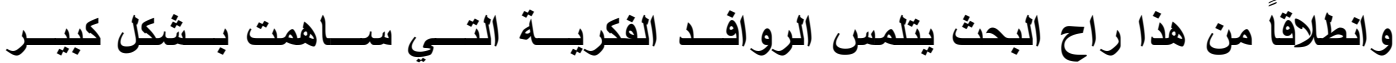

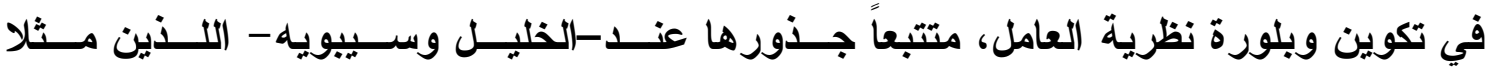

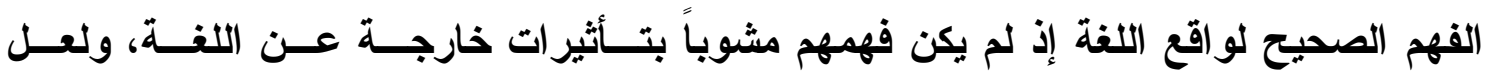

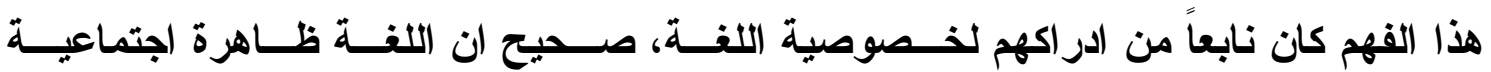

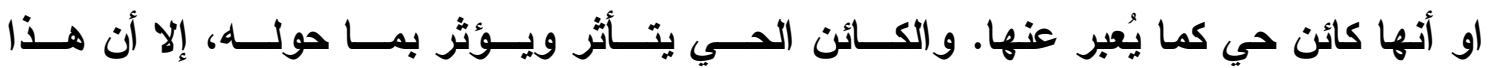

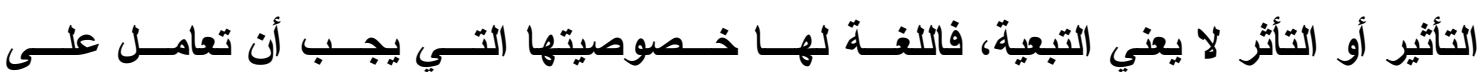
اساسها ومن ثمَّ لا بـ أن تنبني مصطلحات اللغة وقو اعدها على هذا الاساس.

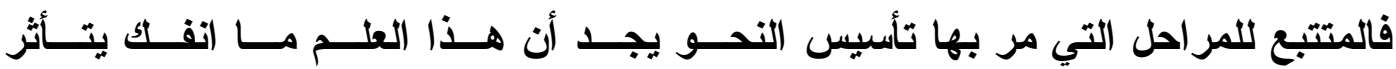

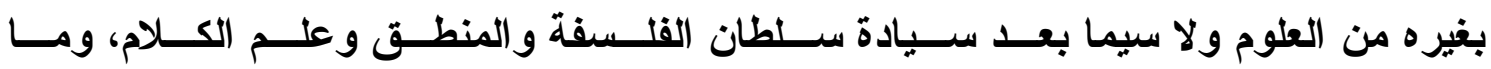

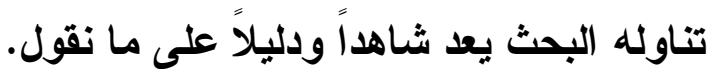

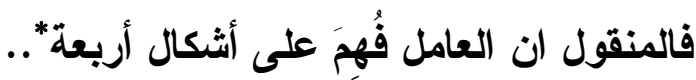

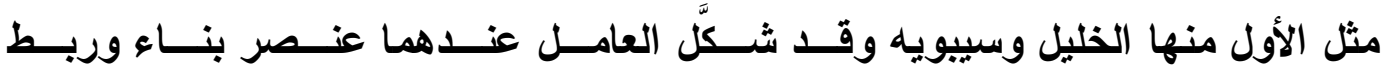

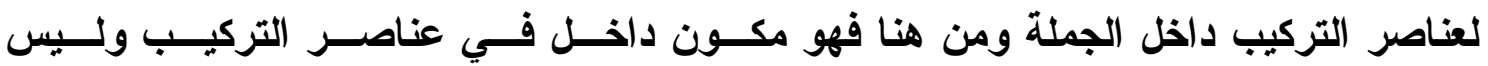

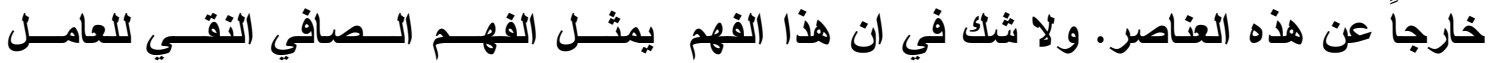
قبل ان يُخلط بمفاهيم و افكار لا علاقة للغة بها.

* وقد أقتضت طبيعة البحث ان يدمج بين الفهمين الاول و الثاني لتداظهما وصعوبة الفصل بينهما فكان العنوان الخليل وسيبويه ومن تلاهما من النحاة. 
ومثل الفهم الثاني عامة النحاة الخالفين للخليـلـل ســيبويه ولا ســيما اصـــاب المتــون

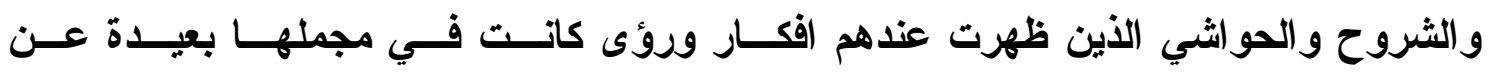

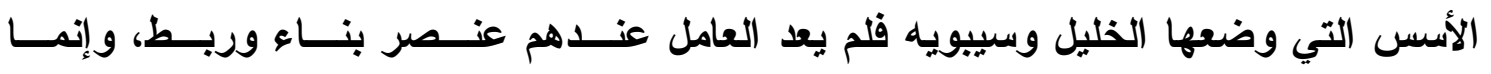

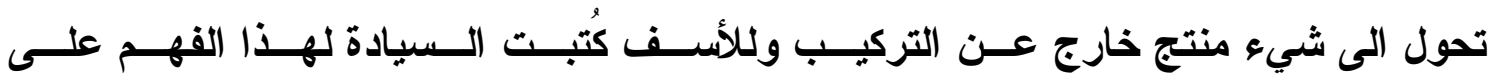

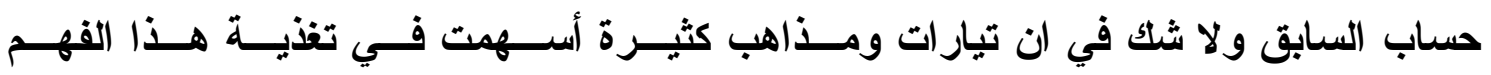
وتكوينه.

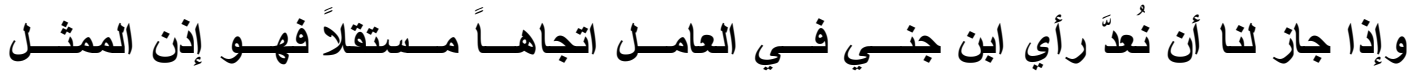

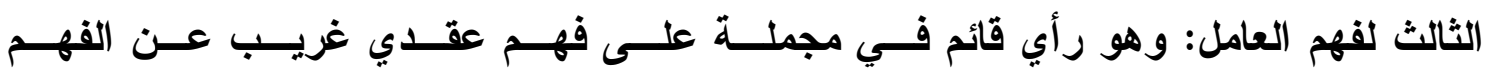

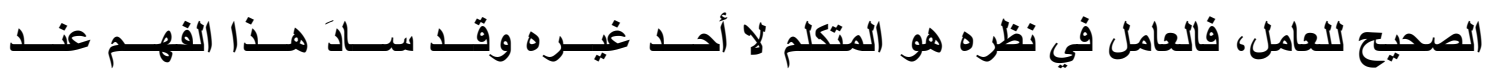

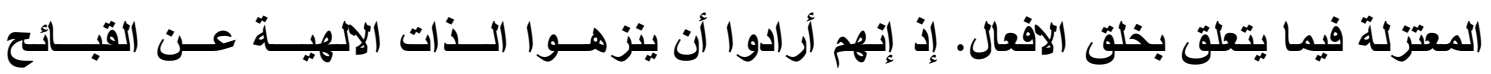

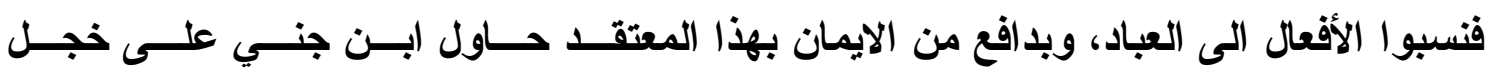
نقله الى النحو فكان مجال تطبيقه العامل النحوي.

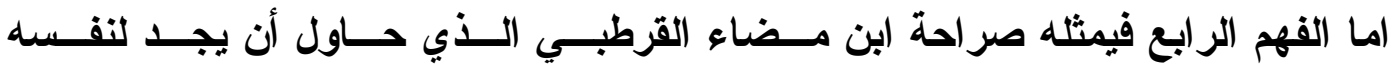

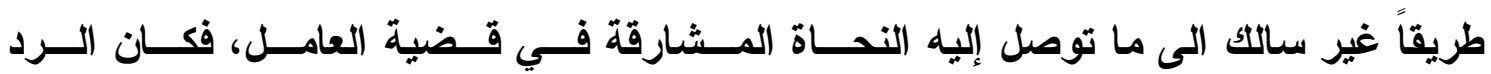

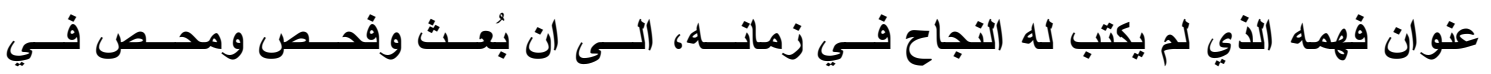
زمن غيره وهذا ما سيتضح لاحقاً إن شاء الله.

أولاً: الخليل (ت هV V هـ) وسيبويه (ت . 1 1 هـ) ومن تلاهما من النحاة:

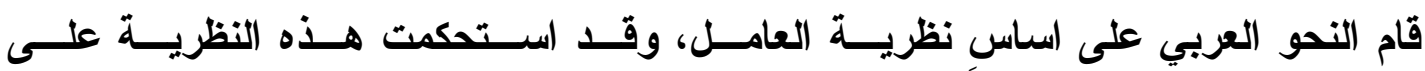

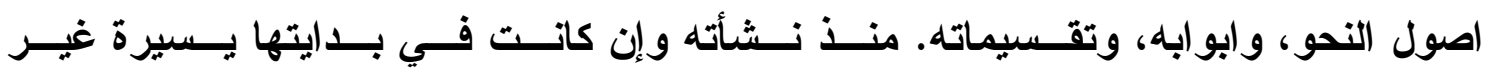

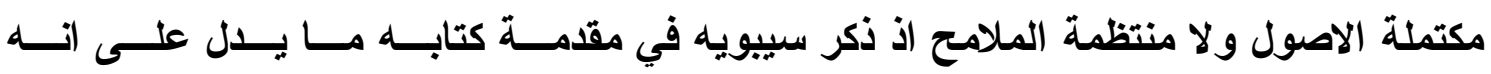

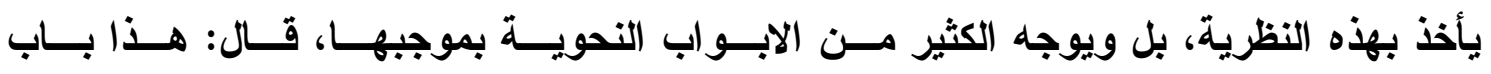

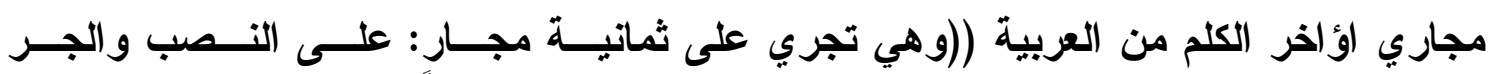

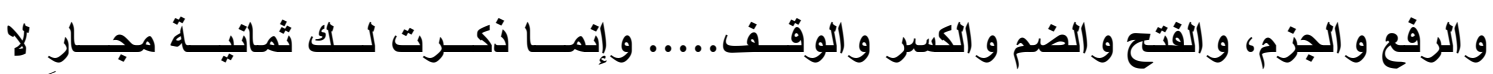

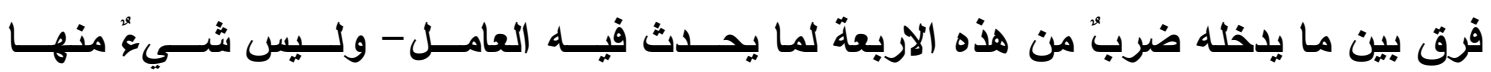

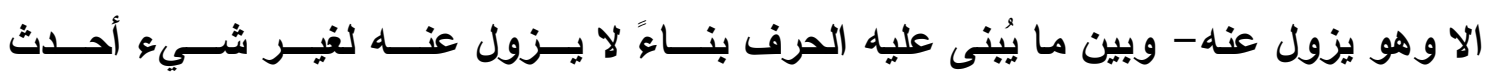




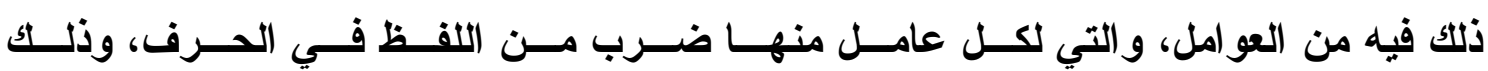

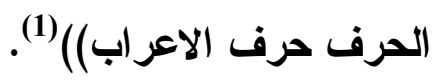

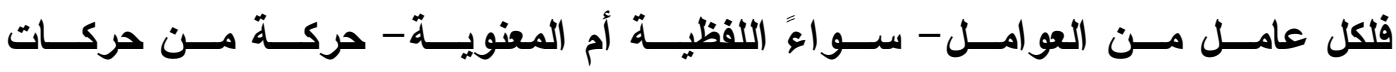

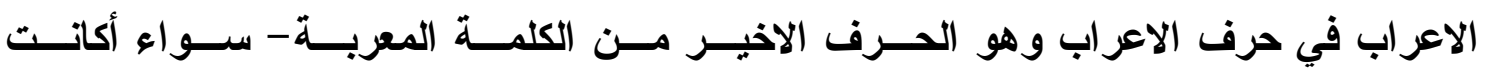
الكلمة اسماً ام فعلاً معرباً. وهذا النص يدعونا للتساؤل عن حقيقــة موقــف ســيبويه مــن العامـل، وعــن الأثــر الأي يتركه العامل فيما بعده.

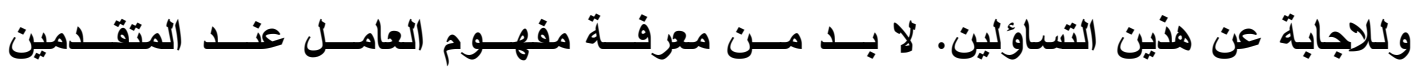

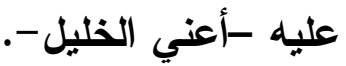

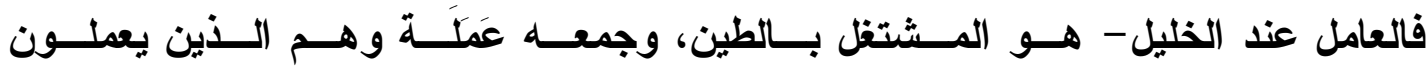

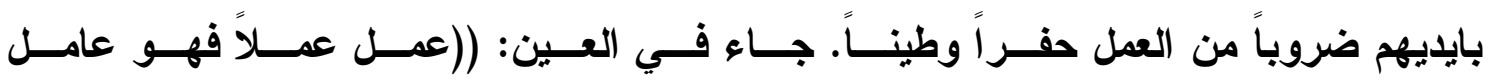

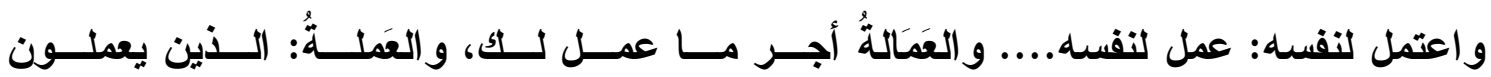

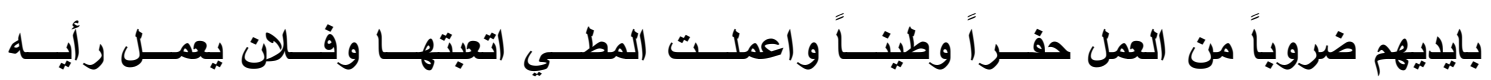
ورمحه وكلامه ونحوه عمل به و البَّنَُّ يستعمل اللبن إذا بنى به بناءً) (2).

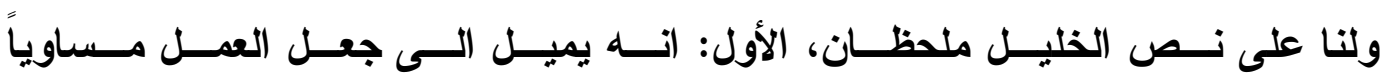

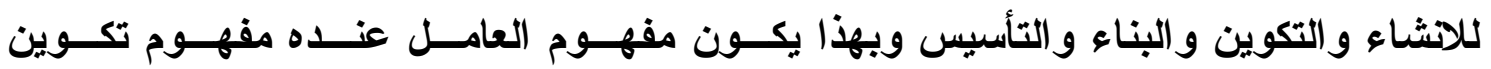

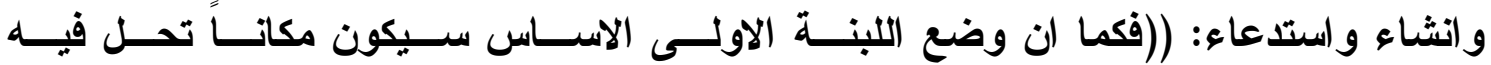

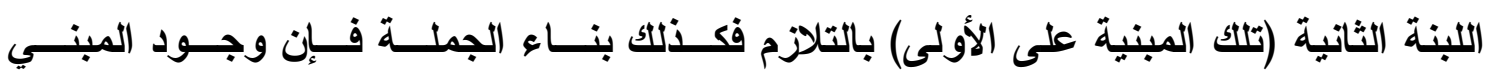

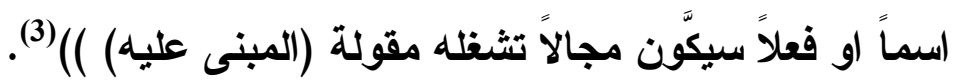

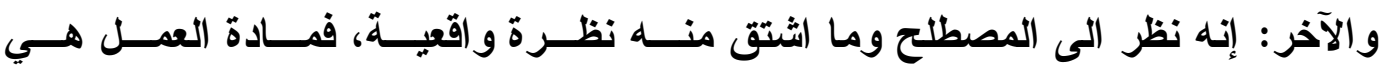

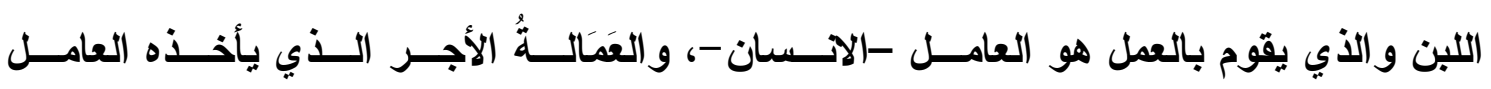

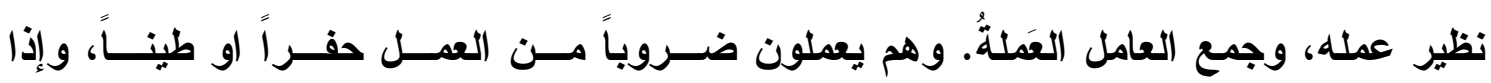

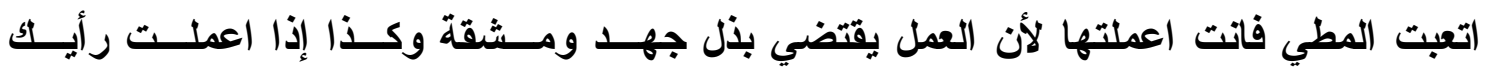

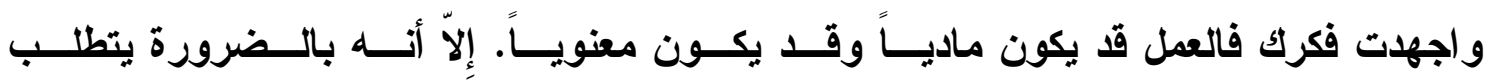

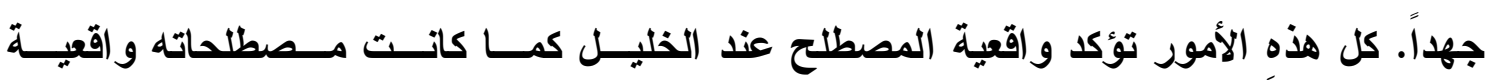

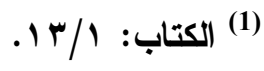

$$
\begin{aligned}
& \text { (2) العين: }
\end{aligned}
$$

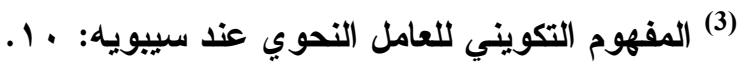




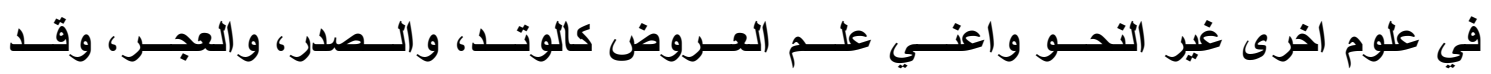

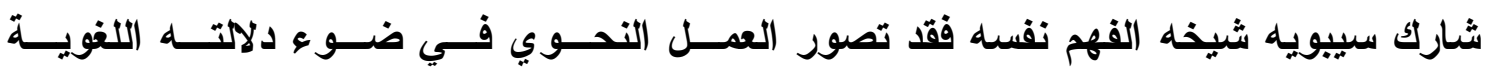

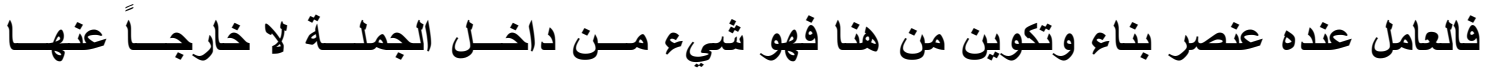

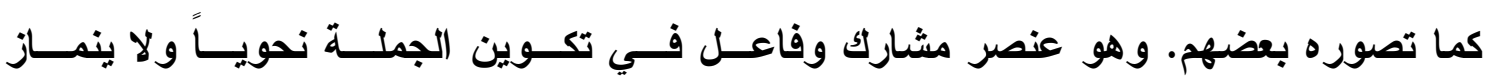

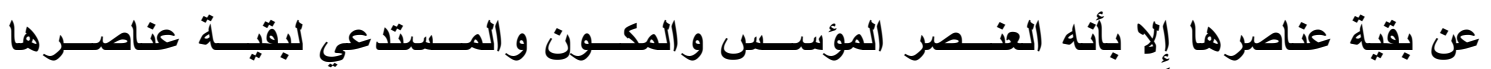

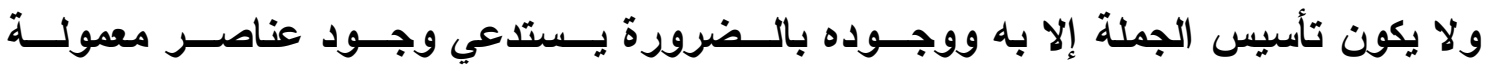
تختلف كماً تبعاً لاختلافه فهي محدودة إن كان المؤسس اسماً وتتسع إذا بأ كان فعلاً.

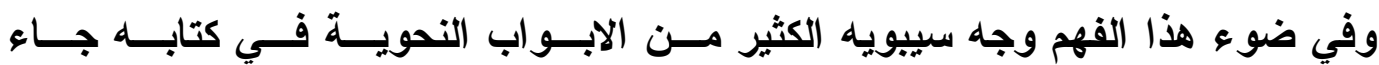

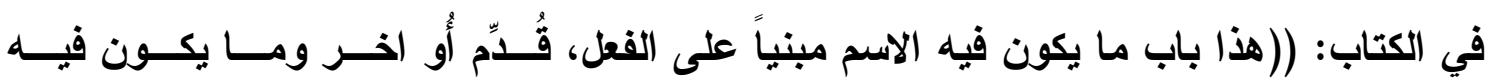

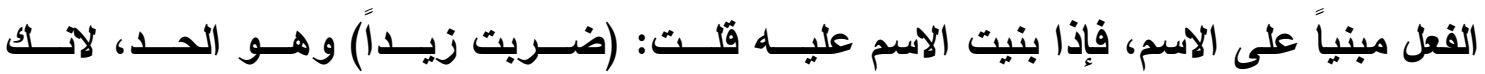
تريد ان تعمله وتحمل عليه الاسم)(1).

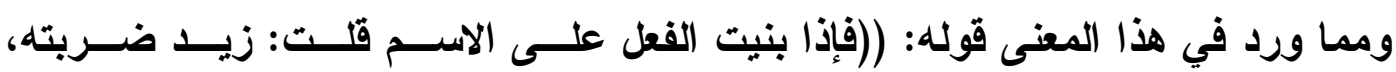

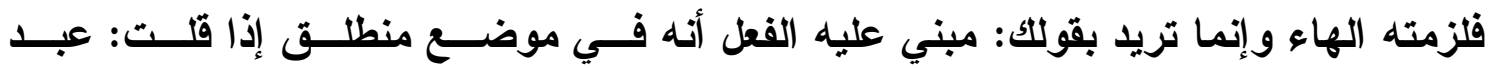

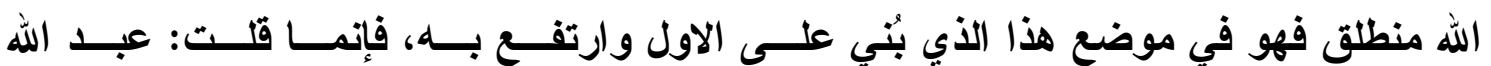

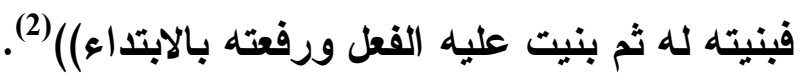

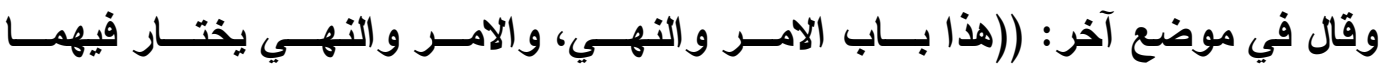

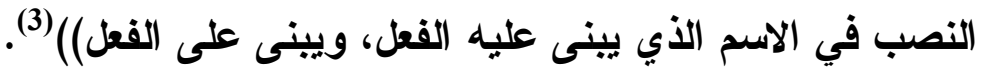

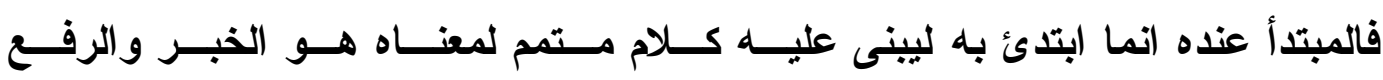

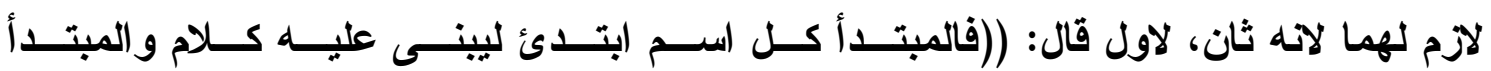

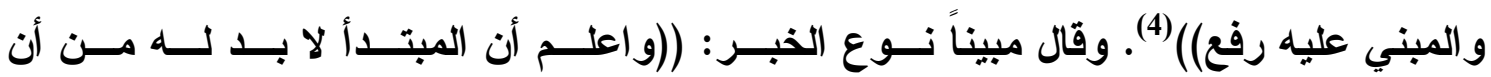

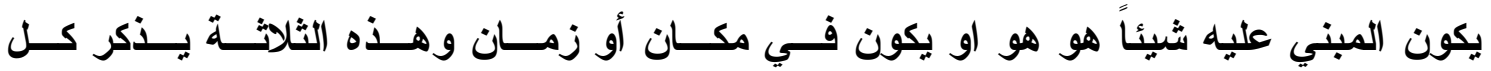

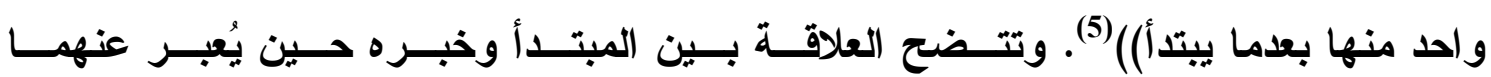

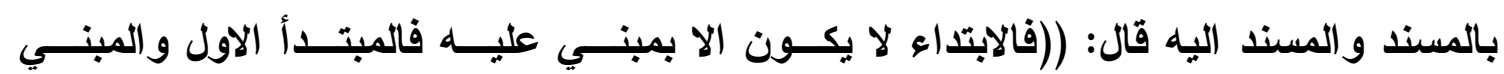

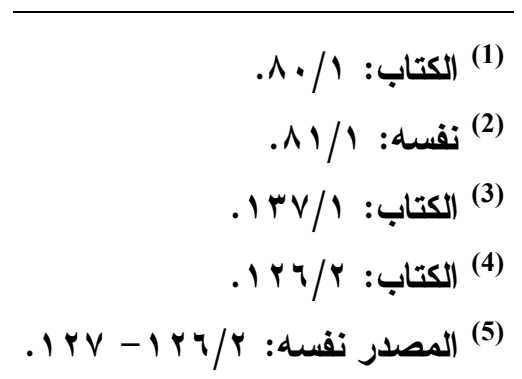




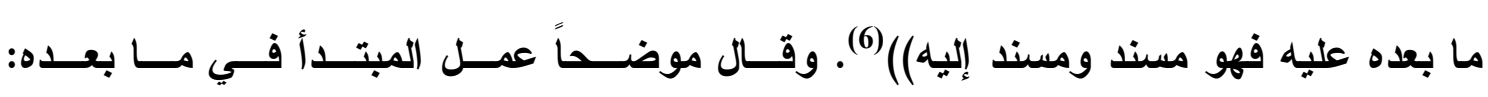

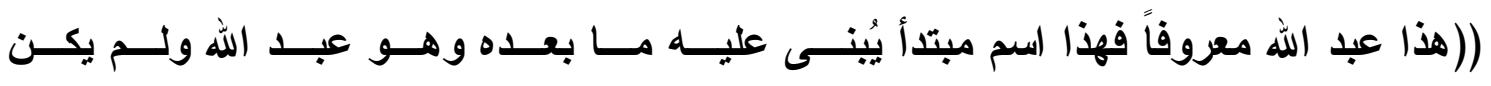

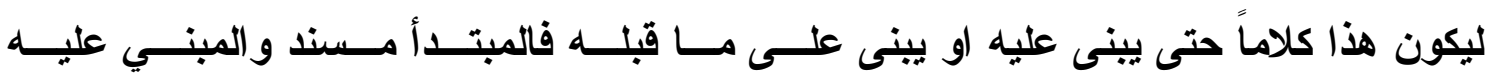

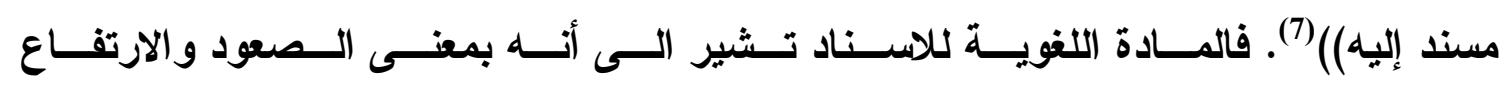

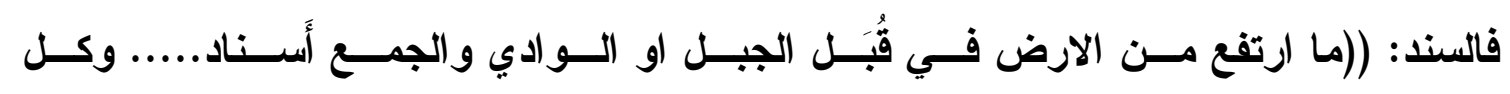

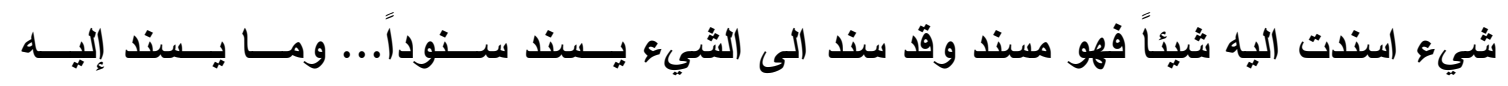

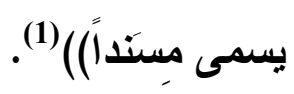

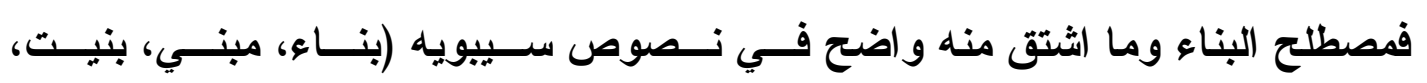

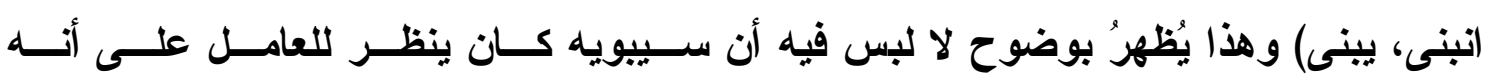

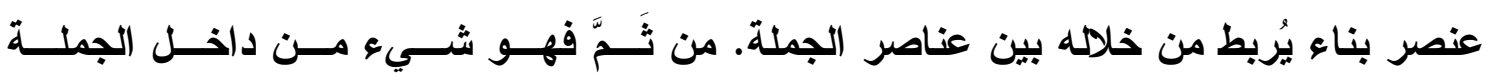

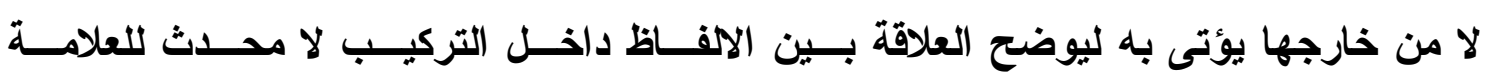

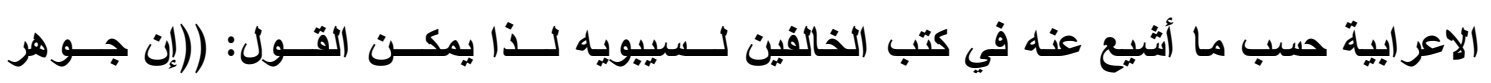

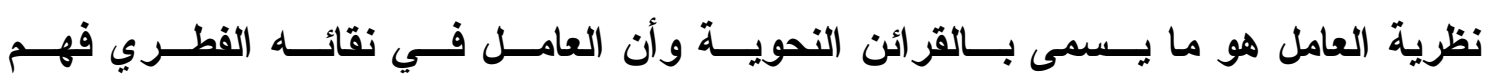

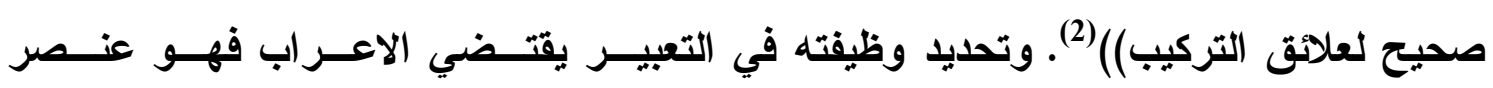

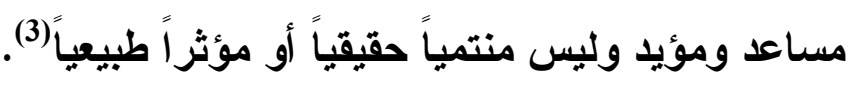

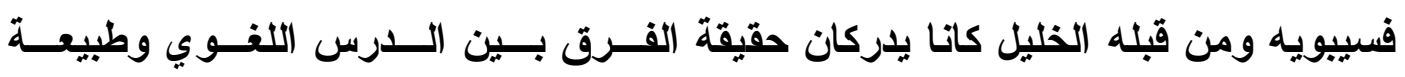

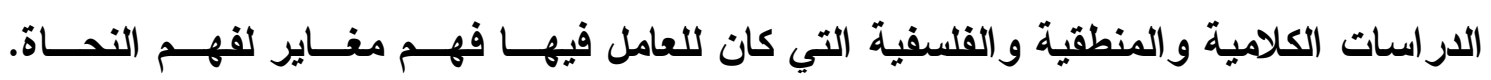

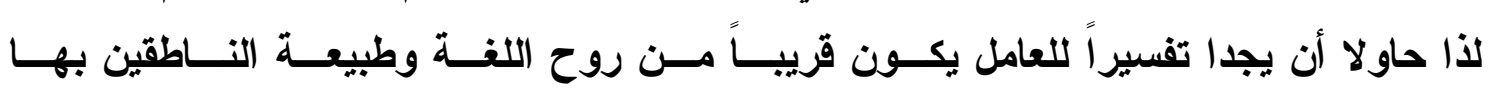
بعياً عن التأثير ات الخارجة عنها.

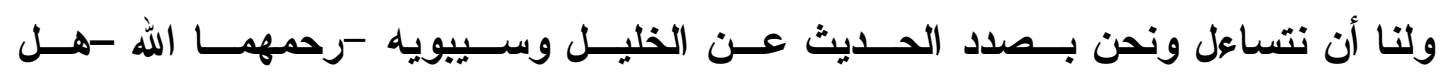

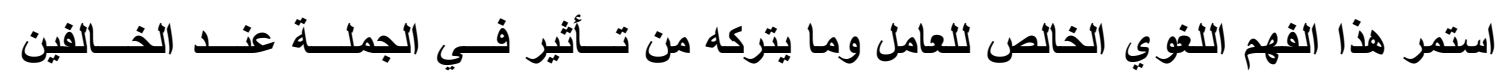

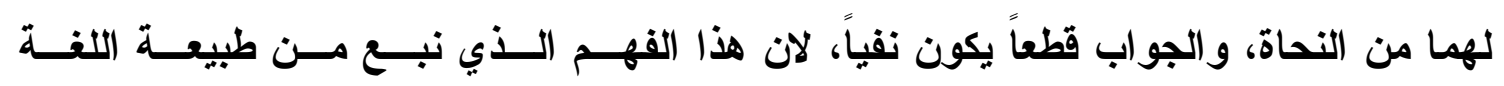

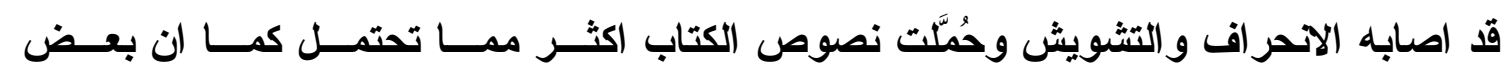

\author{
(6) (المصدر نفسه: (7)

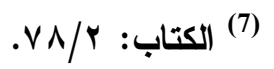

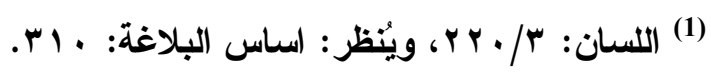

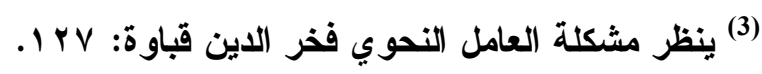

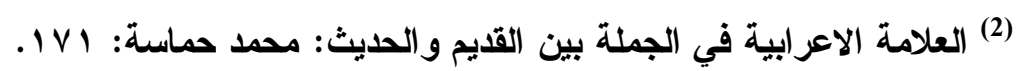




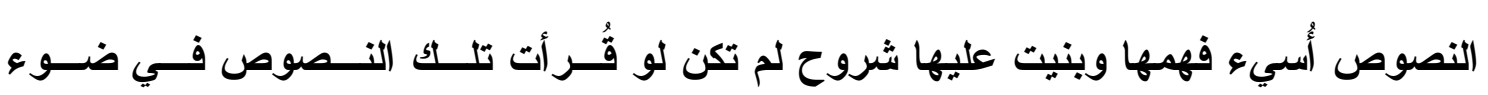

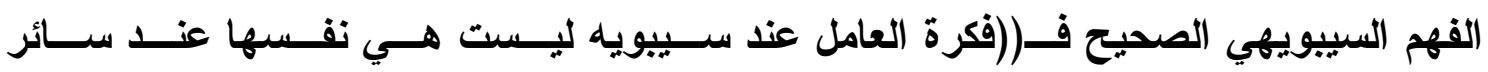

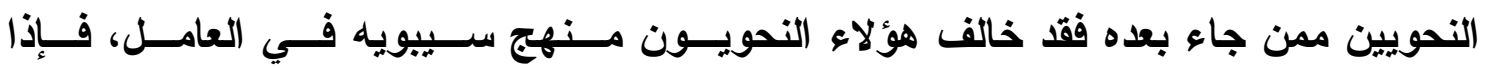

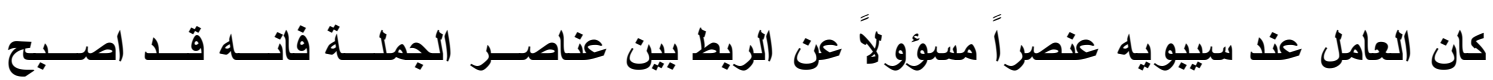

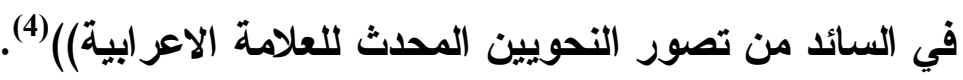

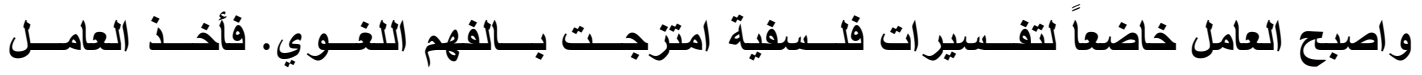

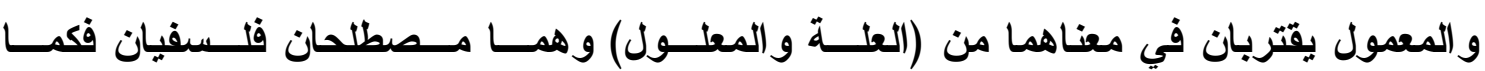

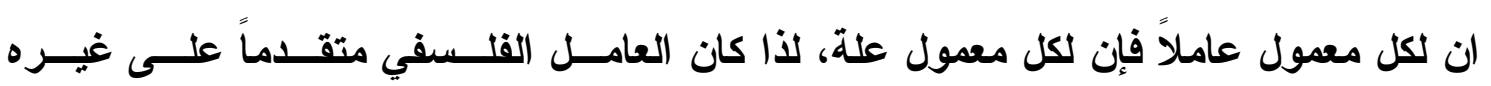

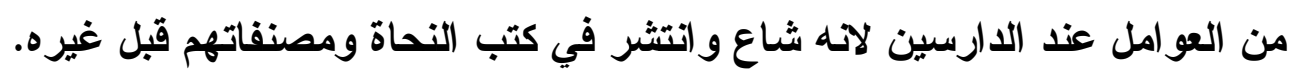

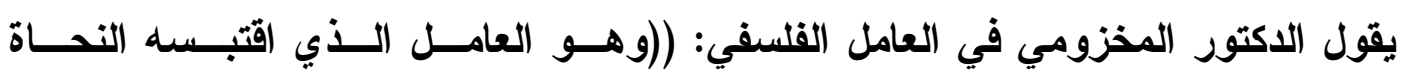

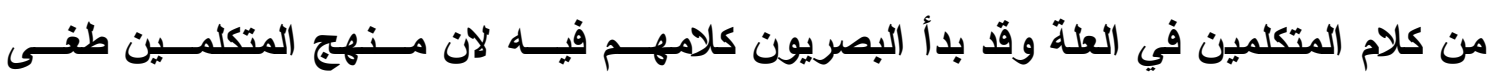

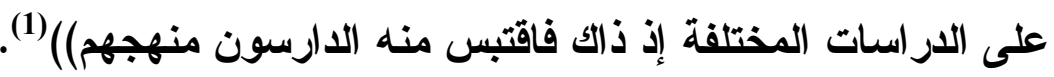

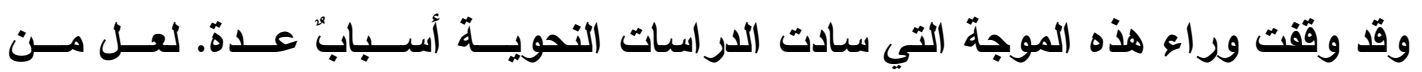

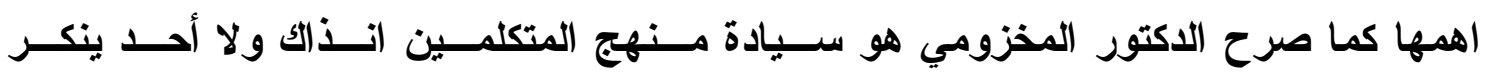

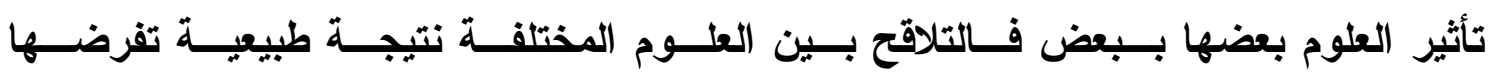

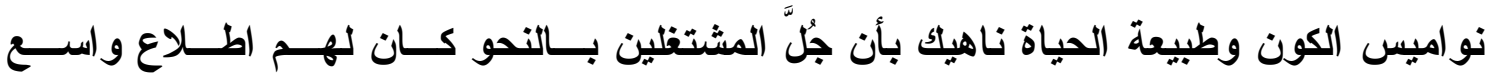

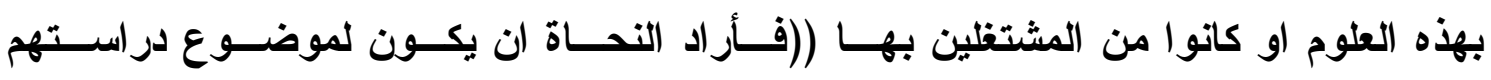

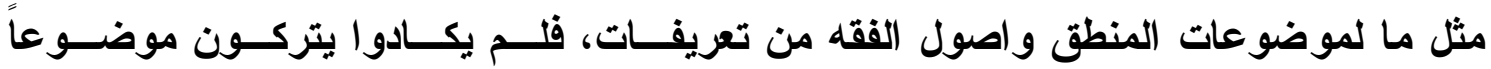

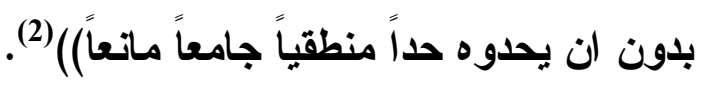

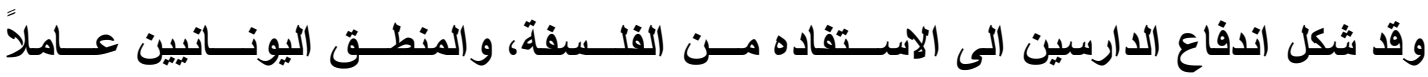

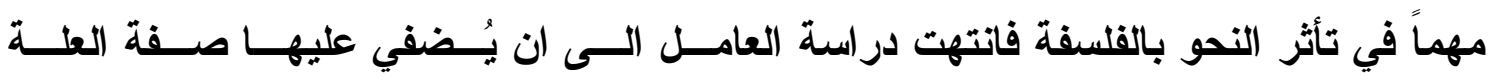

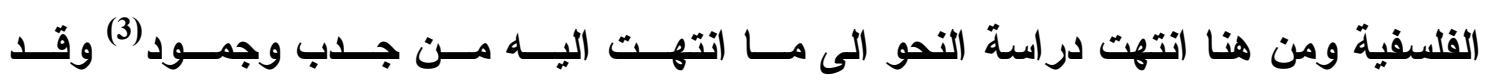

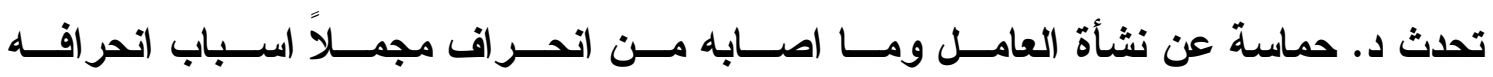

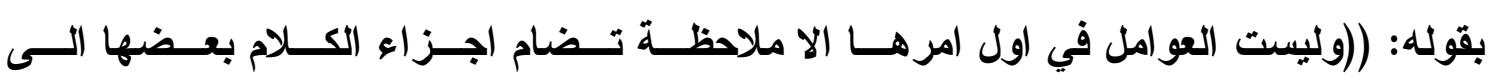

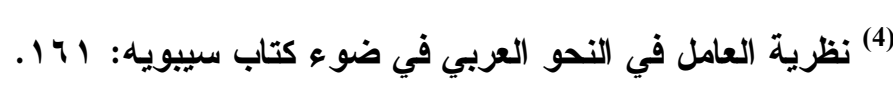

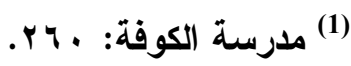

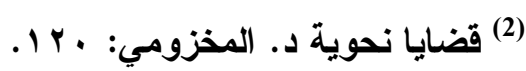

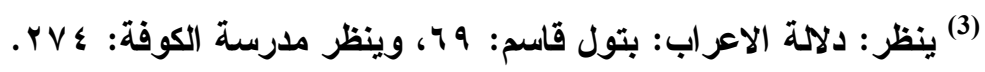




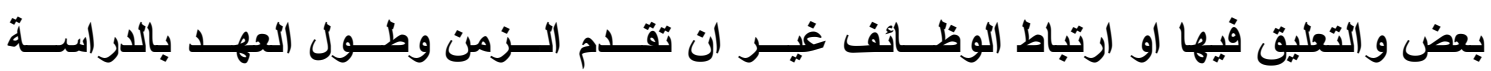

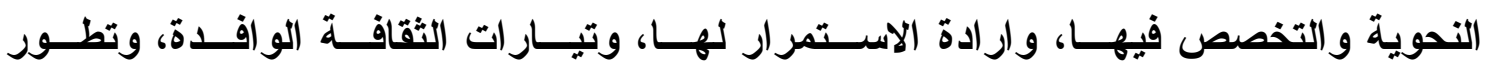

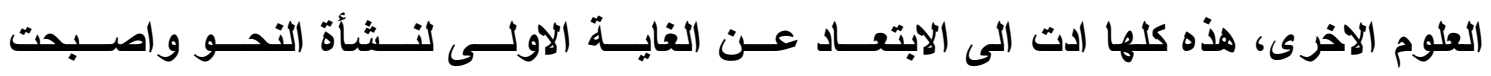

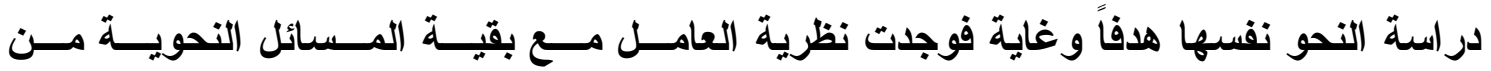

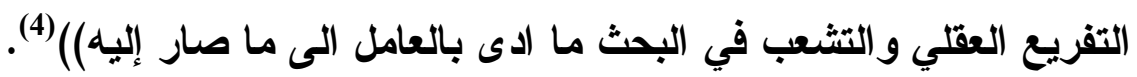

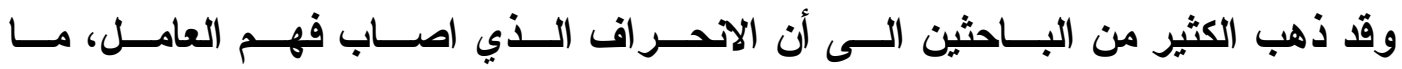

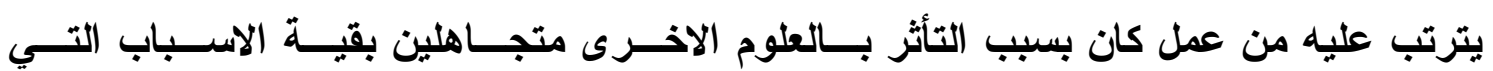
اثبتها د. حماسة.

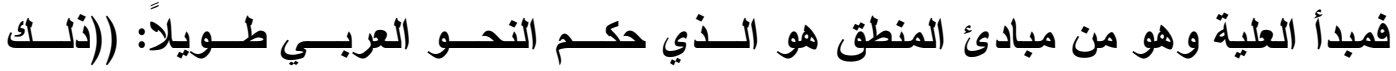

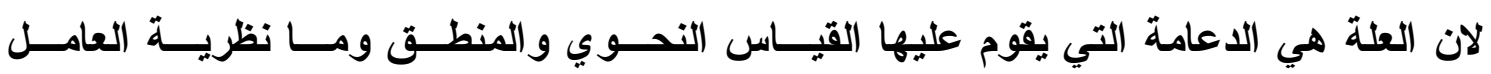

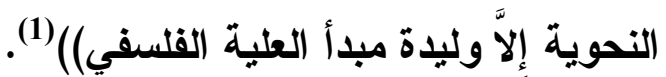

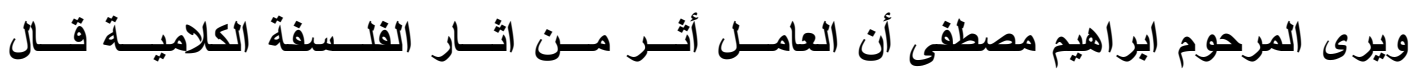

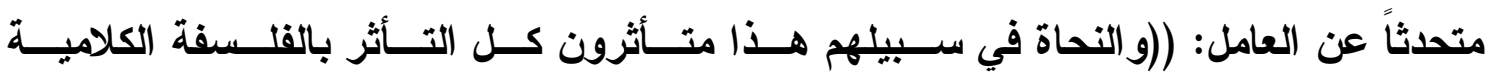

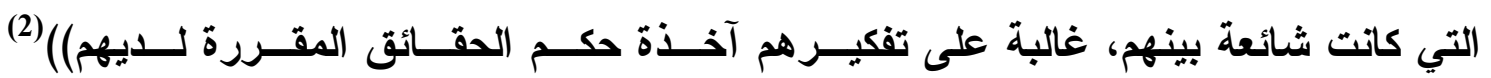
وقد ارتضى د. المخزومي هذا الر أي واخذ به.

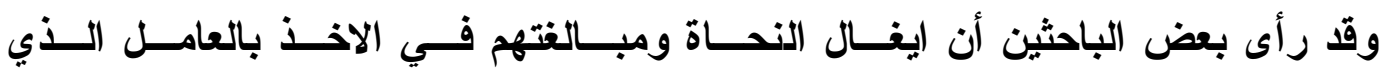

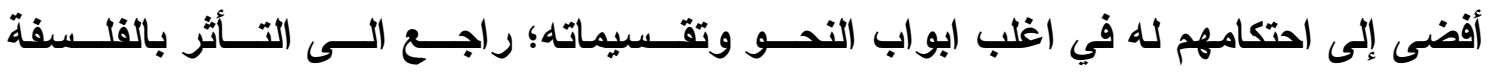

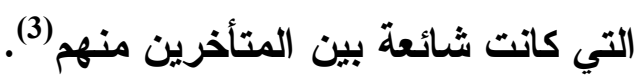

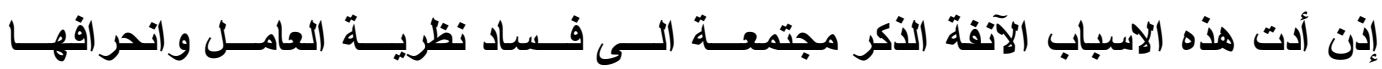

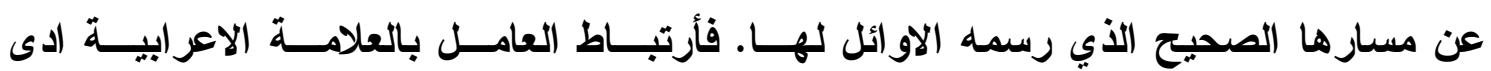

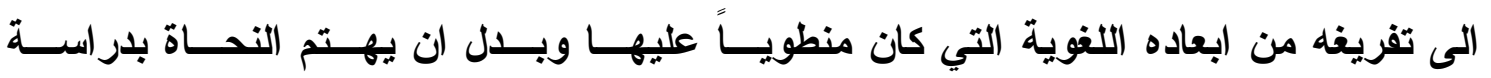

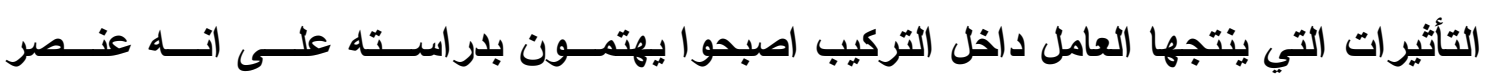

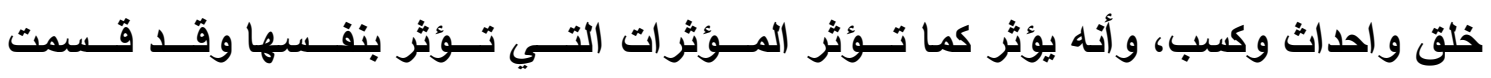

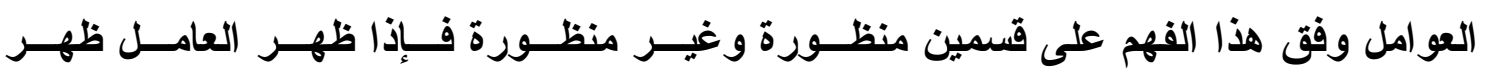

$$
\begin{aligned}
& \text { (4) العلامة الاعرابية: ل } 17 \text {. } 1 \text { (1) } \\
& \text { (1) في اللغة والادب: .0. }
\end{aligned}
$$

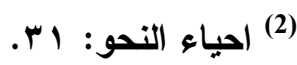

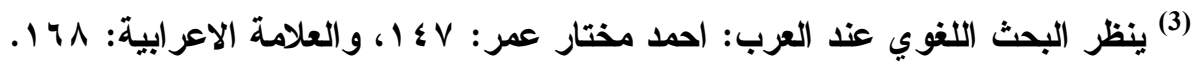




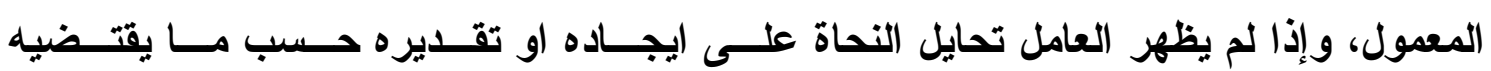

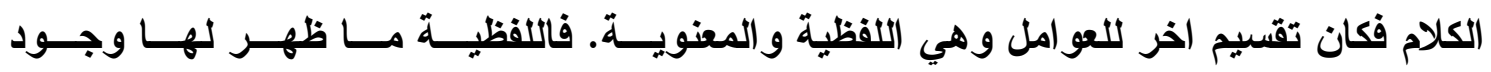

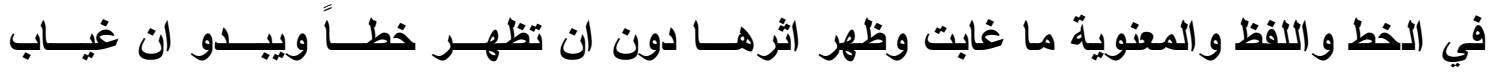

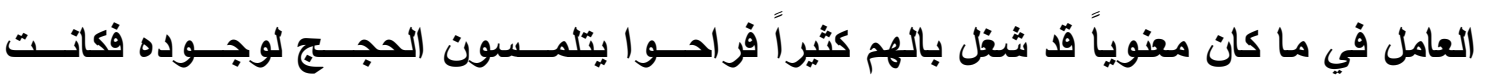
في اغلبها بعيدة عن روح اللغة قريبة من علل الفلاسفة.

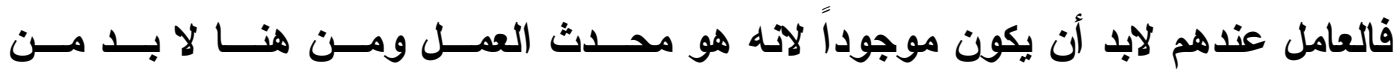

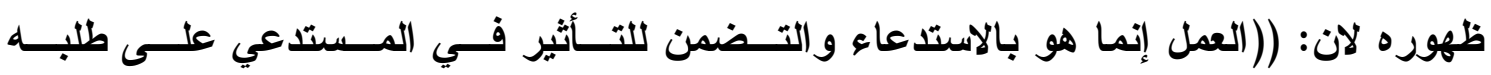

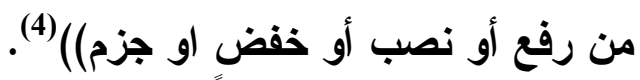

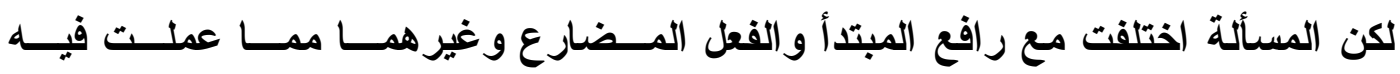

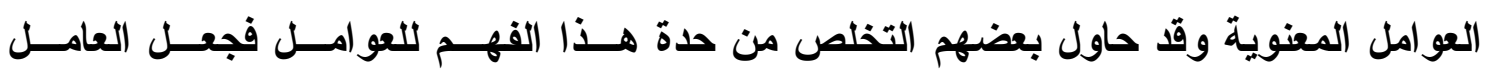

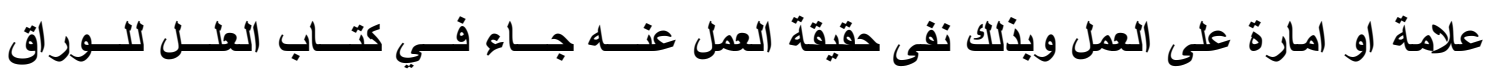

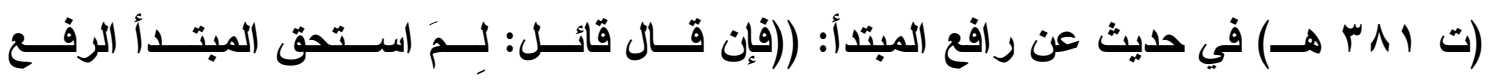

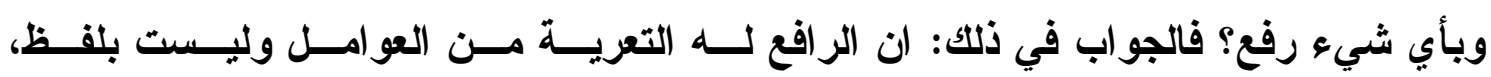

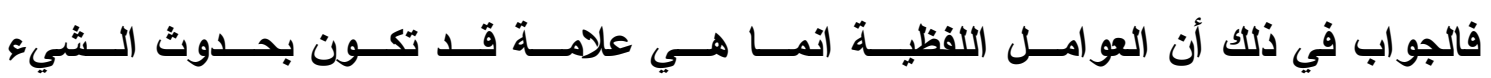

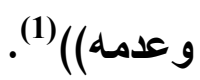

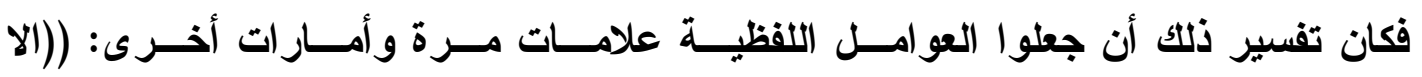

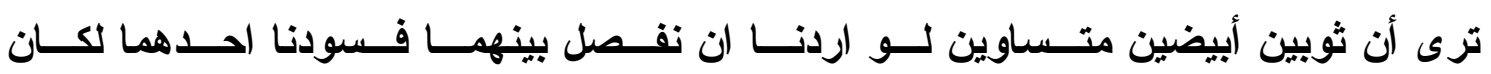

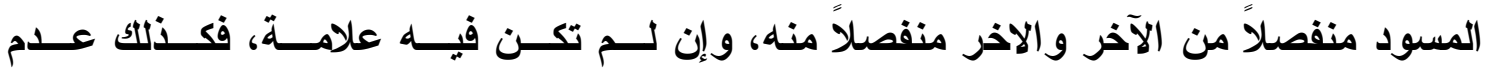

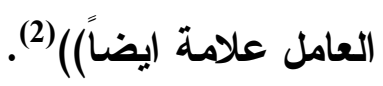

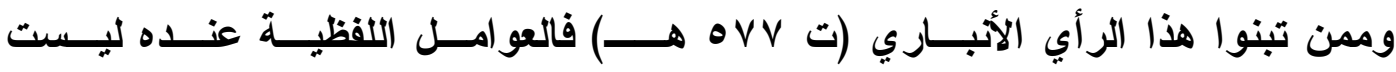

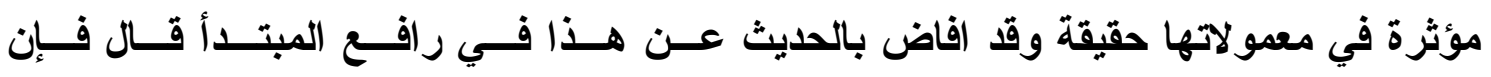

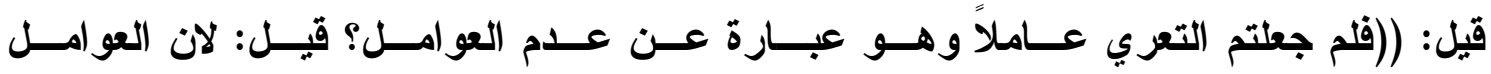

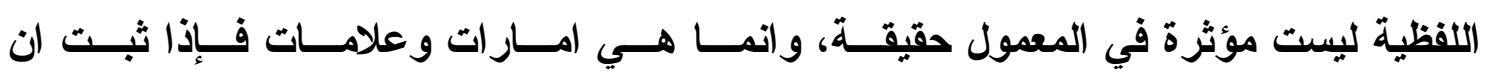

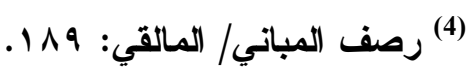

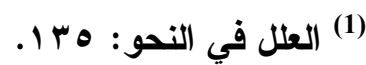

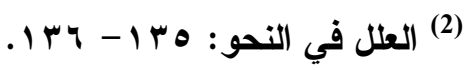




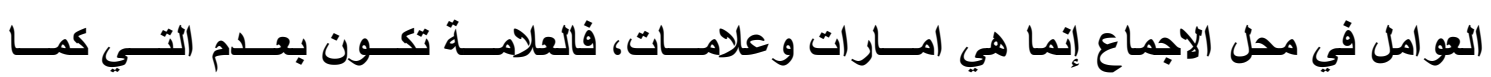

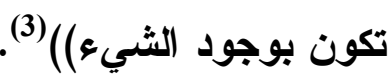

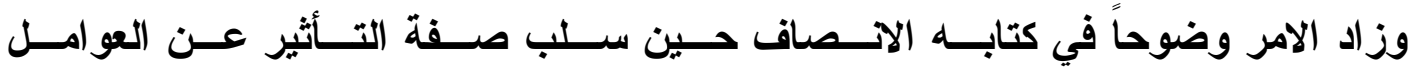

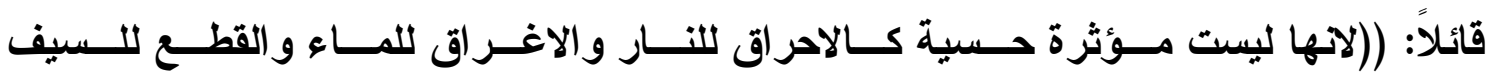

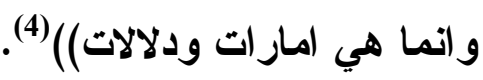

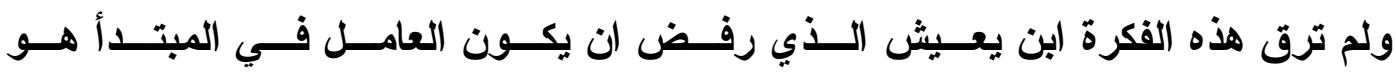

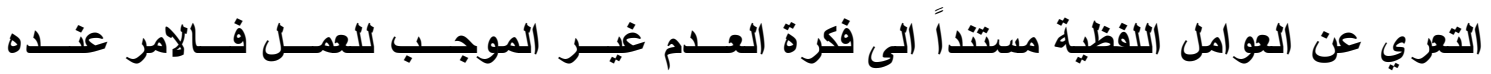

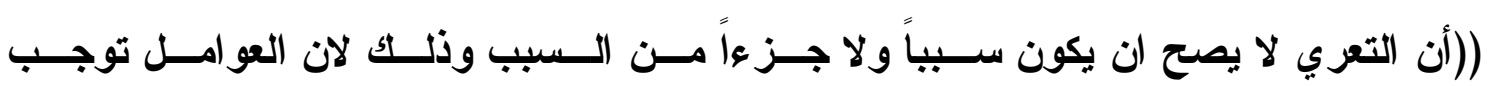

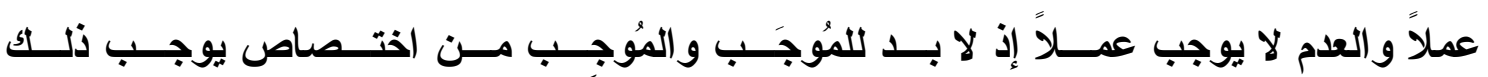
ونسبة العدم الى الاثياء كلها نسبة واحدة)) (5).

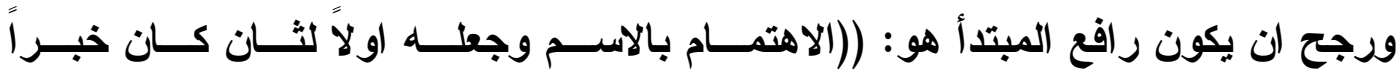

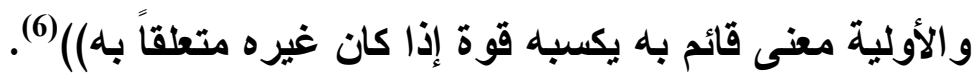

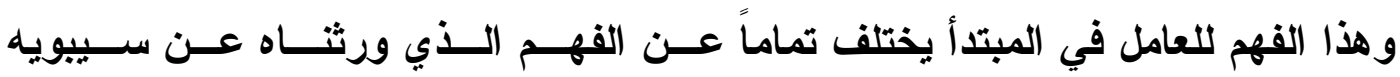

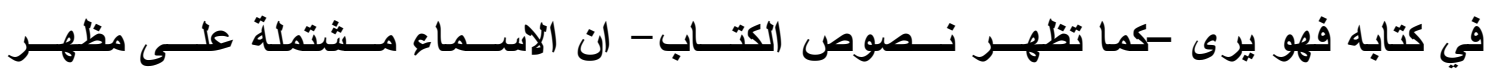

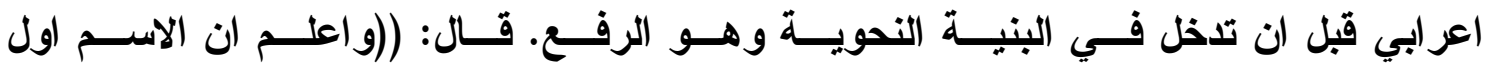

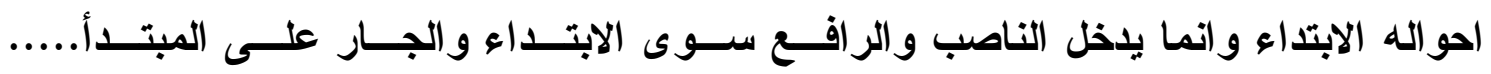

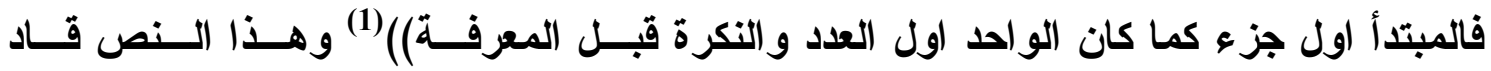

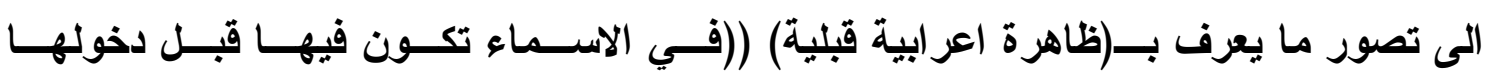

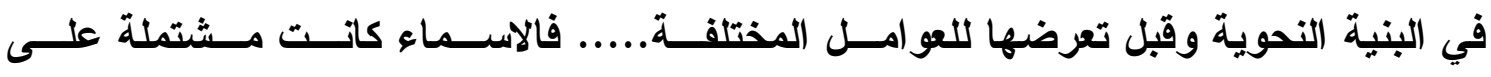

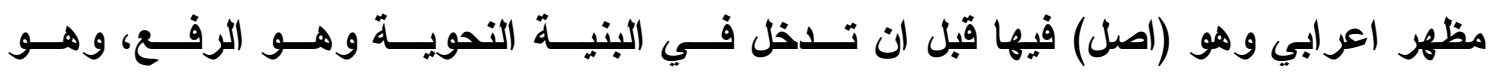
عنده ان لا يكون العامل داخل على تلك الاسماء بل سمة مقولية (صيلة فيها)) (2).

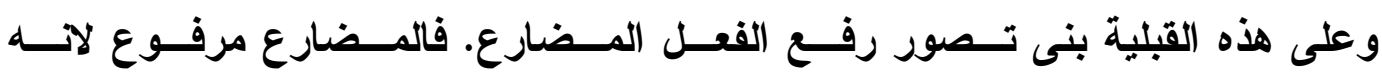

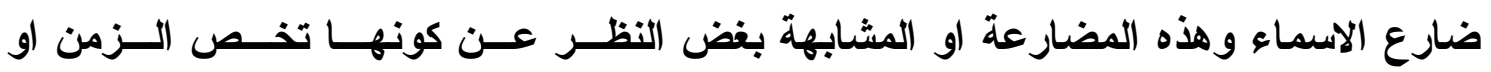

$$
\begin{aligned}
& \text { (3) (اسرار العربية: } 14 \text { (4) } 79 .
\end{aligned}
$$

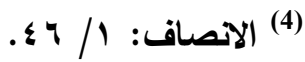

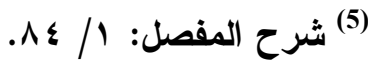

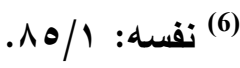

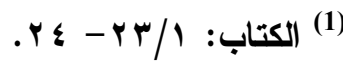

$$
\begin{aligned}
& \text { (2) المفهوم التكويني للعامل النحوي: V. V. }
\end{aligned}
$$




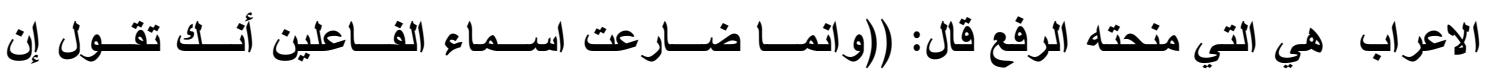

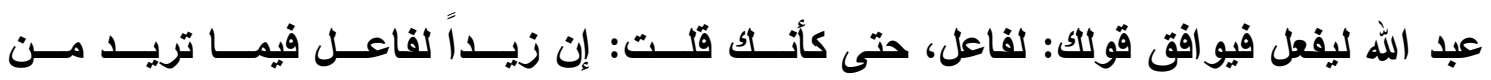
(المنى))

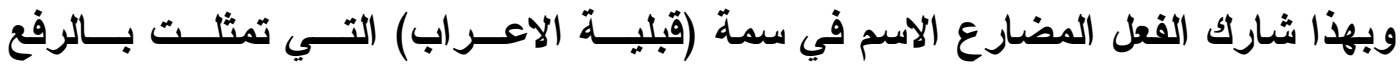

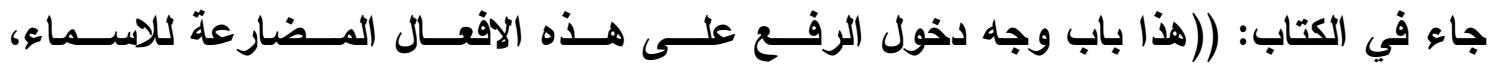

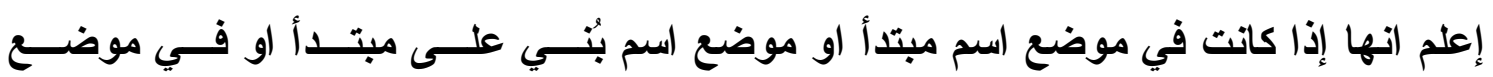

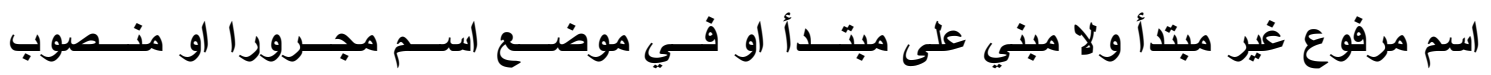

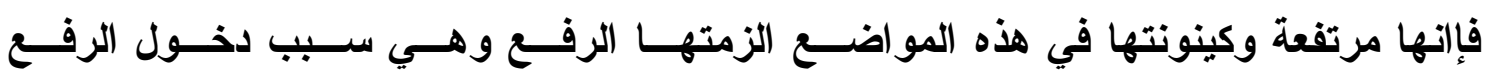
فيها)( فيان)

ونص سيبويه يشير الى ان الفعل المضارع شـــارك المبتـــأ فــي حالــة الرفـــع بغيـر

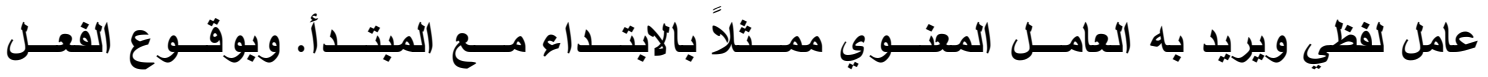

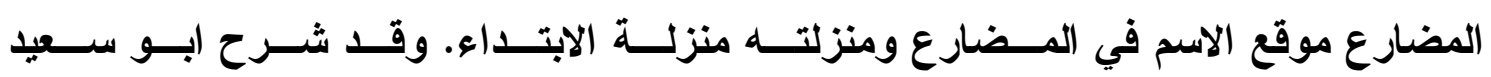

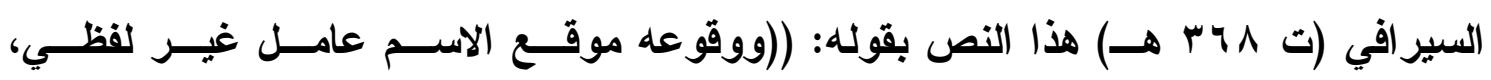

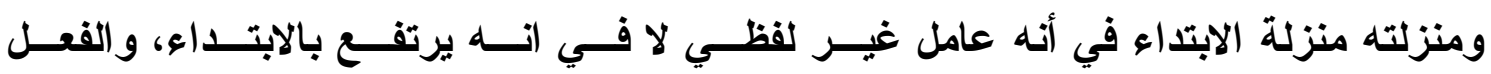

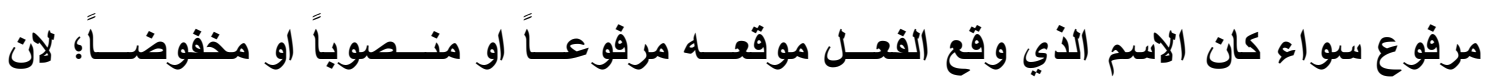

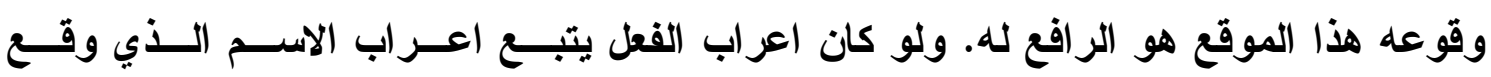

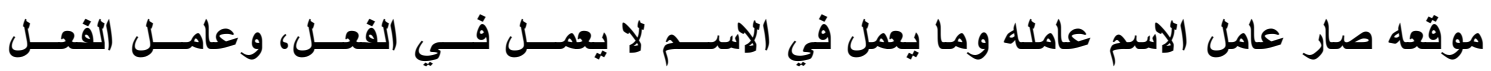

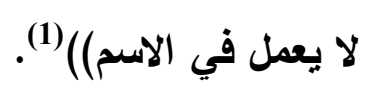

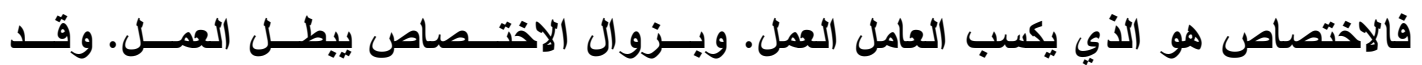

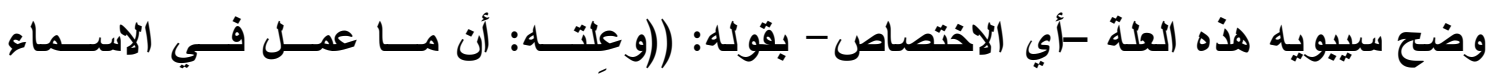

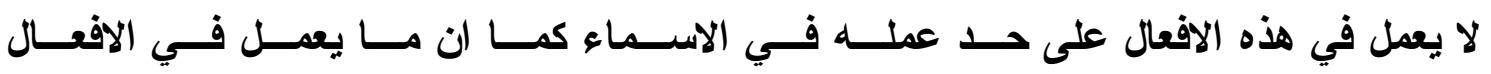

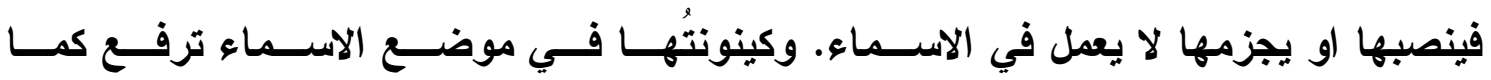

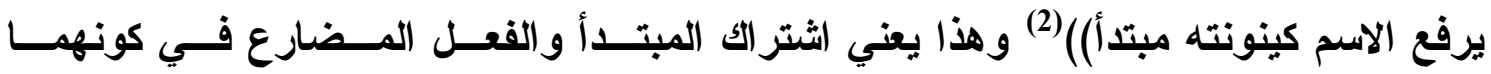

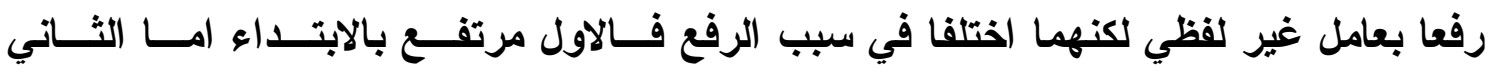

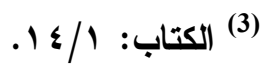

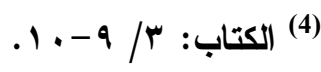

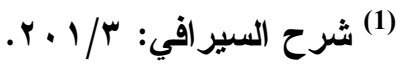

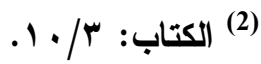




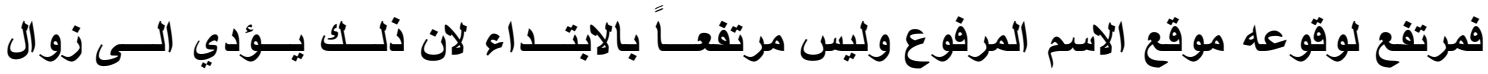

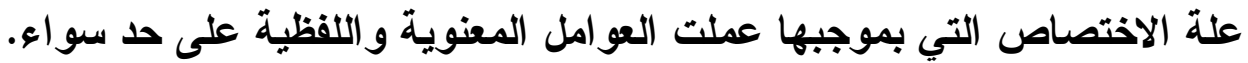

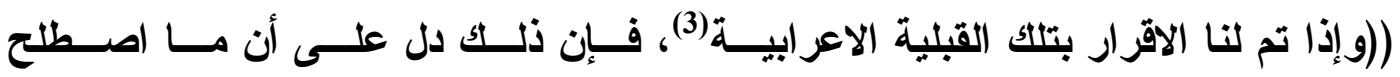

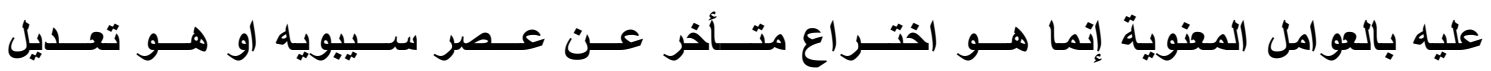

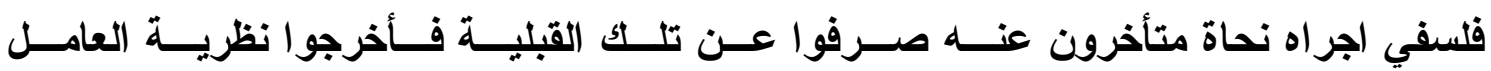

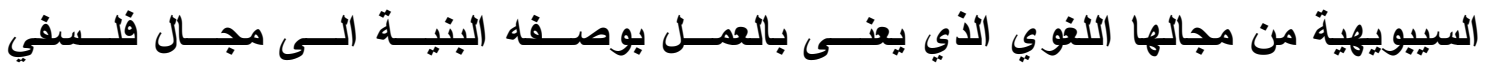

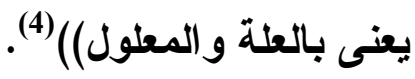

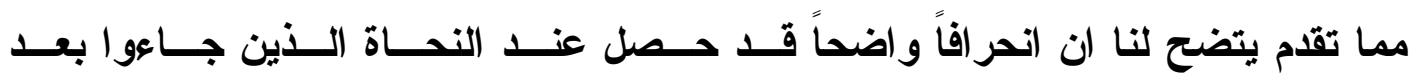

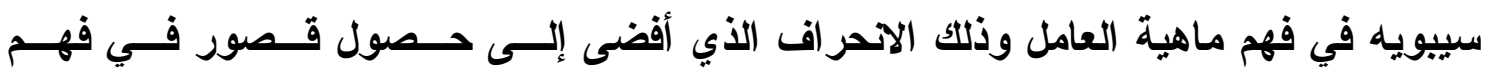

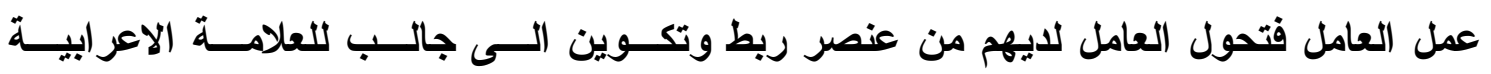

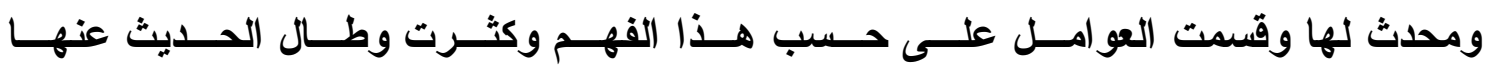

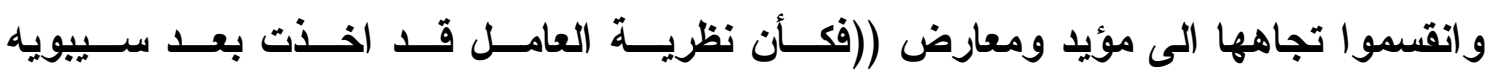

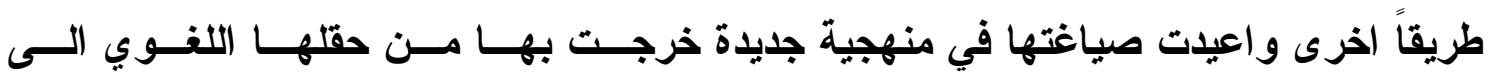

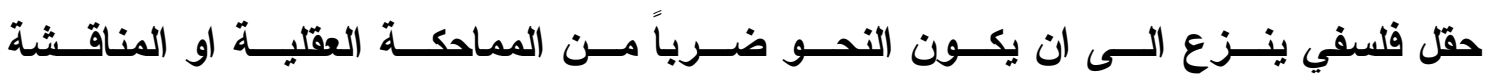

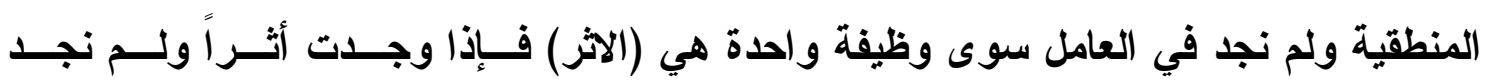
له عاملاً سابقاً عليه (حتالت لنفسها في ان تجد عاملاً معنوياً اوجد ذلك الاثر))(1).

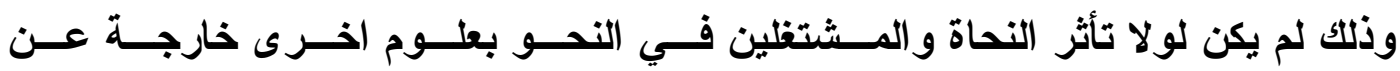

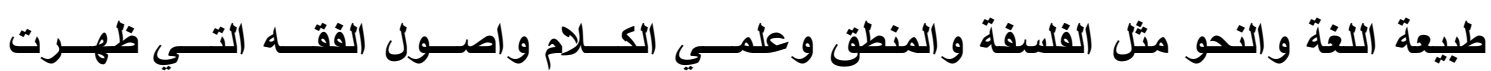

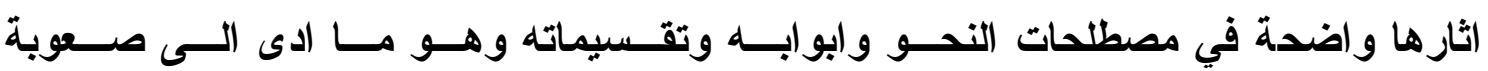
النحو ووعورته ونفور المتعلمين منه.

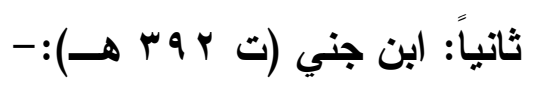

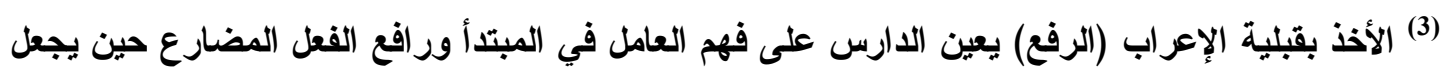

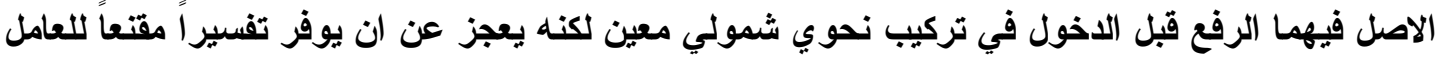

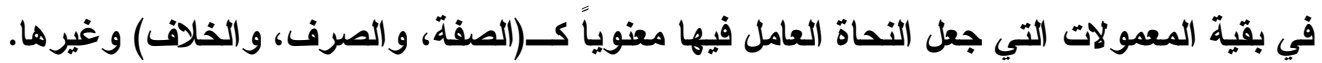

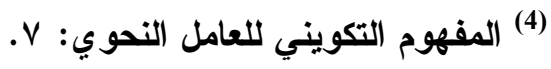

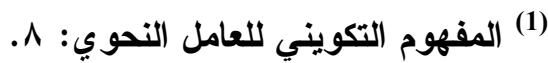




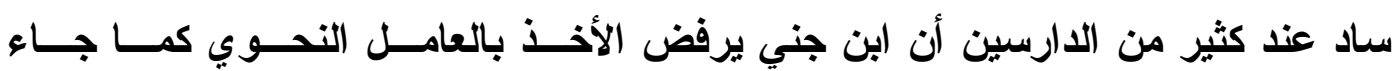

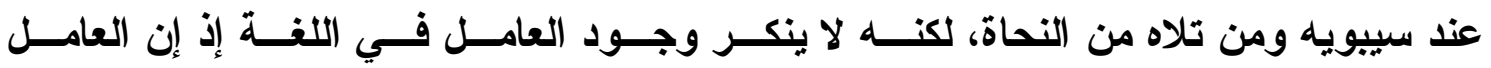

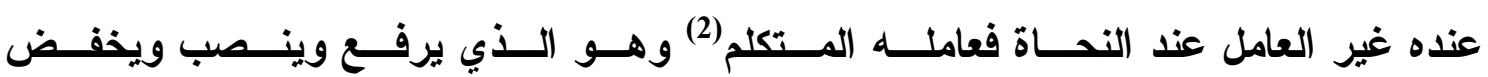

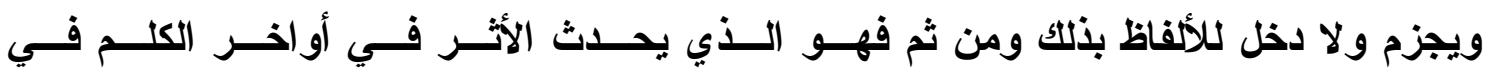
الجملة.

وقد استدلوا على ما ذهبوا إليه بنص يتيم ذكــره ابـن جنـي فـي كتابــه الخـصائص

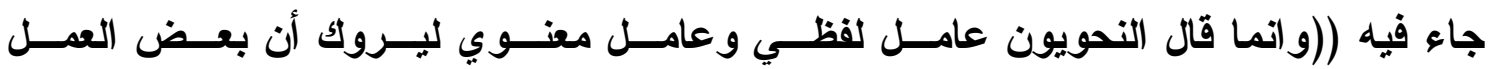

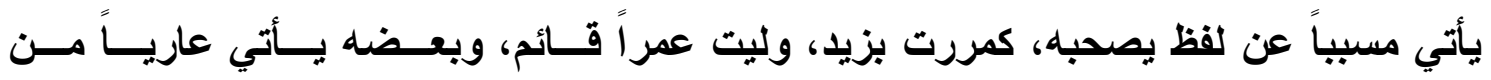

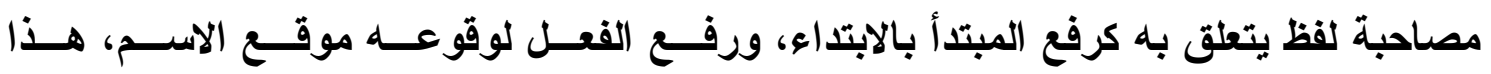

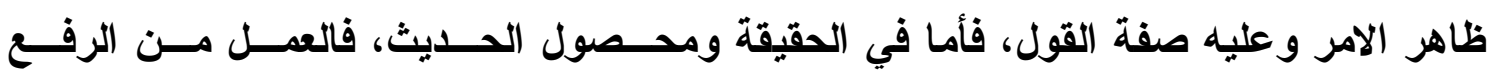

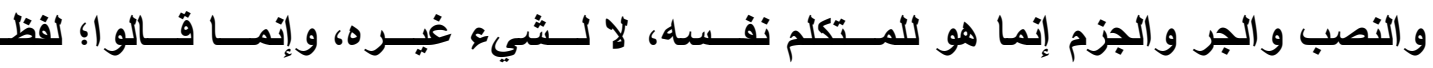

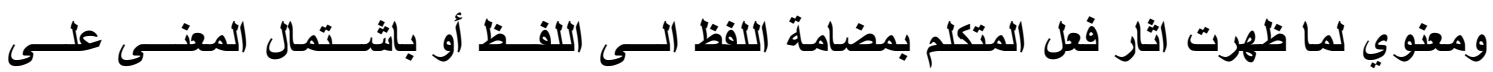
(اللفظ وهذا و اضتح)(

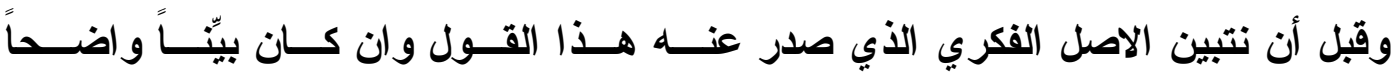

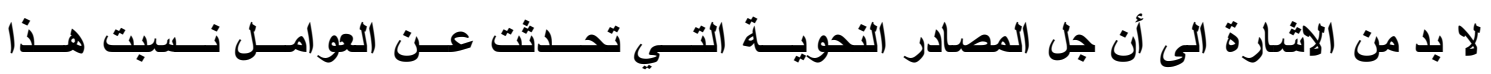

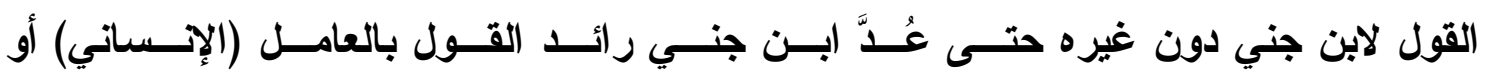
المتكنم.

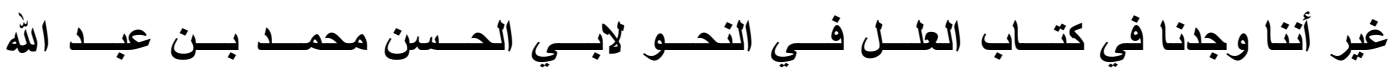

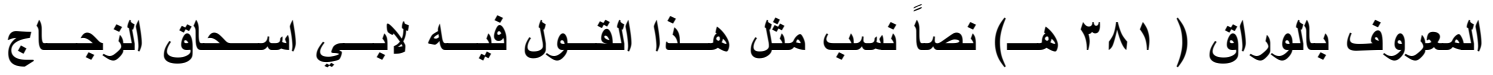

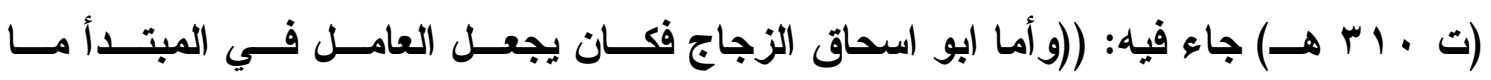
في نفس المتكلم من معنى الاخبار، قال: لان الاسم لما كان لا بـــ لــهـ مــن حـــيث يحــــ به عنه صار هذا المعنى هو الر افع للمبتدأ)(1).

(2) وقد تابعه على هذا الر أي العلامة الرضي الاستراباذي فالرضي يزى ان الموجد ((لهذه المعاني هو

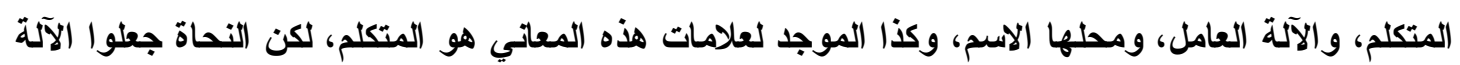

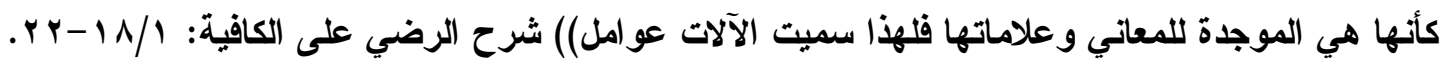

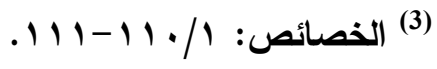

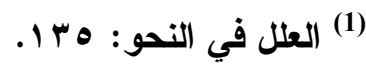




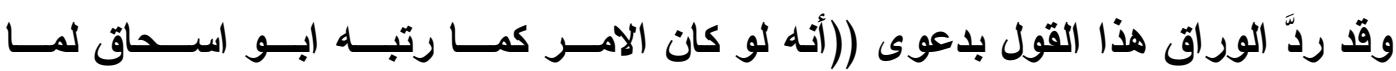

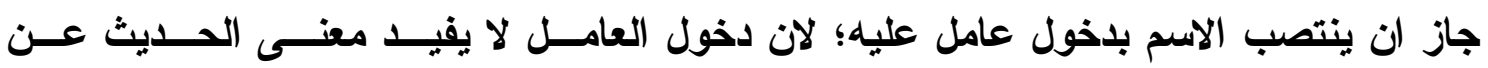

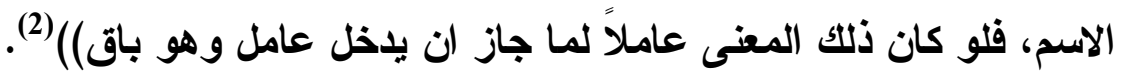

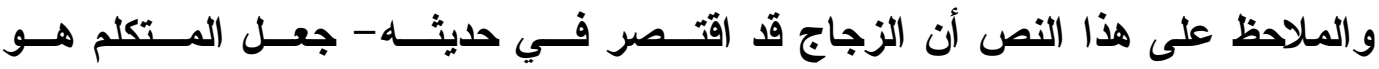

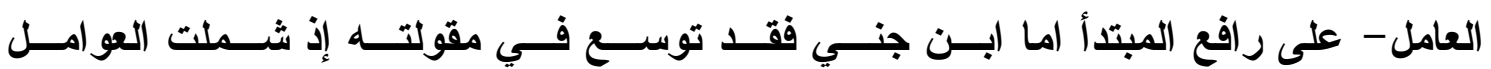

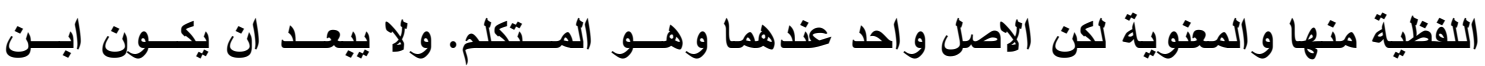
جني قد اخذ مقولة الزجاح هذه ووسعها لتشمل العوامل كلها.

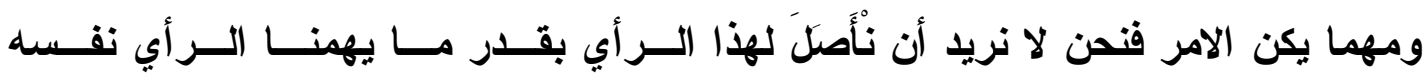
مع تحديد الاصل او الرافد الفكري لهذا الرأي.

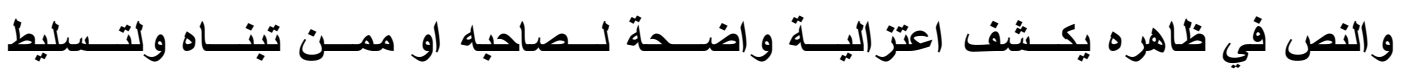

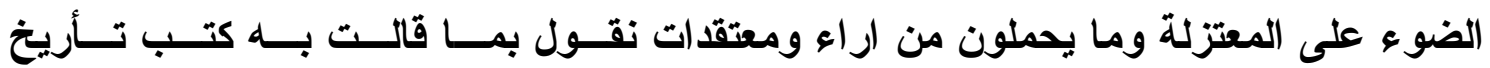

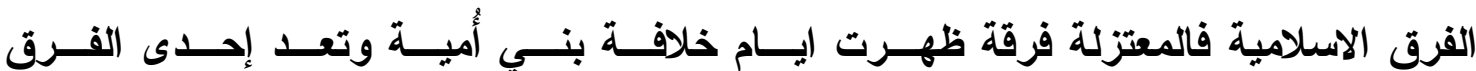
الاسملامية الخمس الكبرى (3).

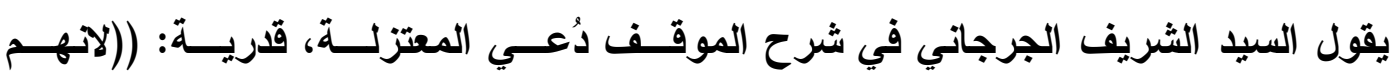

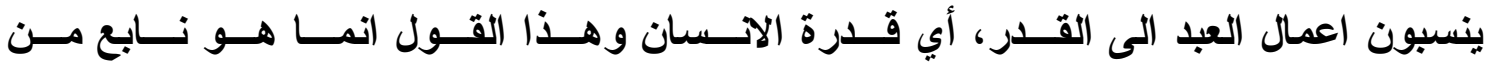

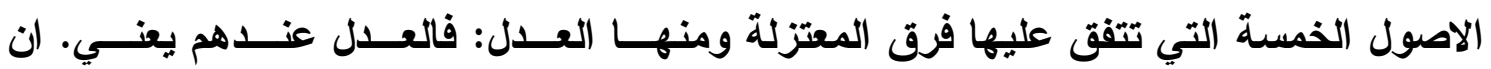

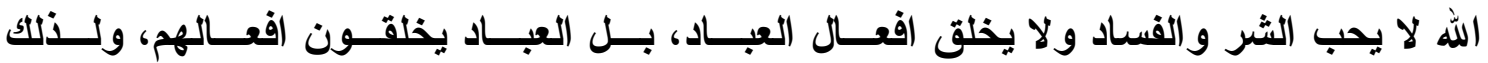

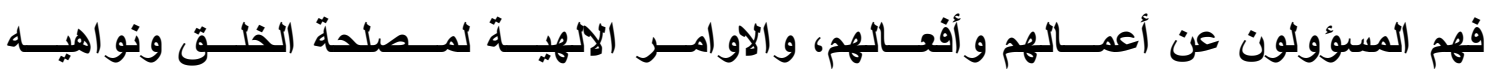

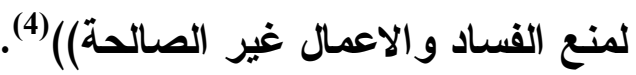

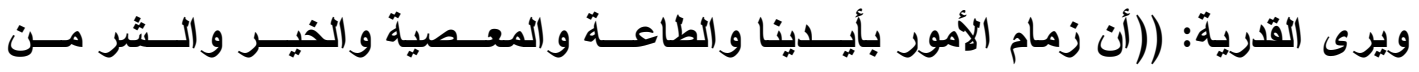

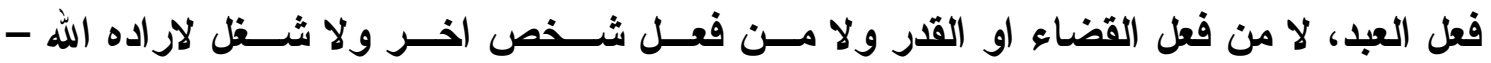

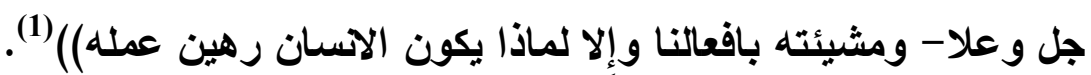

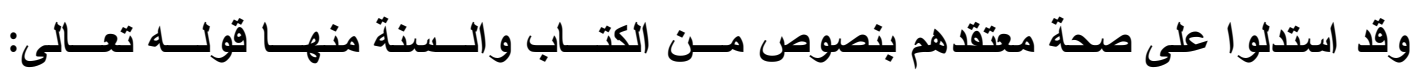

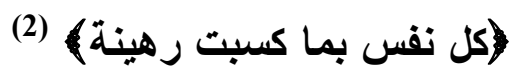

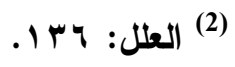

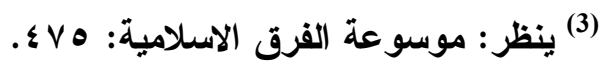
(4) (المصدر نفسه:

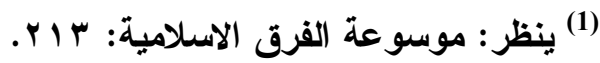


ولقب اصحاب هذه المقالة ايــضاً باصــحاب العــدل والتوحيــــ فـضلاً عــن القدريــة

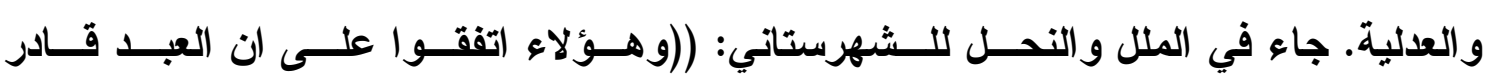

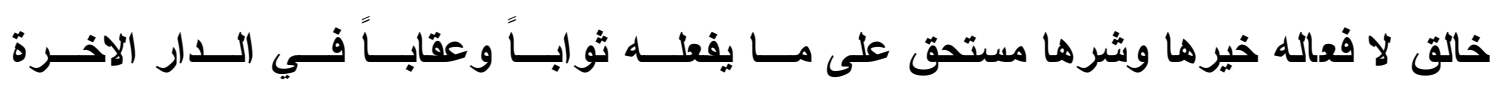

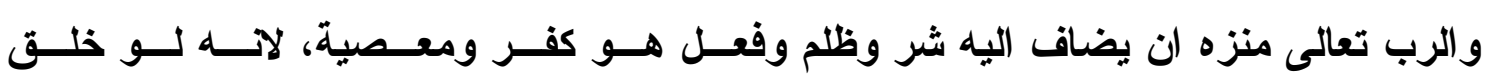

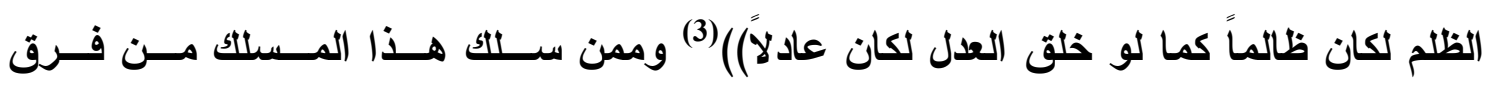

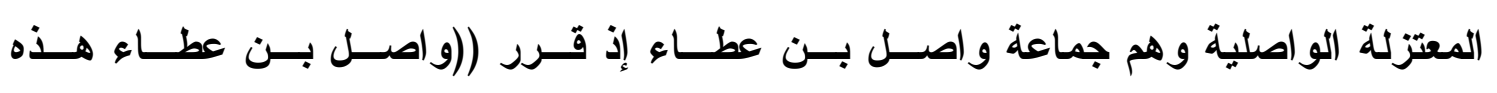

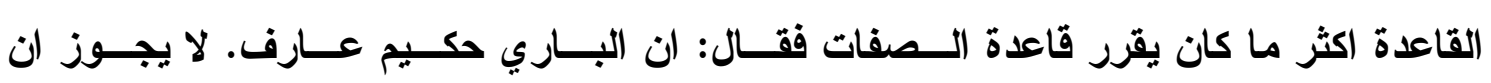
يضاف اليه شر ولا ظلم ولا يجوز ان يريد مــن العبــاد خــلاف مـــا يــأمر ويحـتم علــيهم شيئًا ثم يجازيهم عليه فالعبد هــو الفاعـل للخيـر او الــشر والايمــان والكفــر والطاعــة

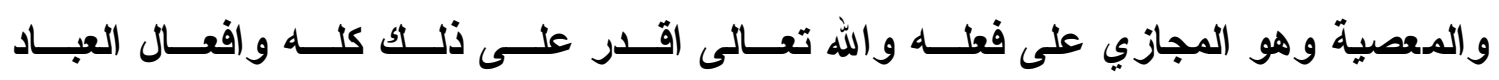

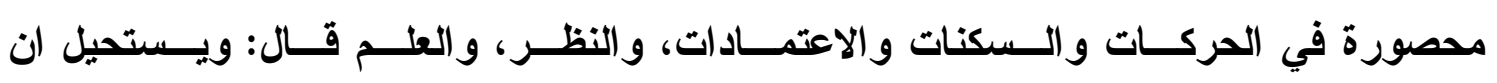
يخاطب العقل بافعل وهو لا يمكنه ان يفعل وهو يحس من نفسه الاقتدار والفعل)(4).

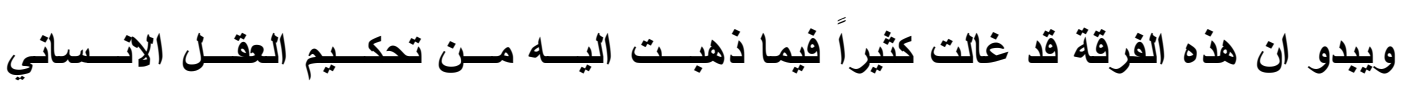

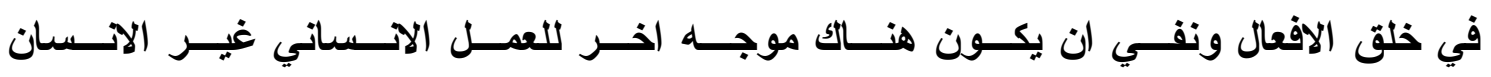

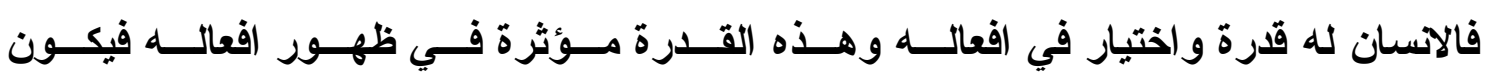

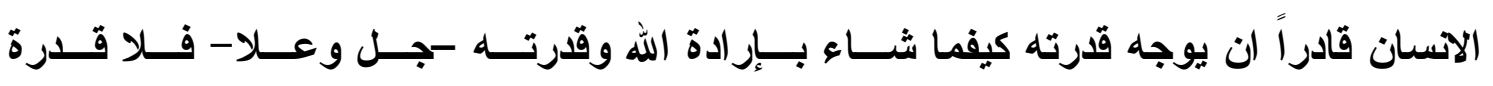

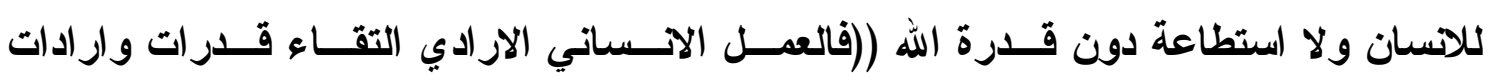
بـين الله والإسـسان دون تنــاف بـين قـدرة الله وقـــرة الآـسـان وبـين ارادة الله وارادة

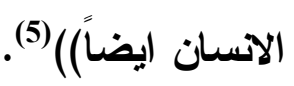
والمقصود بالعمل الار ادي ما كــان للاهـسـان قـدرة واســـطاعة وار ادة علــى القيــام

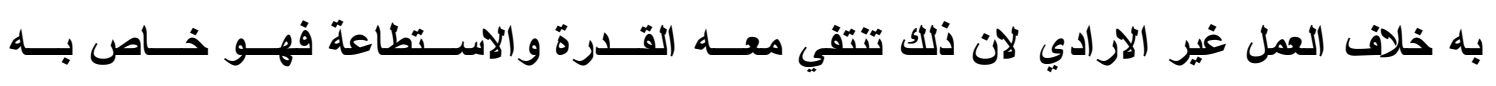

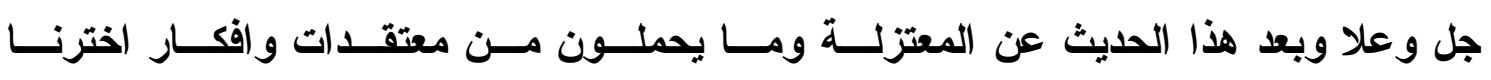

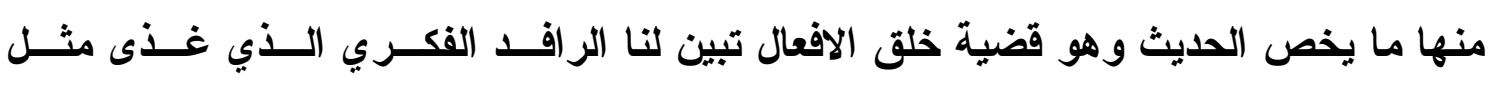

$$
\begin{aligned}
& \text { (2) المدثر: مr. } \\
& \text { (3) الملل والنحل: الملئر: }
\end{aligned}
$$

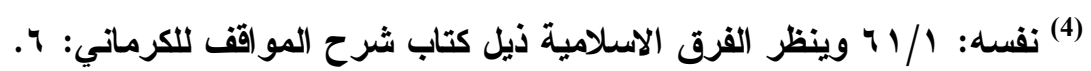

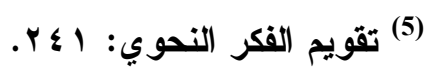




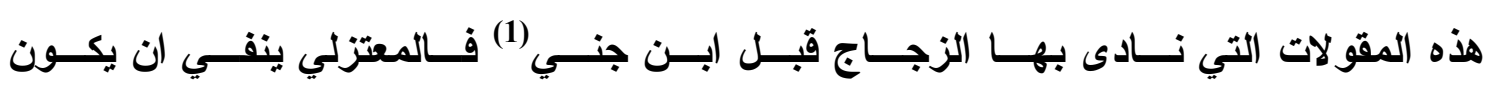

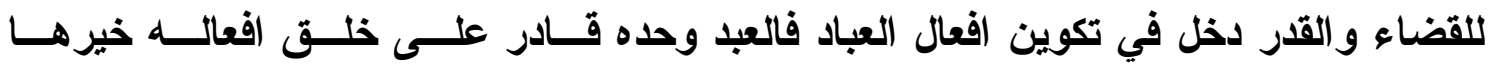
وشرها وما يترتب عليها من الايمان و المعصية و الطاعة و الكفر.

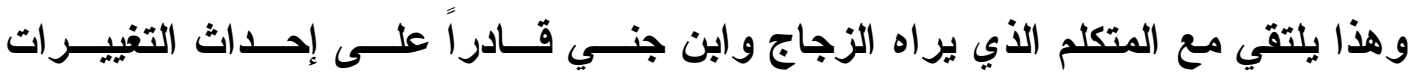

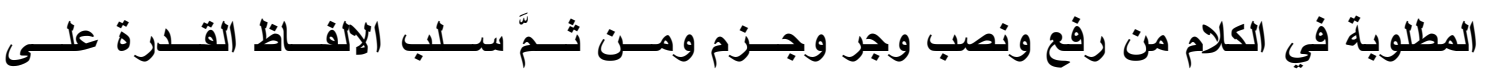

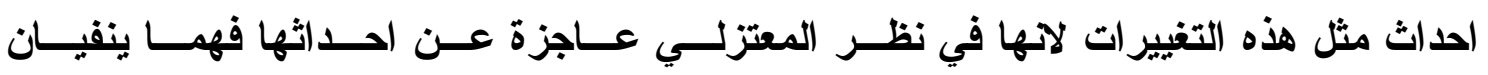

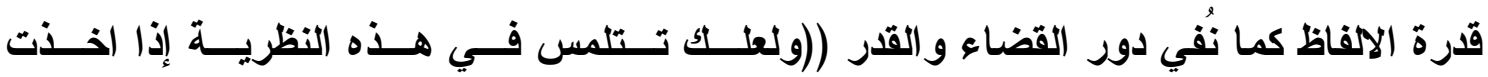

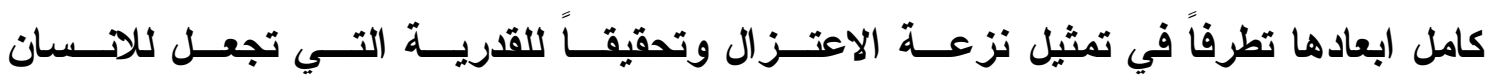

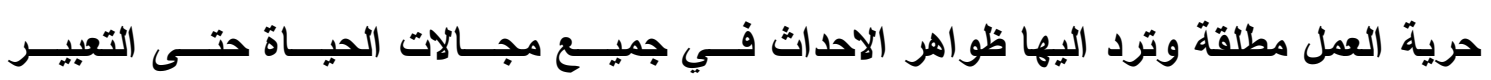

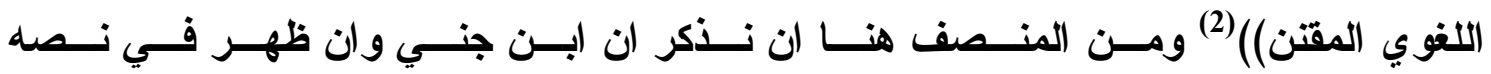

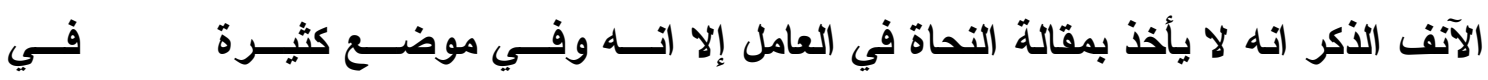

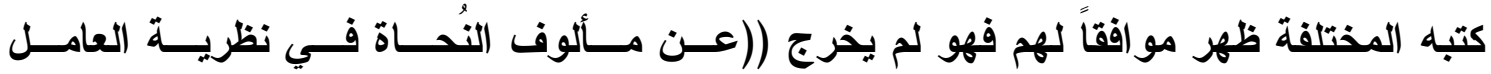

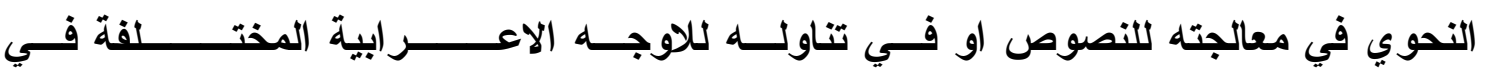

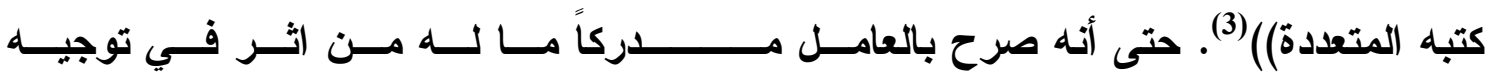

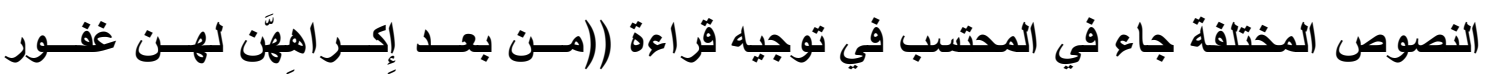
ن رحيم)(4)

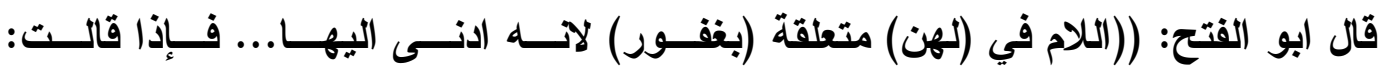

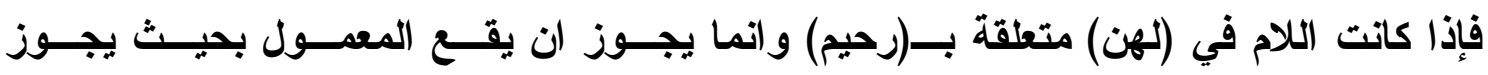

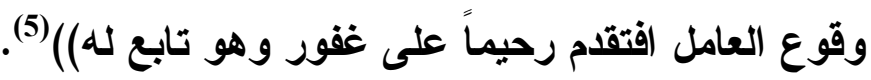

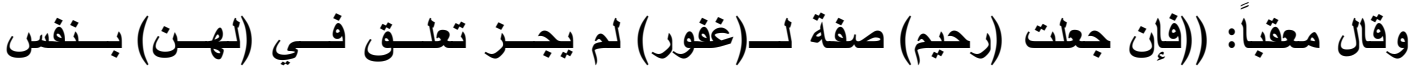

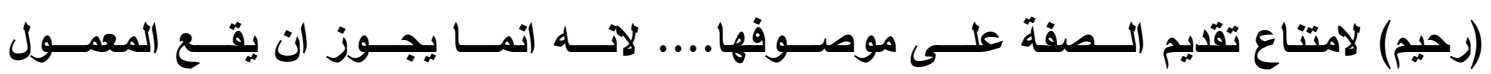

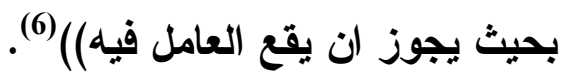

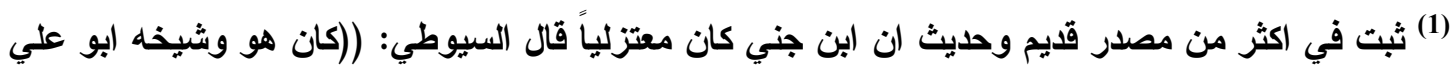

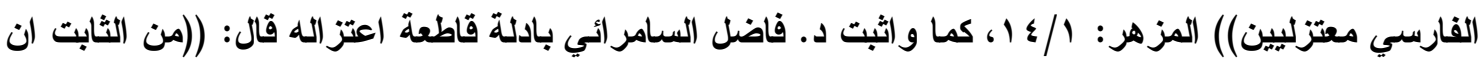

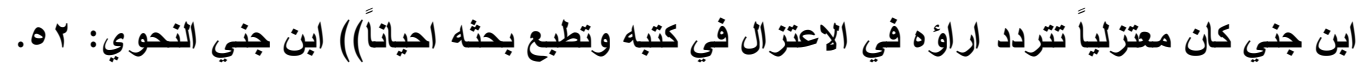

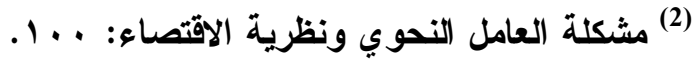

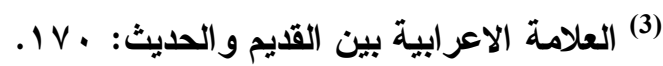

$$
\begin{aligned}
& \text { (4) }
\end{aligned}
$$

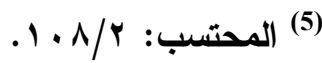




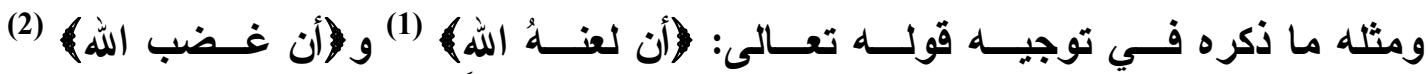

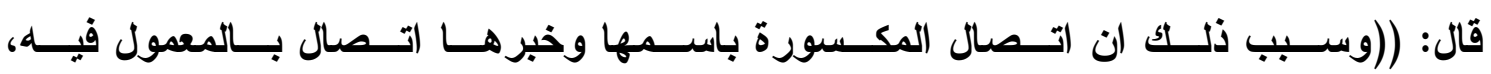

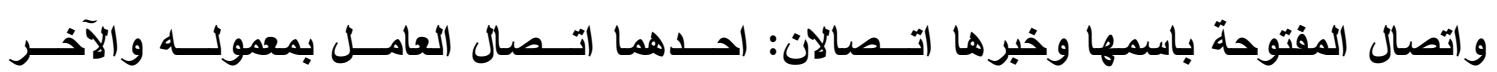

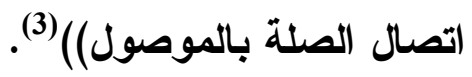

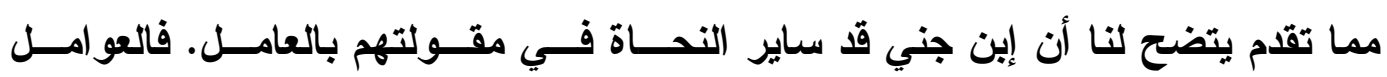
عنده لفظية ومعنوية وتعمل ظاهرة ومحذوفة، مثنقة ومخففة.

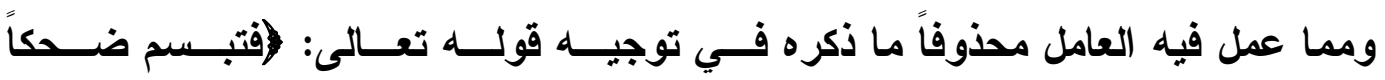

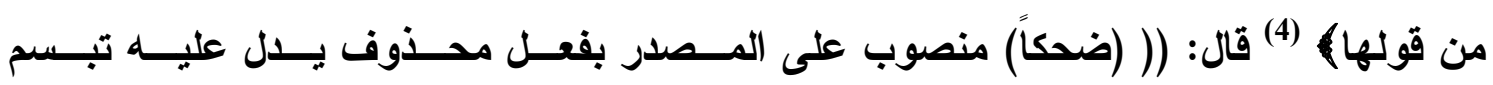

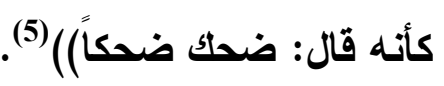

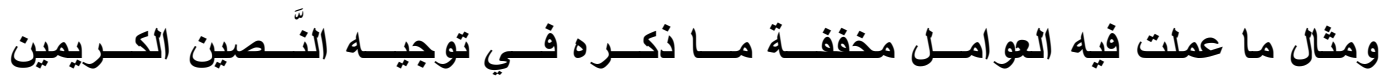

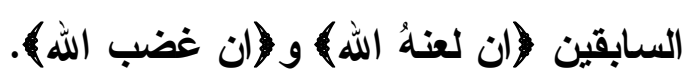

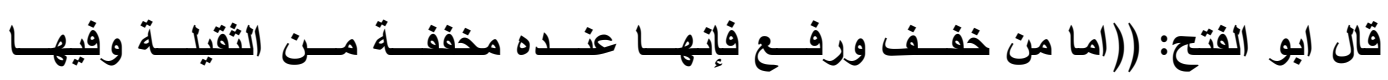

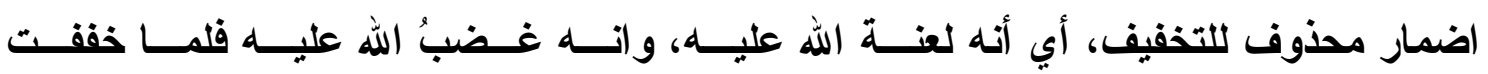

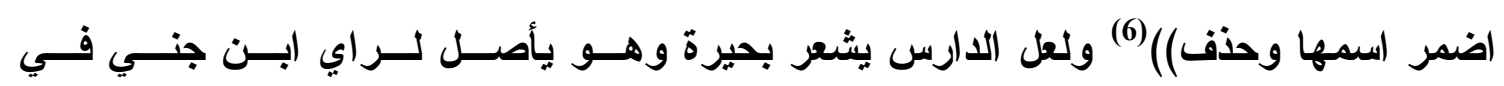

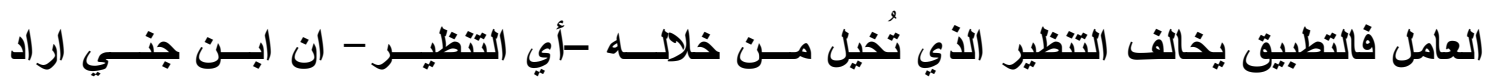

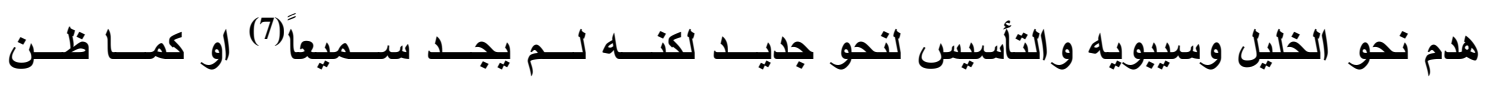

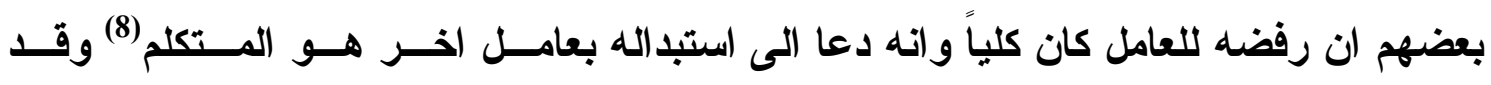

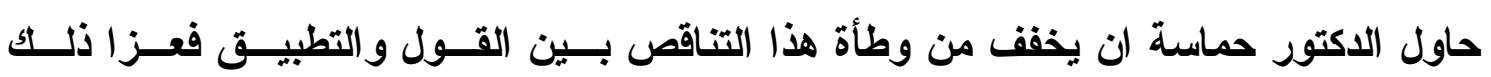

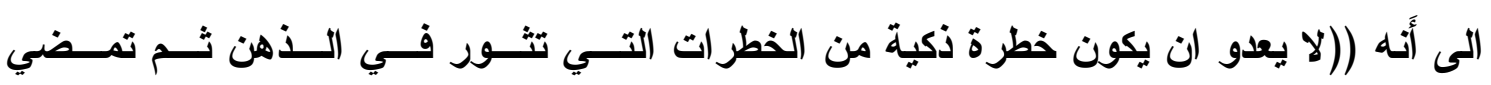

$$
\begin{aligned}
& \text { (6) } \\
& \text { (1) } \\
& \text { (النور: } 9
\end{aligned}
$$

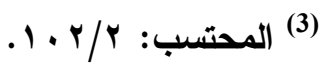

$$
\begin{aligned}
& \text { (4) (النحل: } 9 \text { (5) }
\end{aligned}
$$

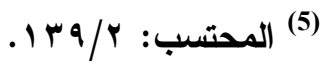

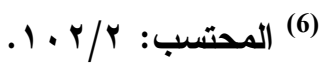

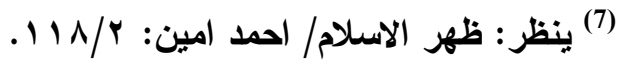

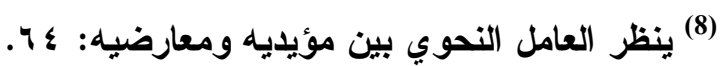




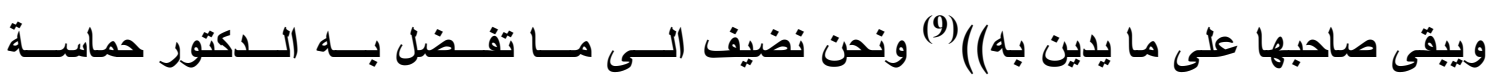

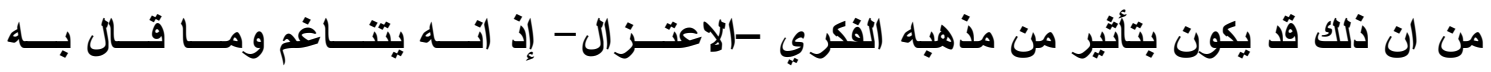

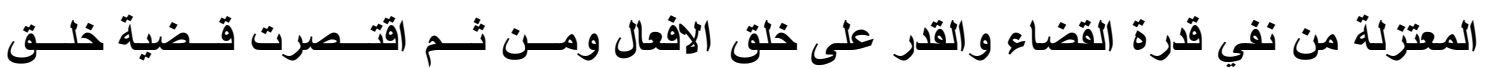

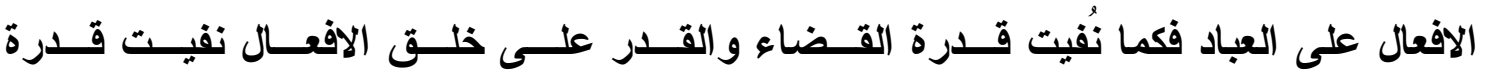

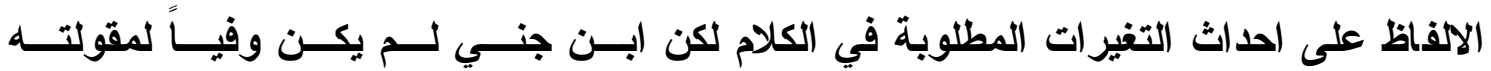

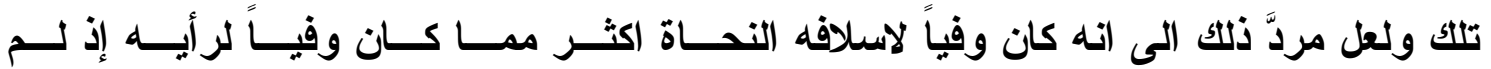
يشأ الخروج عن مألوف قرروه دئ ثالثاً: (بن مضاء القرطبي (ت ب 9 ه هـ):

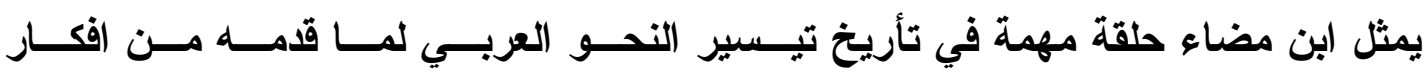

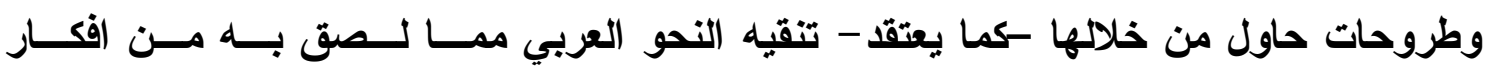

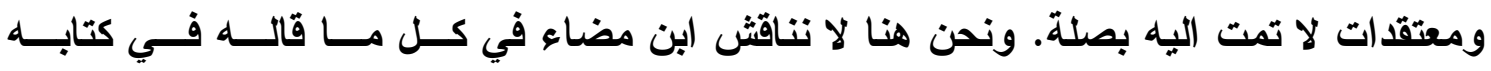

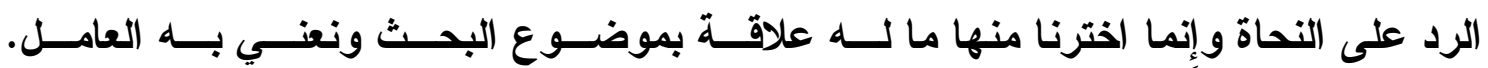

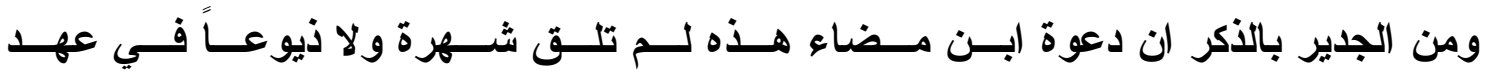

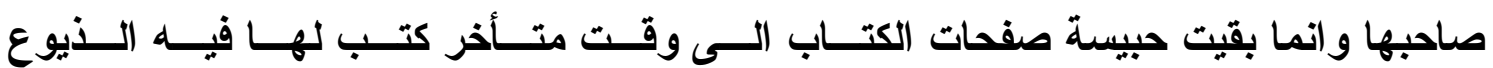

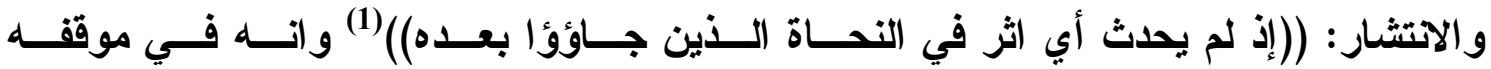

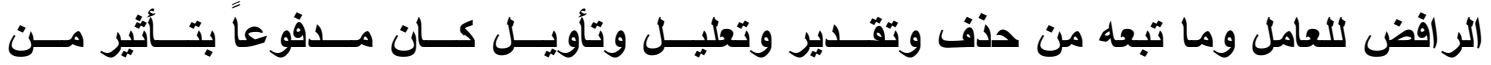

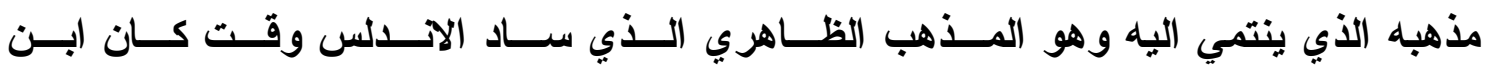
مضاء قاضيًاً فيها.

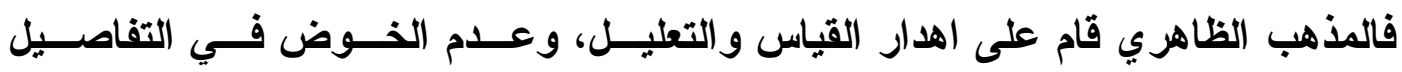

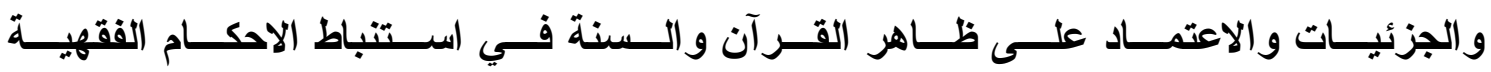

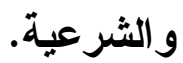




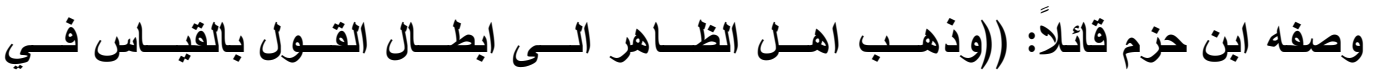

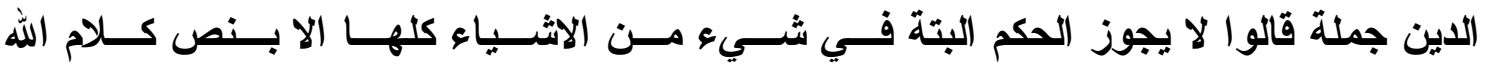

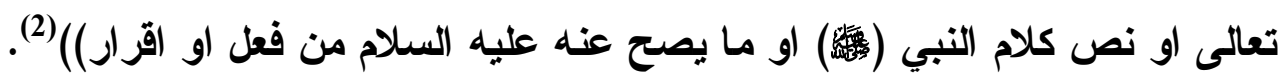

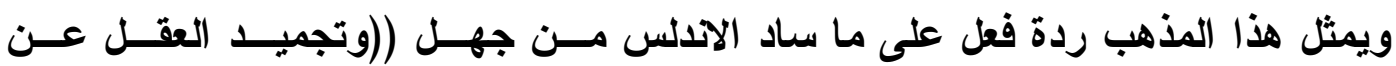

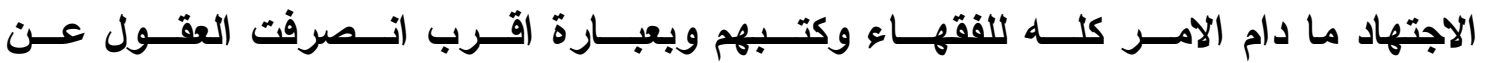

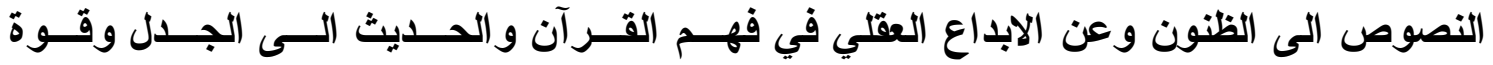

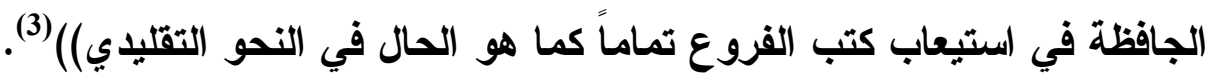

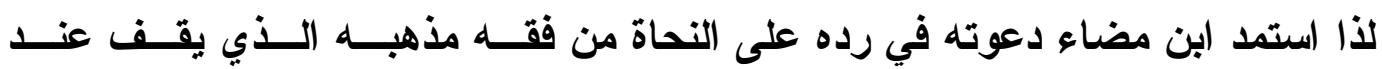

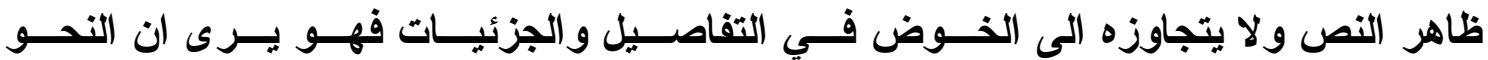

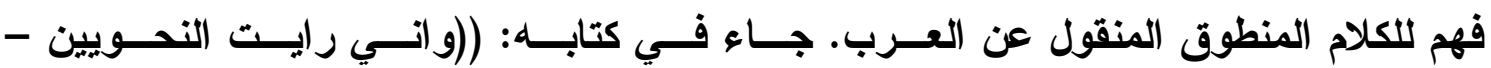
رحمة الله عليهم- قـ وضعوا صناعة النحو لحفــ كـلام العـرب مـن اللحـن، وصـياتنه

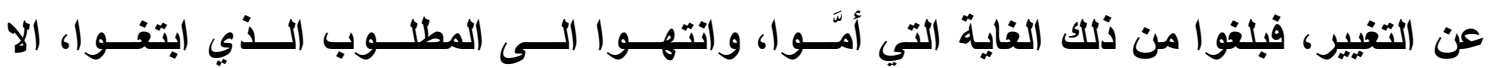

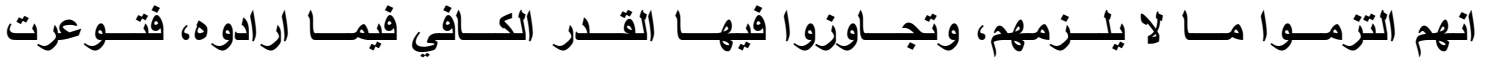

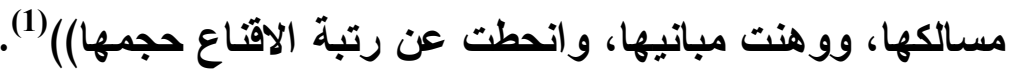

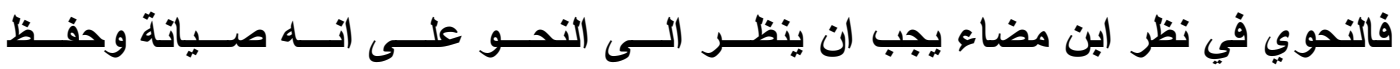

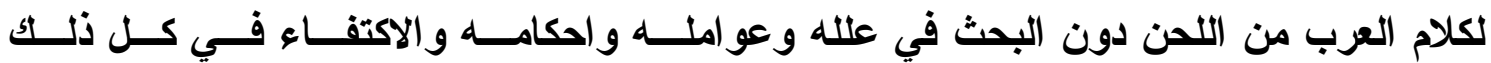

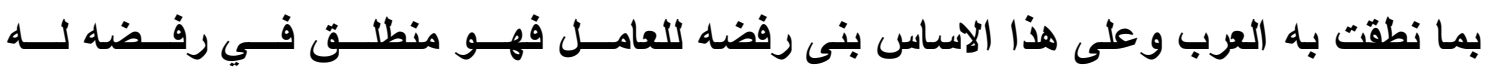

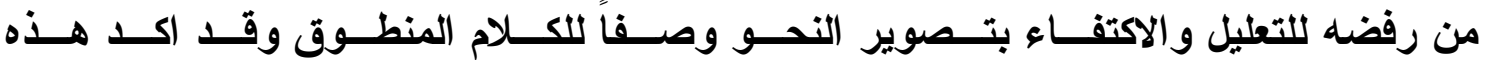

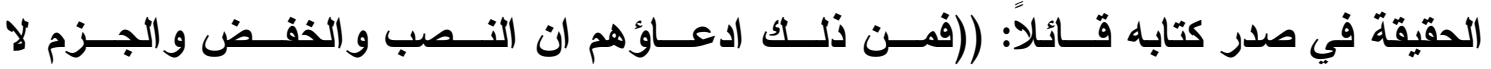

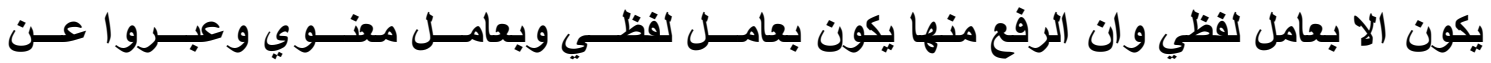

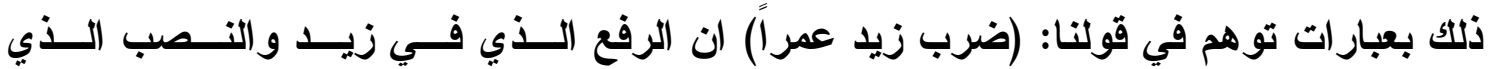

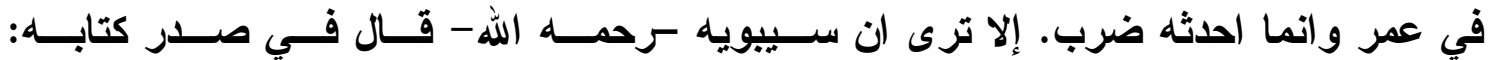

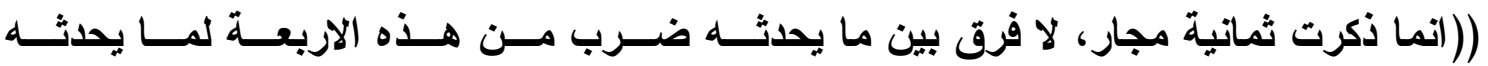

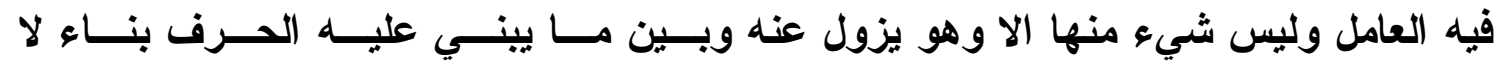

$$
\begin{aligned}
& \text { (2) الإحكام في اصول الاحكام: / / / هـ. }
\end{aligned}
$$

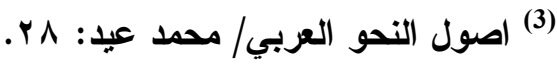

$$
\begin{aligned}
& \text { (1) الرد على النحاة: VY Y V. }
\end{aligned}
$$




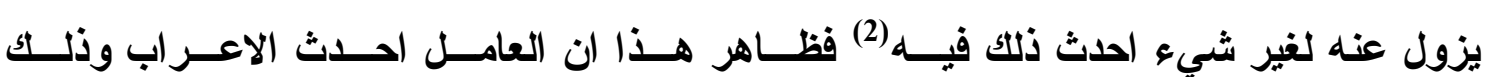

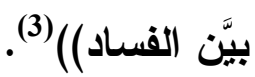

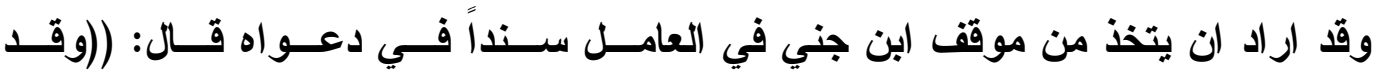

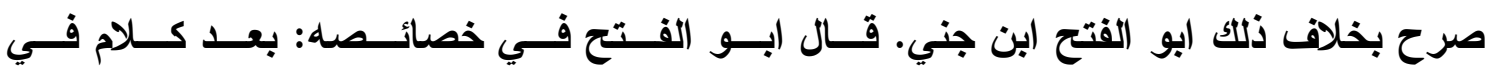

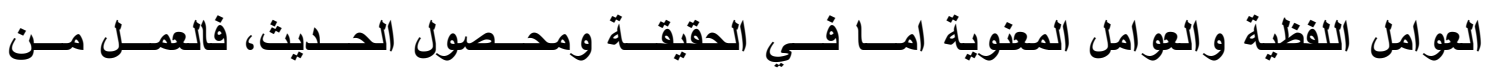

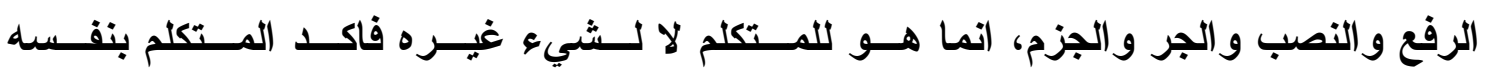

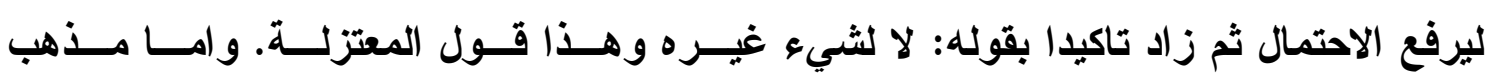

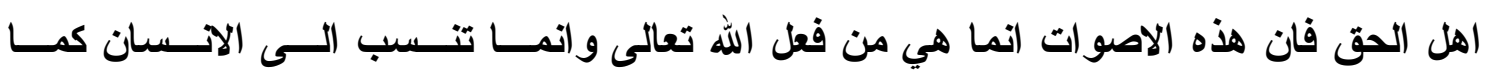

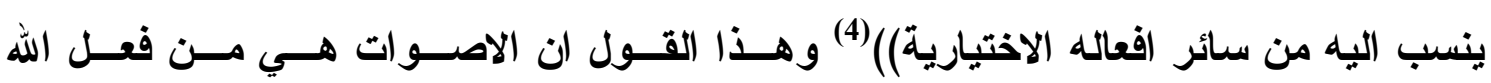
تعالى يُظهر (بن مضاء جبرياً خالصاً (5).

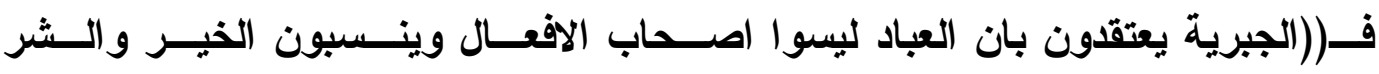

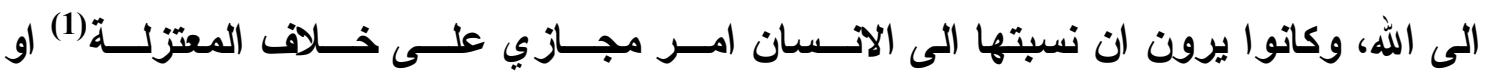

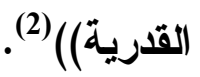

\section{فالجبر: ((هو نفي الفعل حقيقة عن العبد واضافته الى الرب))(3)}

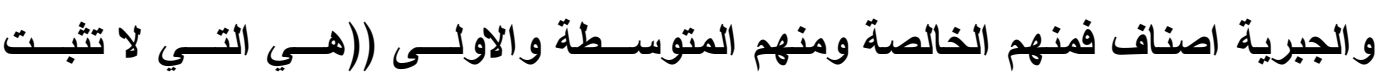

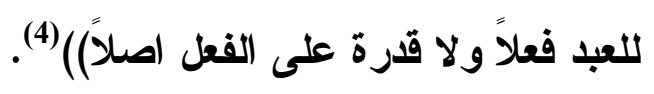

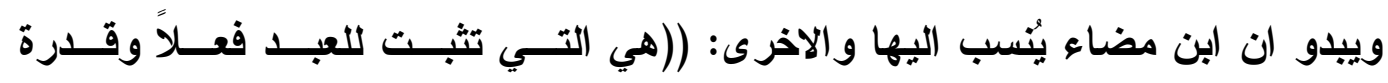

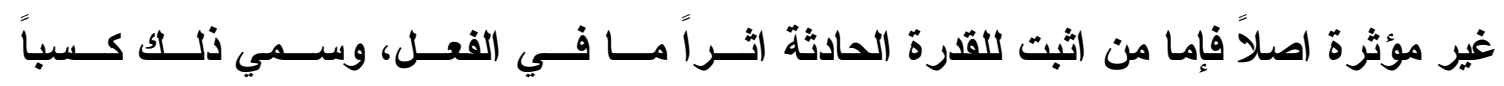

$$
\begin{aligned}
& \text { (2) (الكتاب: 1 1 1) } \\
& \text { (3) الرد على النحاة: VV. } \\
& \text {. نفسه: (4) }
\end{aligned}
$$

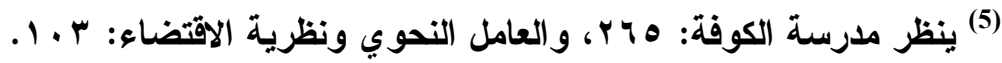

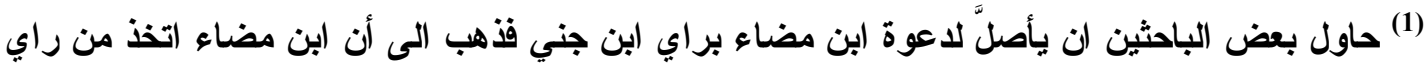

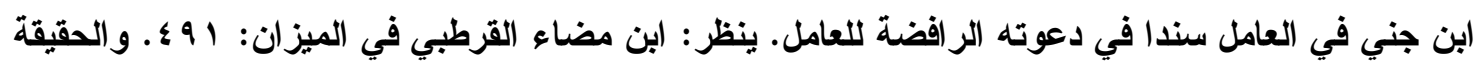

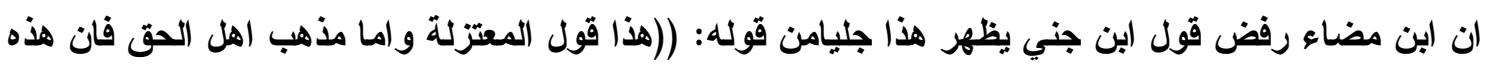

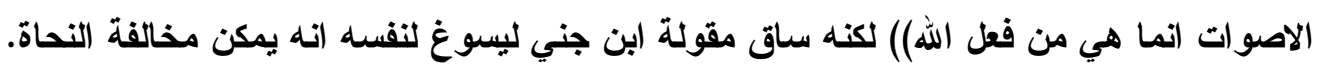

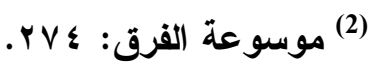

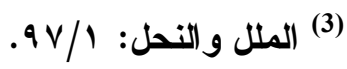

$$
\begin{aligned}
& \text { (4) نفسه: }
\end{aligned}
$$


فليس بجبري)(5) ومؤسس هذه (الفرقة الجهم بن صــفوان وهــو مــن الجبريــة الخالـصة

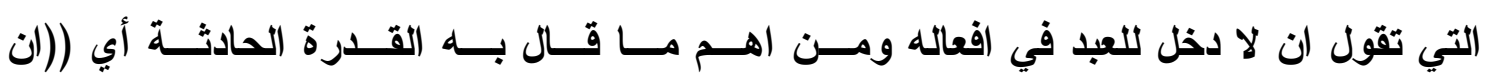

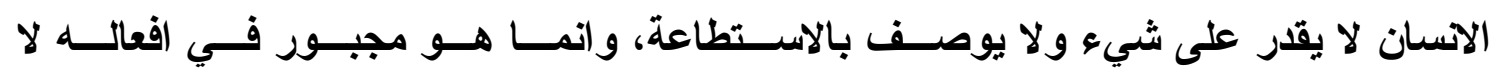

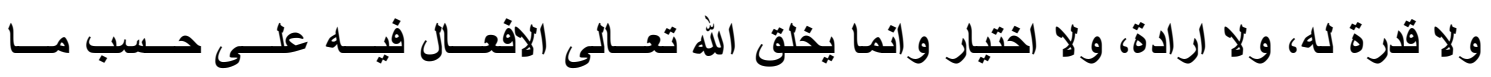

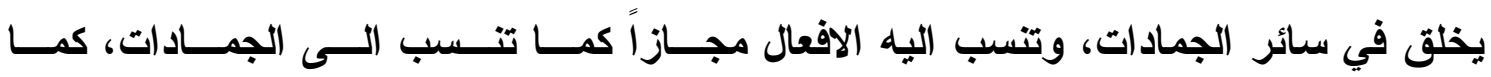

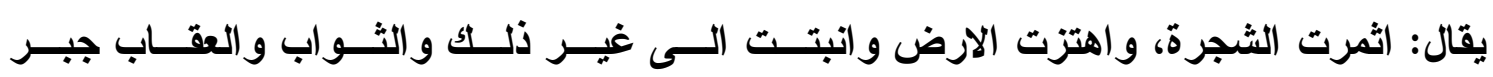
كما ان الافعال كلها جبر. قال: و إذا ثبت الجبر فالتكليف ايضاً كان جبراً)(6).

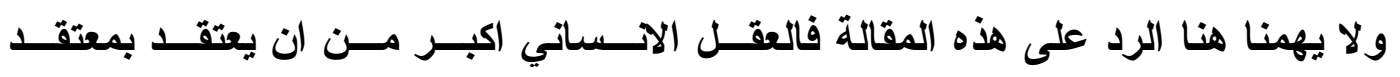

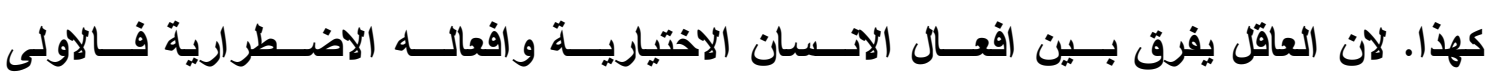

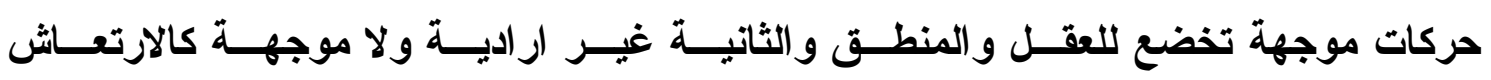
الداخلي وق وقفت اهداف سياسـية وراء ظهـور مثــل هــذه المقــولات لا يتـسع المجــال

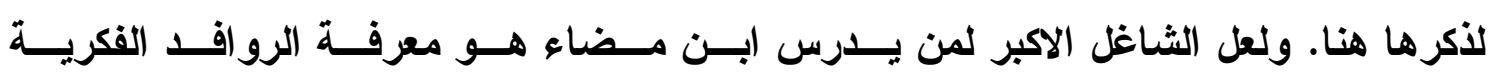

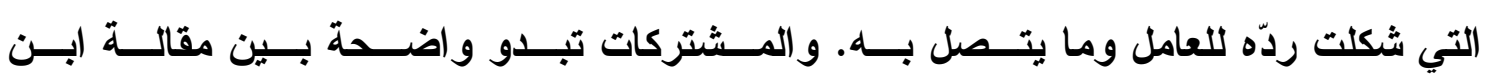

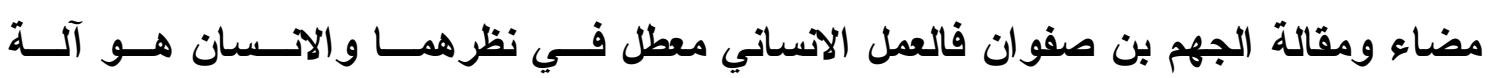

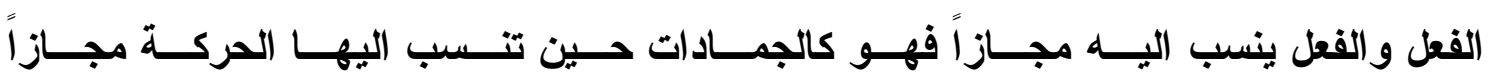
فالشجرة لا تتحرك بار ادة وكـــا الــشمس والــسماء والارض واتمـــا تحــرك بقــوة خفيــة

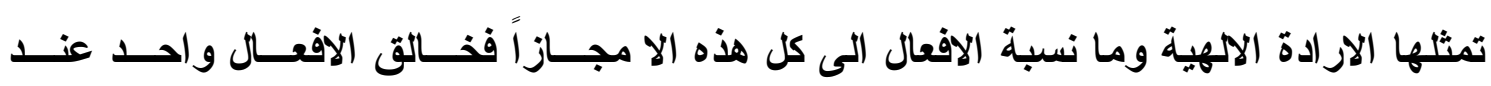

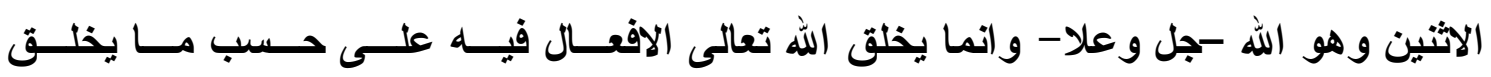
وعند ابن مضاء إن هذه الاصوات انمــا هــي مــن فعـل الله تعــالى إذن القــــرة او الارادة على تكون الفعل منتفية ولا مجال لها عند من يأخذ بمقالات الجبر.

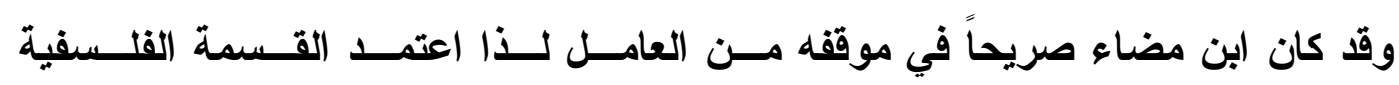

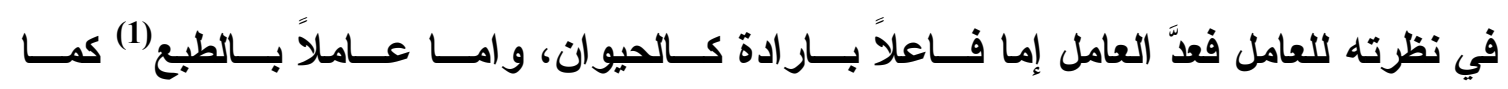

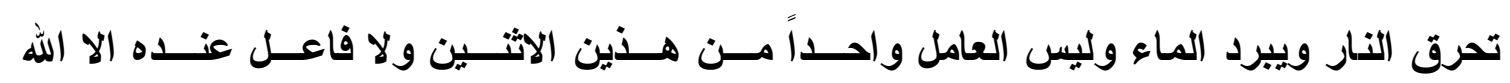

$$
\begin{aligned}
& \text { (5) الملل و النحل: } \\
& \text { (6) نفسه: (1) }
\end{aligned}
$$

(1) ويبدو انه كان متأثراً بقسمته هذه بنحاة سابقين كالانباري الأي سلب صفة التأثير عنها حين قال: (لان

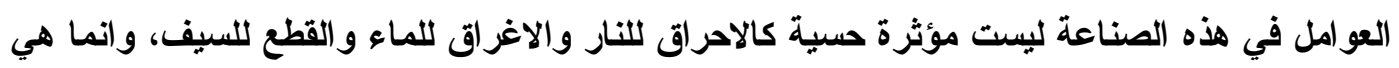

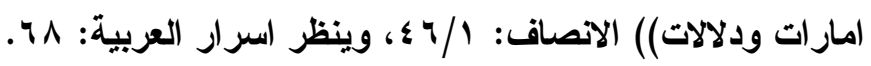


تعالى، قال: (وولا فاعل الا الله عند اهل الحـق، وفعـل الانسـسان وســائر الحيوانــات فعـل

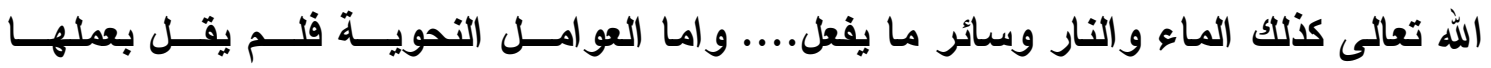

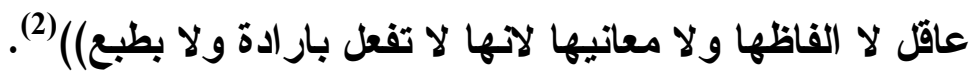

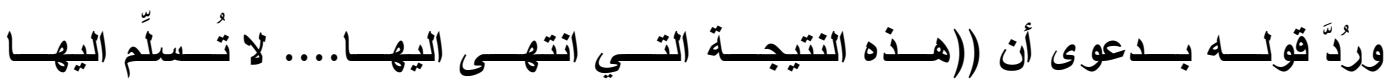

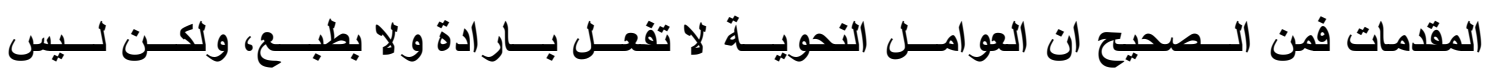

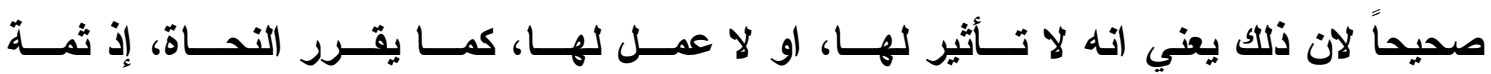

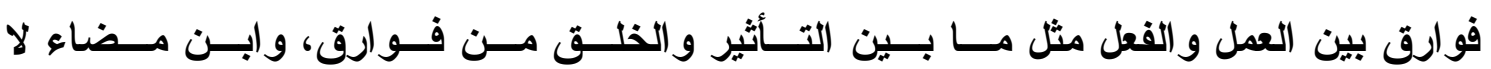

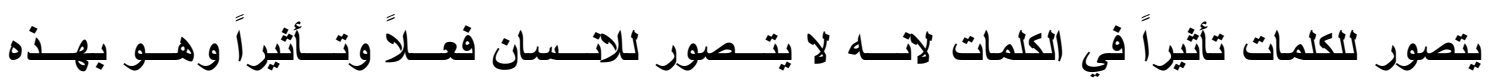

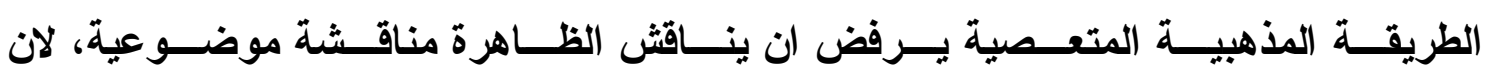

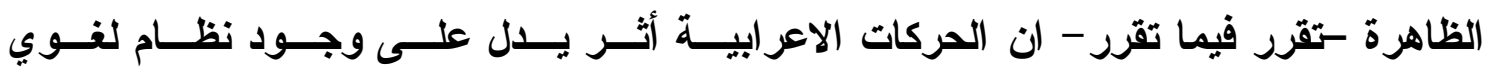

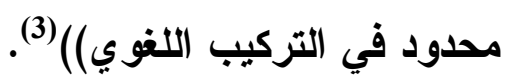

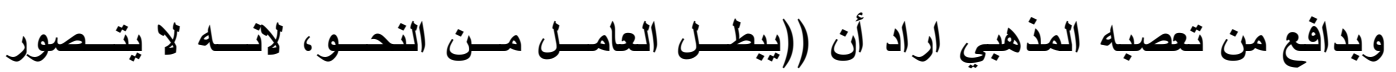

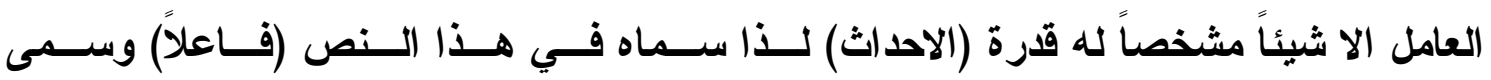

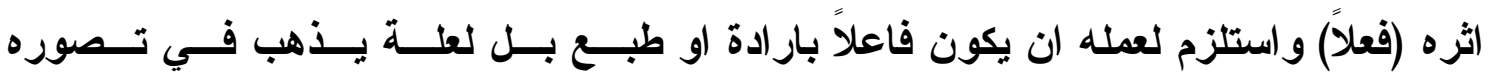

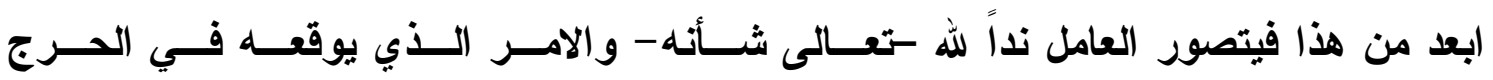

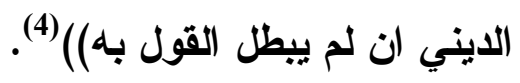

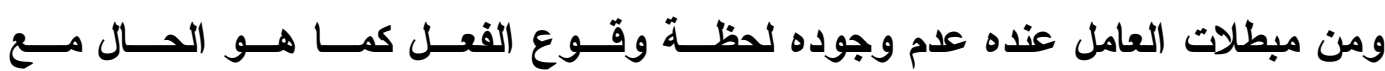

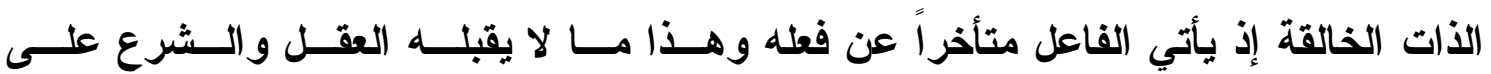

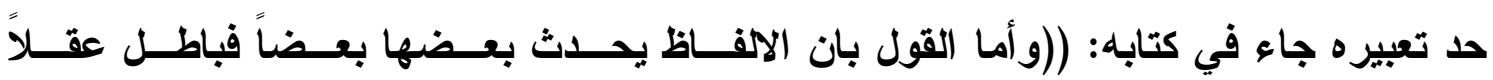

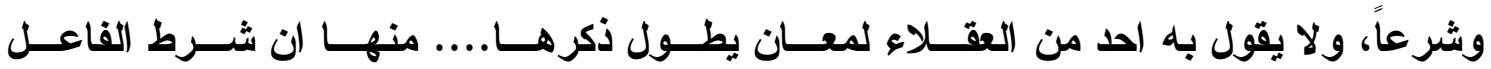

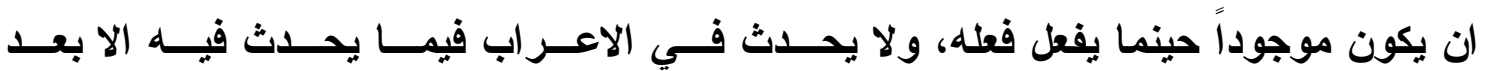

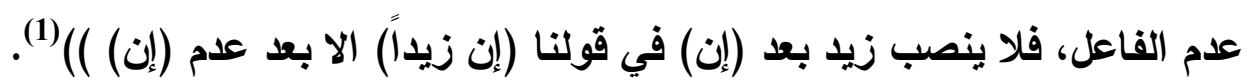

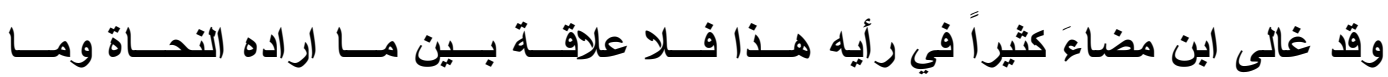

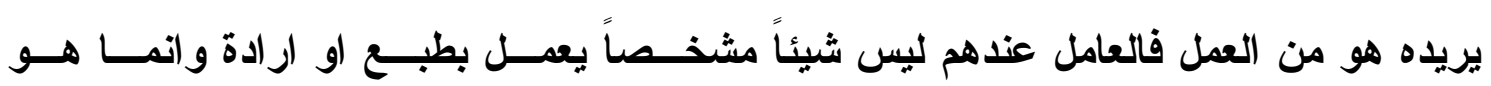

$$
\begin{aligned}
& \text { (الرد على النحاة: (2) } \\
& \text { (3) الظواهر اللغوية في التراث: } 99 .
\end{aligned}
$$

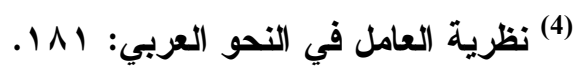

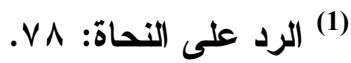


مؤثر وجالب للعلامة الاعر ابية ولا علاقة له بــالخلق او الايجـاد فجــال الخــق والايجــاد غير النحو .

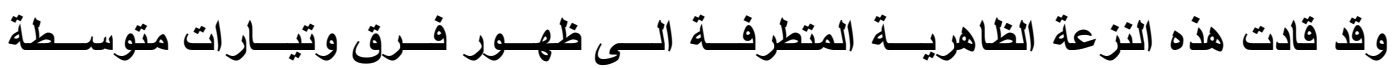

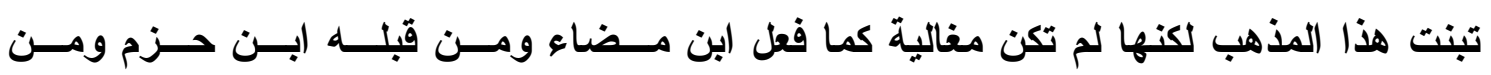

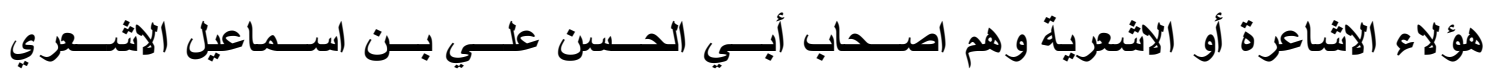

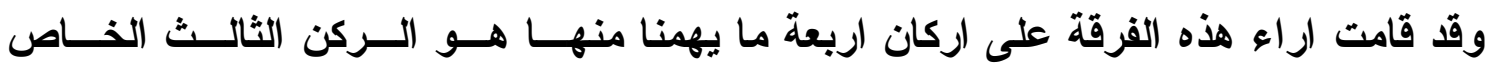

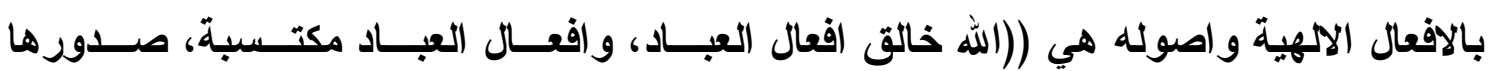
بار ادة الله، خلق الله و ابداعه من الاحسان، جواز تكليف ما لا يطاق على الله)(2(2).

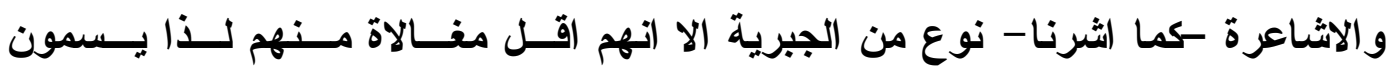

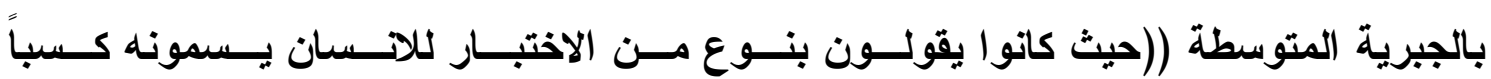

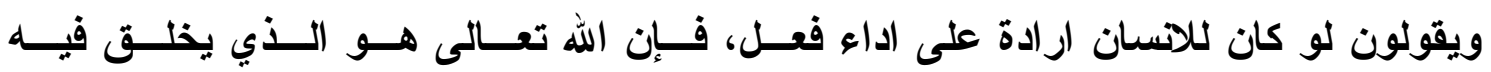

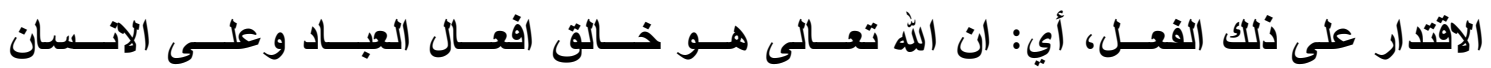

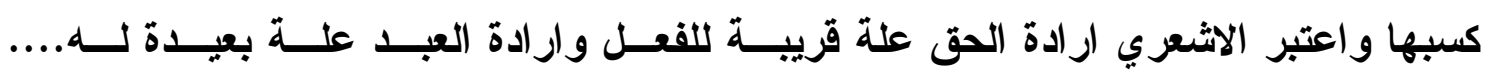

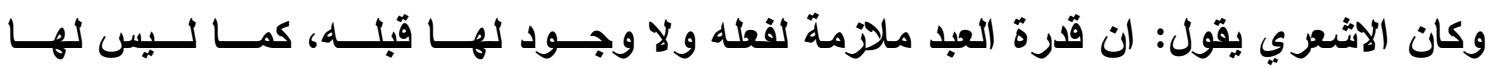

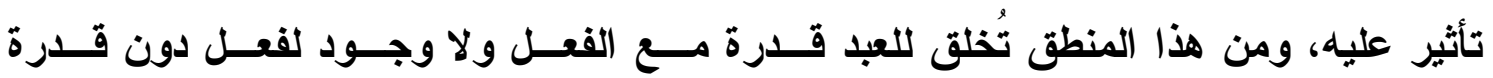

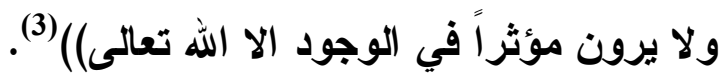

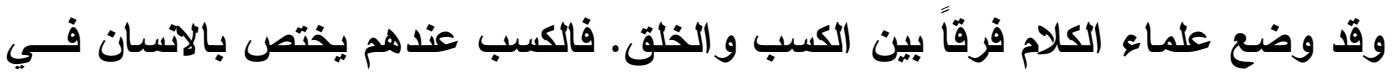

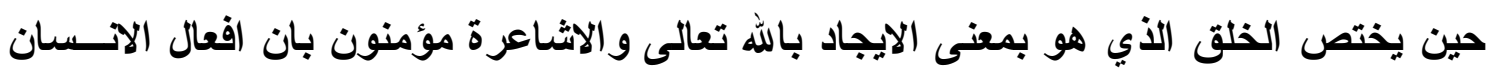
تتحقق بقرة الله وليس للانسان تأثير في خلقها و ايجادها (4).

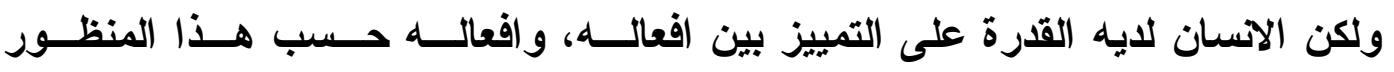

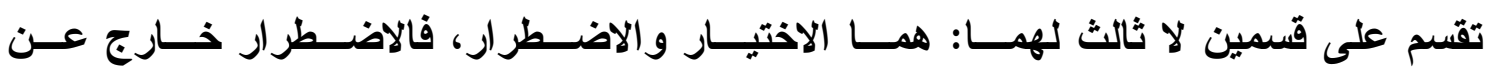

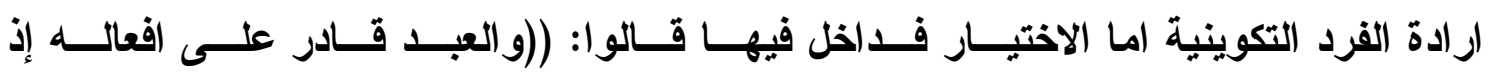

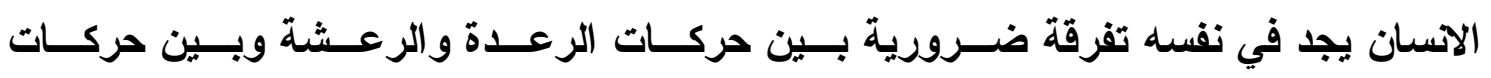

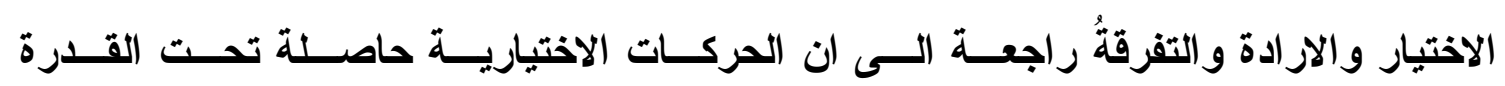

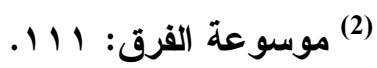

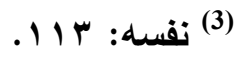

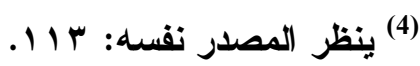


متوقفة على اختيار القادر فعـن هــذا قــال: المكتـسب هـــو المقــدور بالقــدرة الحاصــلة، و الحاصل تحت القدرة (لحادثة)(1).

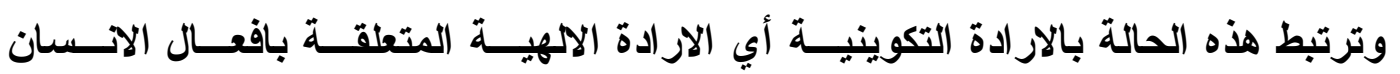

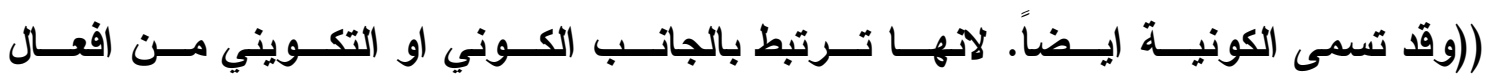

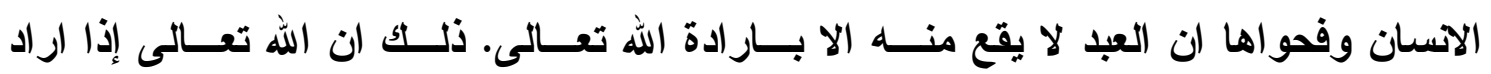

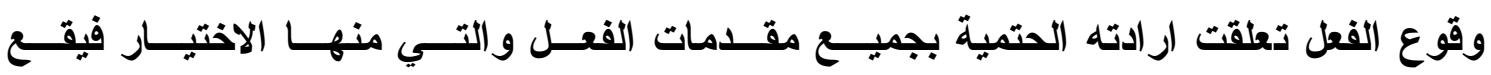

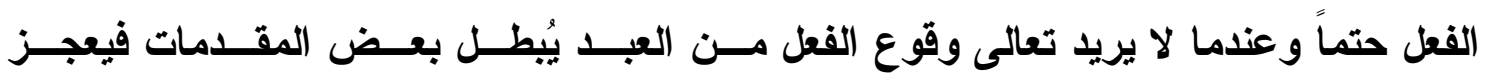

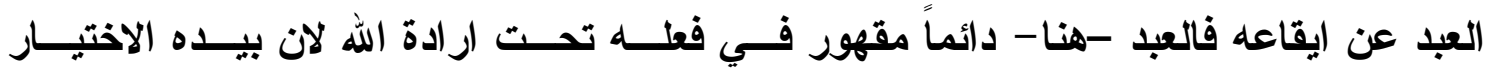

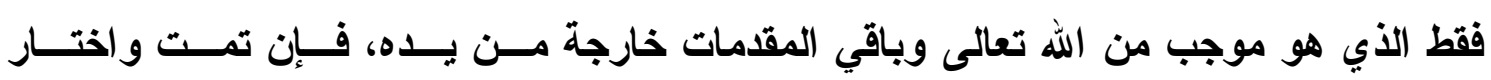

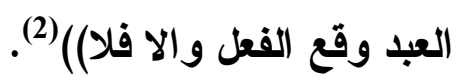

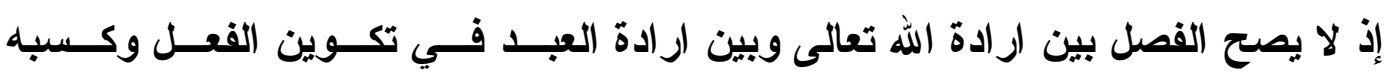

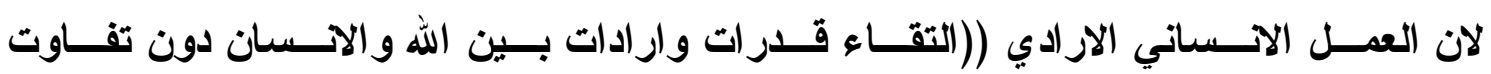

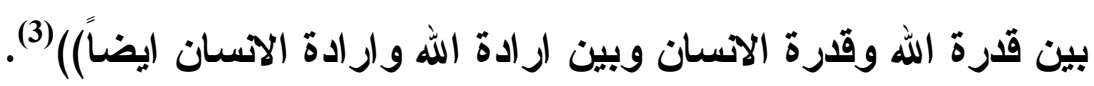

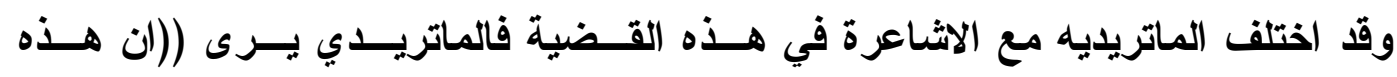

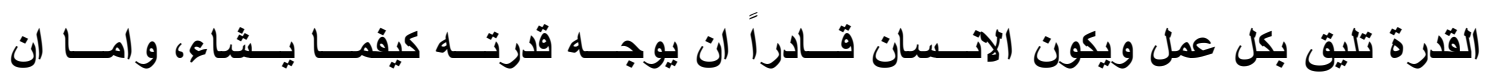

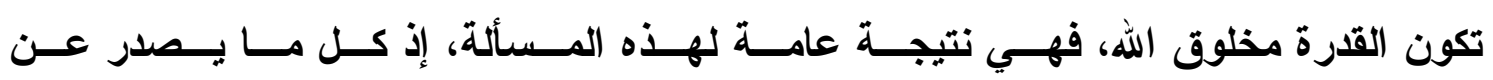

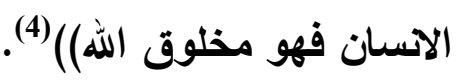

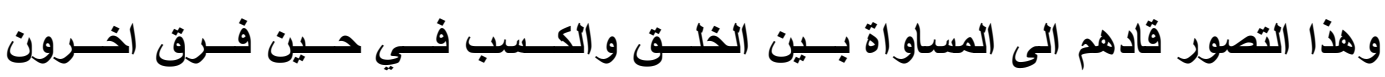

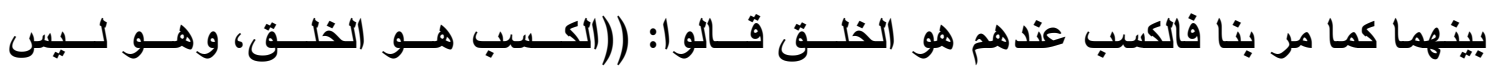

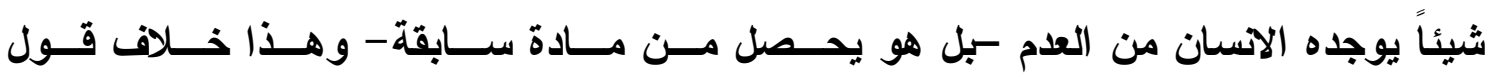

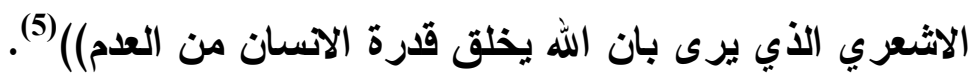

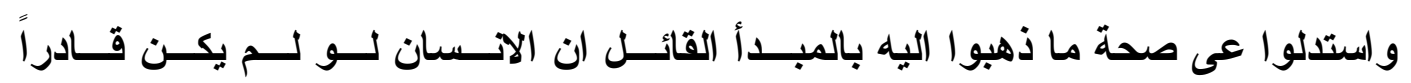

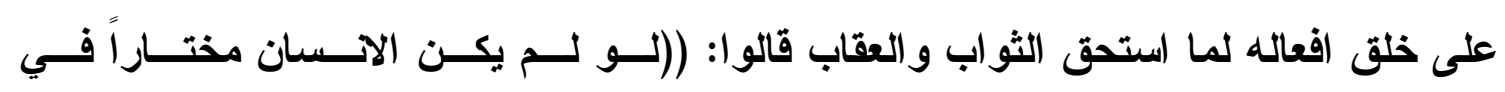

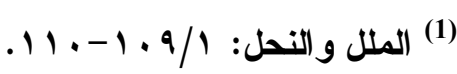

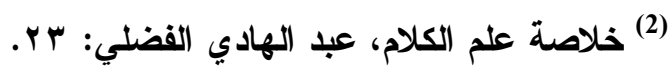

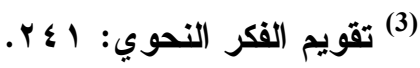

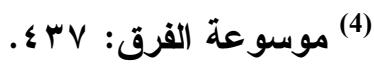

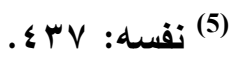





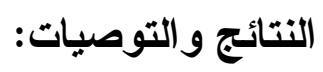

توصل البحث الى جملة من النتائج و التوصيات منها:

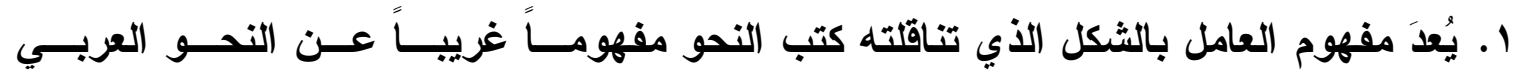

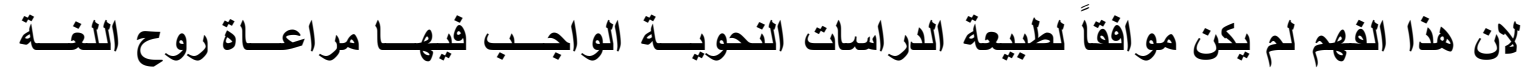
وطبيعة الناطقين بها.

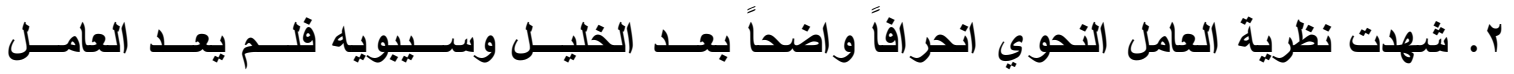

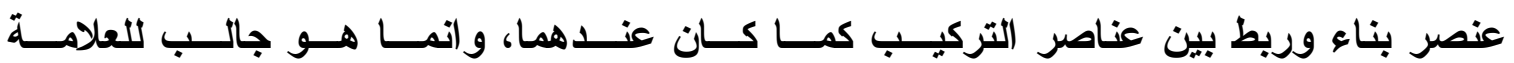
الاعر ابية بل الخالق لها كما فهم ذلك بعض النحاة.

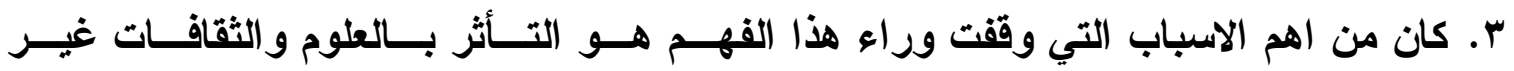

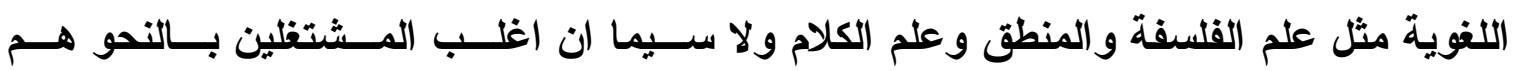
من المناطقة و الفلاسفة و المتكلمين.

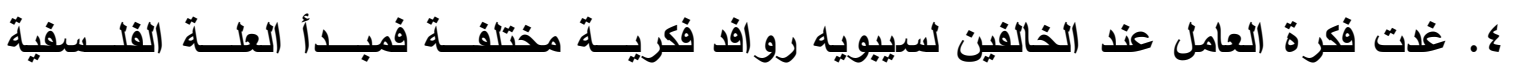

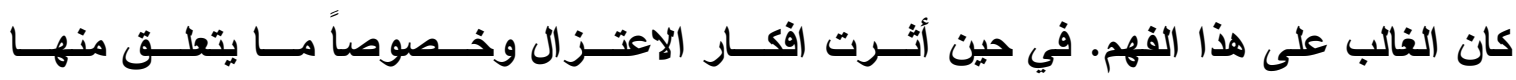

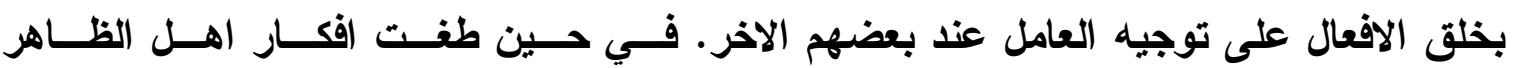
على من قال بالعامل التوفيقي.

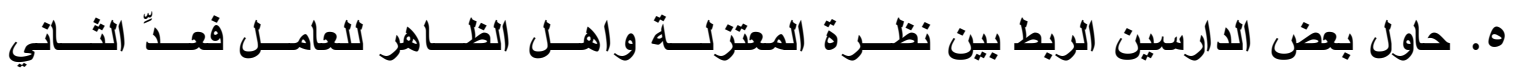

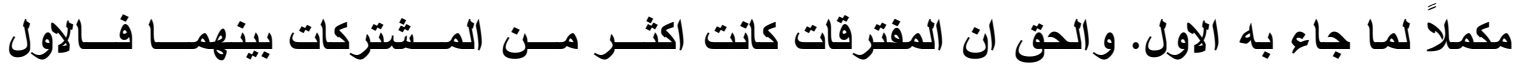

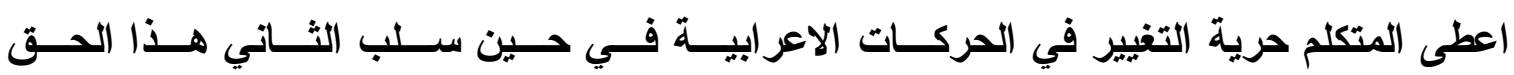
وجعله مقتصراً على ذات الله سبحانه.

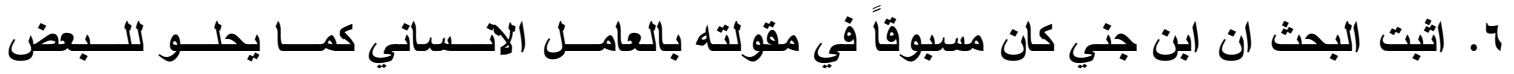

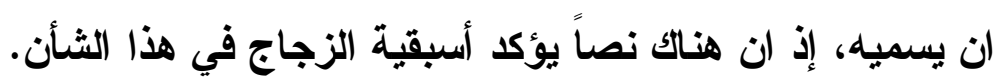

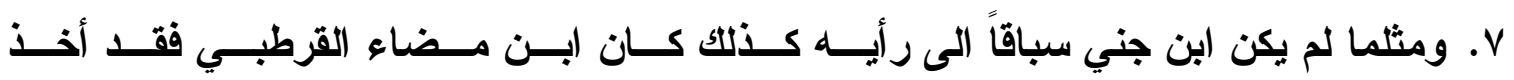

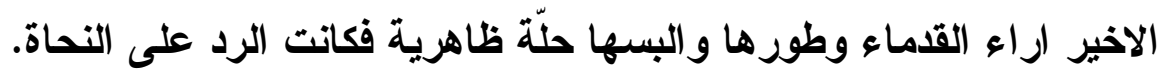

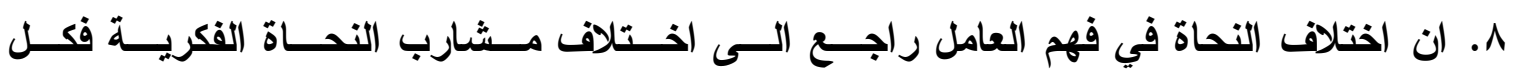

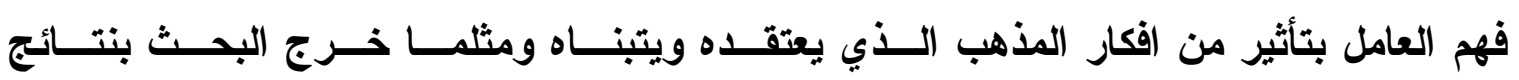

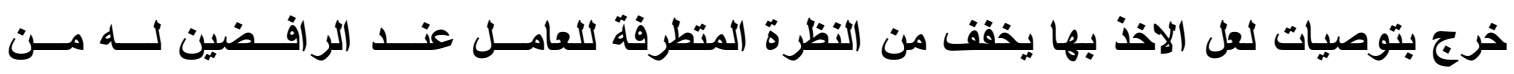




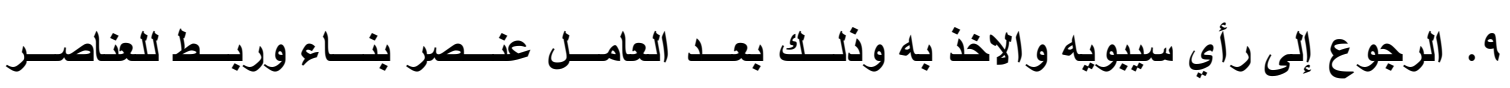

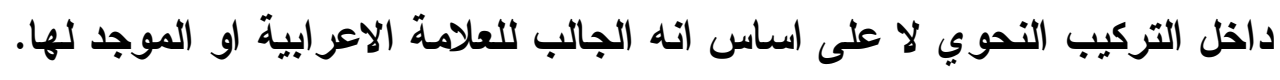

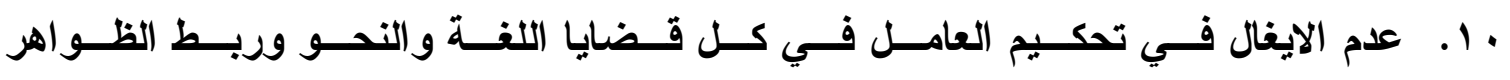

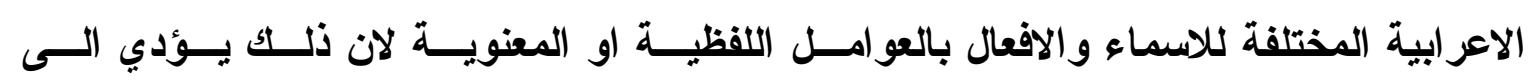
كثرة التأويل و الحذف بما لا يتو افقى و المعنى المقصود.

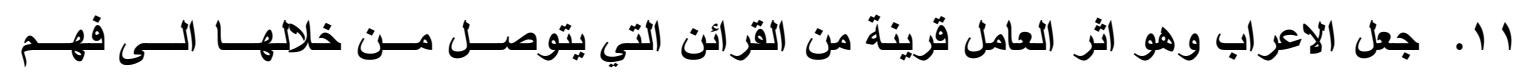

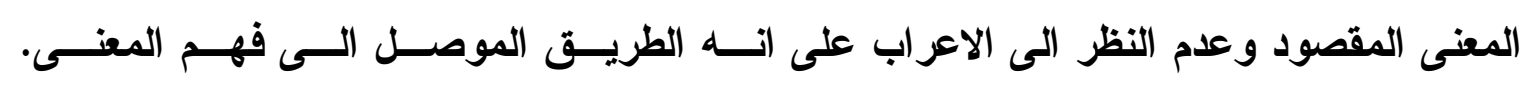
لاهه في بعض المواضع يترخص بالاعراب عند ظهور المعنى وآمن اللبس.

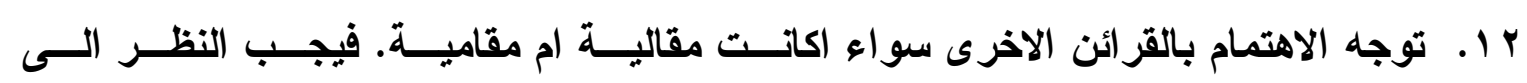

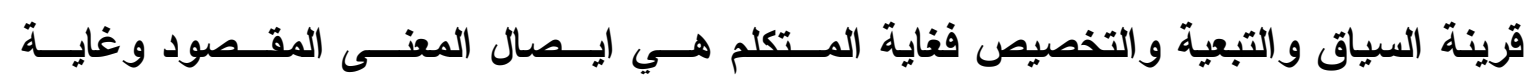

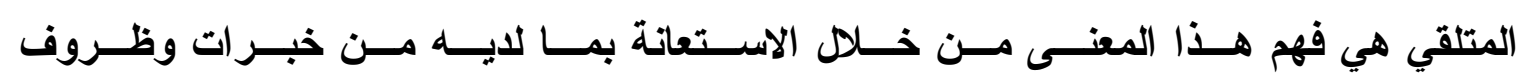
وملابسات صاحبت النص.

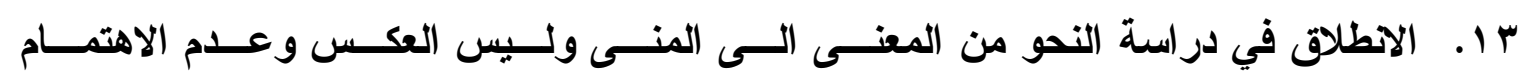

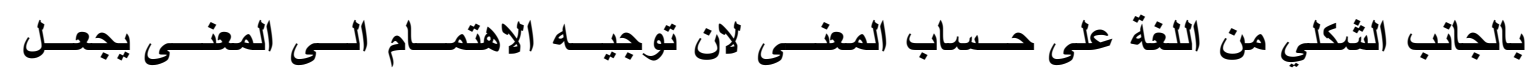
عملية التعلم ايسر من المنهج القائم على فكرة الاعراب و العامل. 
In the name of Allah,the Most Merciful, the Most Gracious. Peace and Blessings on his Prophet and his Progeng. Reading the Origins of the Grammatical Terms// Al-9aamil/ as an Example Similar to all types of knowledge that spread in Arabic, Grammar was infuenced by different sciences outside it: like philosophy, the oligy, and logic. This is related to different reasons, mainly the fact that the intellectual production whateoer is it results from action and environment which made those who work in certair field work at other fields as well.

Thus, these different fields of knowledye influenced the terms, divisions and categories of Arabic Grammar. This research investigates one of these origins that dominated/ Al-9aamil/ and/ Al-

Ma9muul/ that follows it. Different grammarians looked at/ Al9aamil/ differently; some presented it form a pure linguistic point of view, others presented it in the light of certain philosophic influences.

In the last way, they limited the meaning of/ Al-9aamil/ to the use of presenting the Ultimate, Ala'ah who directs all other action and from this stemed words.

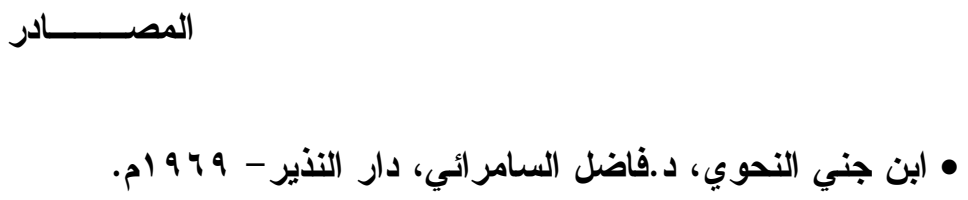


• ابن مضاء القرطبي في الميزان. د. عائد كـريم الحريـزي. مجلــة كليـة الــــعوة الاســلامية/ العـدـد الـسـابع عشر.

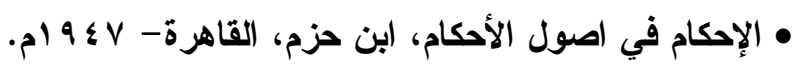

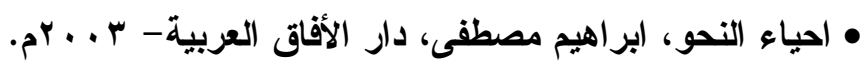

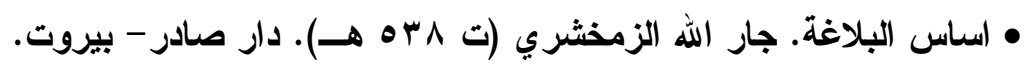

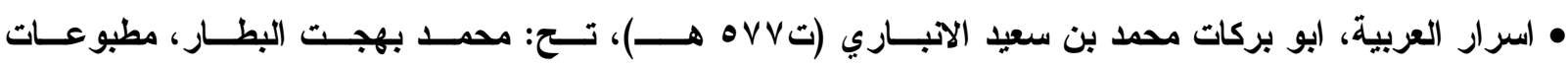
المجمع العلمي دمثق.

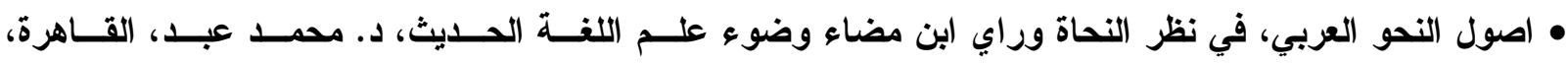

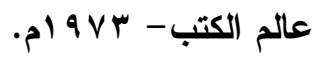
• الأصاف في مسائل الخلاف بين البصريين والكوفيين، الآباري، دار احياء التراث العربي. • البحث اللغوي عند العرب، احمد مختار عمر، عالم الكتب - القاهرة، الطبعة السادسة.

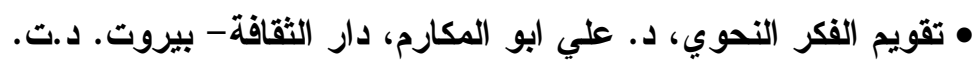

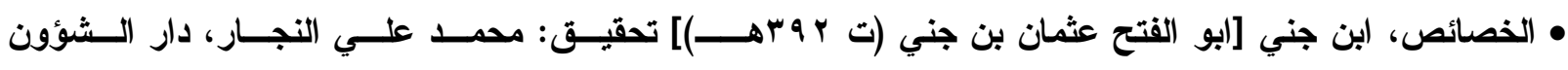

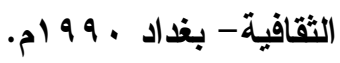

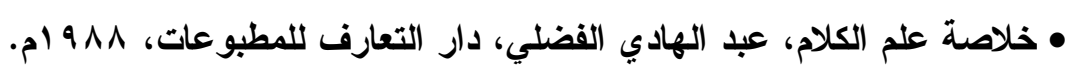

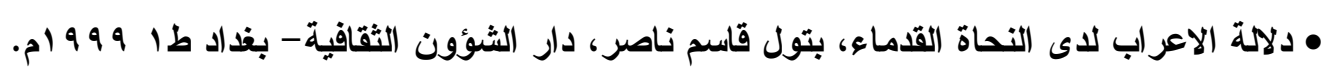
• الرد على النحاة ابن مضاء القرطبي، تح: د. شوقي ضيق، دار الإد المعارف.

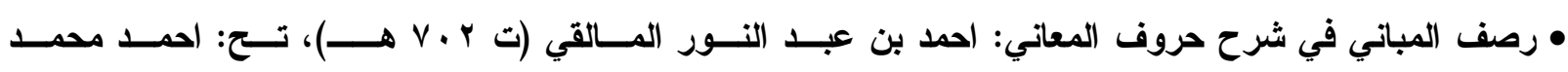

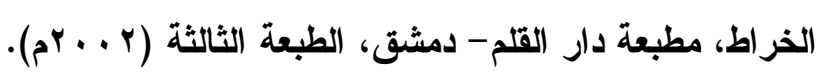

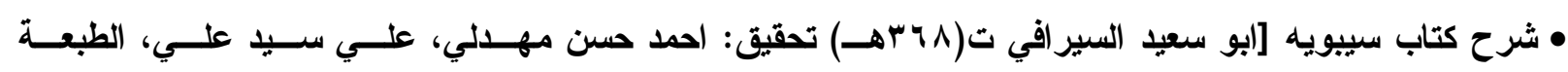

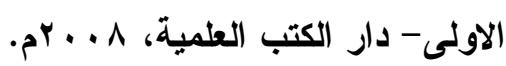

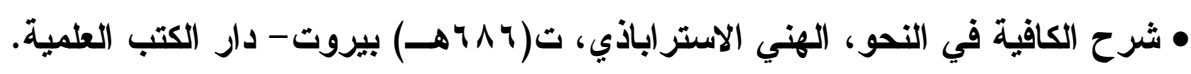

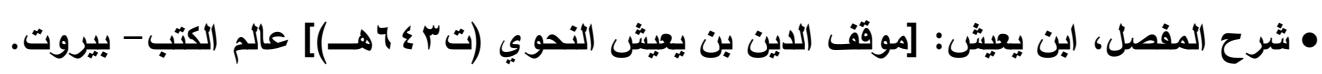

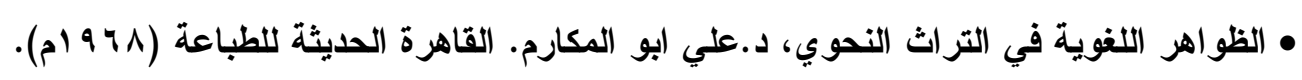

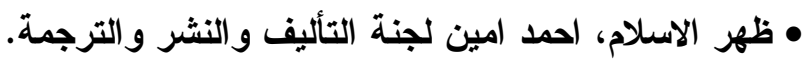
• العلامة الاعر ابية في الجملة بين القديم والحديث، د. محمد حماسة عبد اللطيف، دار غريب.

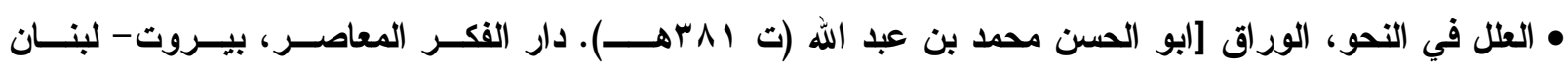
دار الفكر دمشث - سوريا.

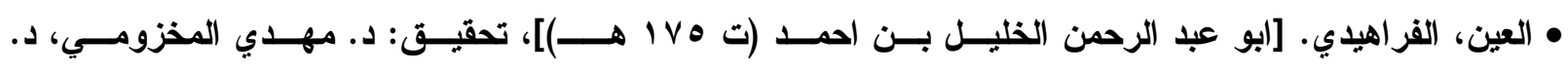

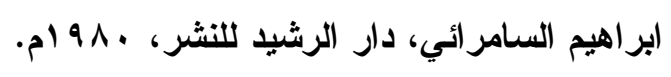

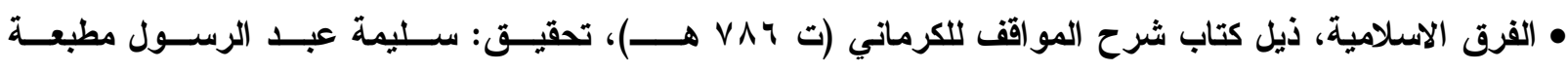

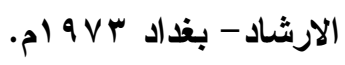

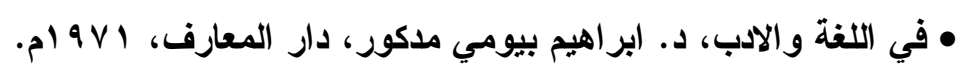


• قضايا نحوية. د. مهدي المخزومي، المجمع الثقافي ابو ظبي- الامارات.

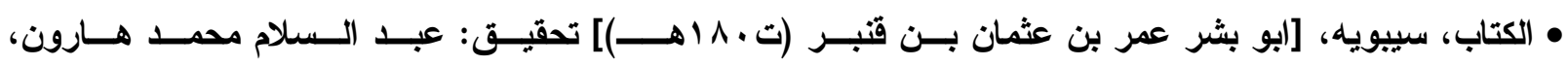

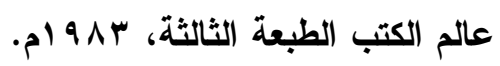

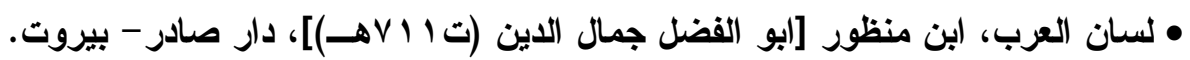

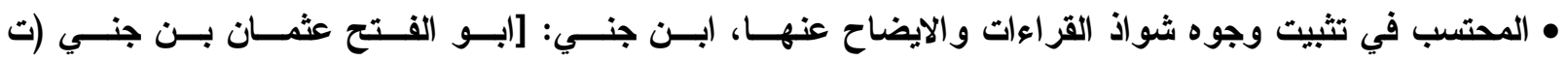

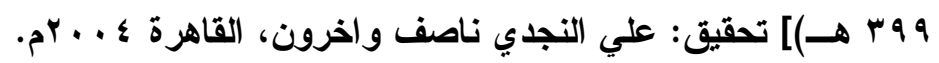

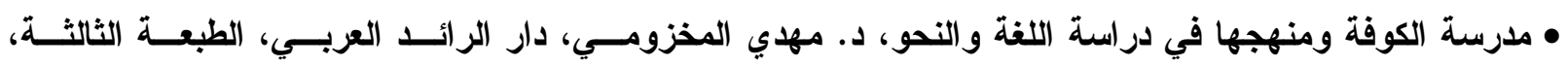
. $19 \wedge 7$

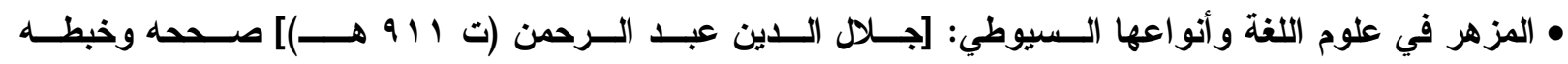
فؤاد علي منصور، دار الكتب العلمية بيروت - لبنان.

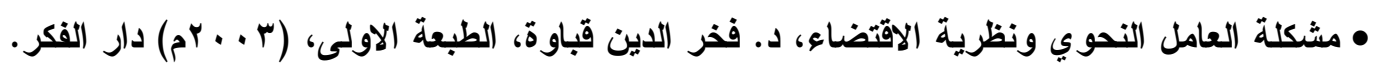

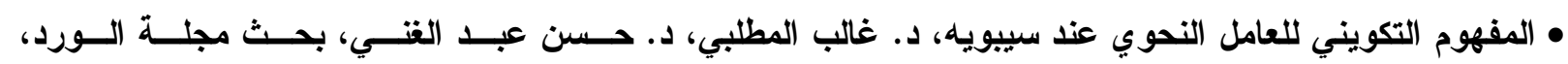

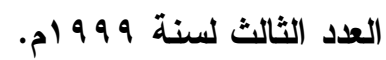

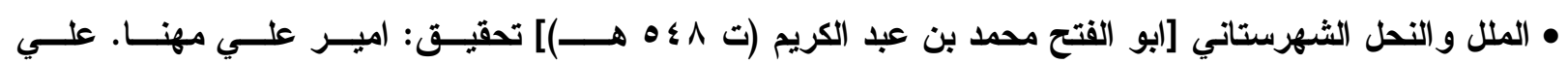

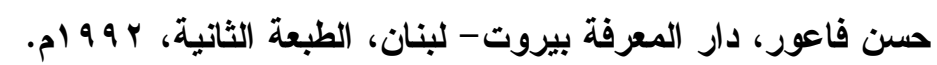

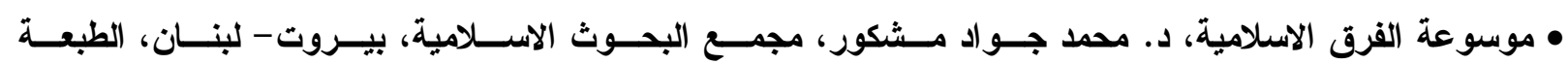

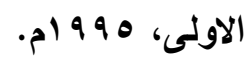

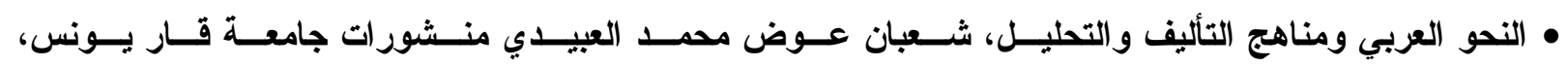
. 1919

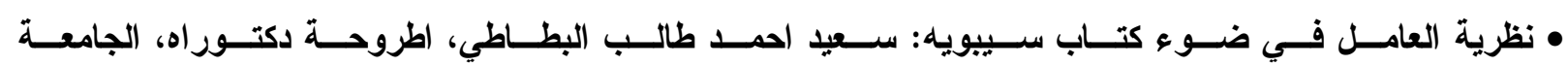

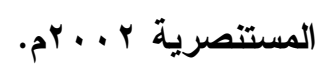

